\title{
İkinci Dünya Savaşı’nda Kıyı ve İç Hat Savunması: Çakmak Hattı (Büyükçekmece-Çatalca) Koruganları
}

\author{
Coastal and Internal Defence during World War Two: \\ Blockhouses of Çakmak Line \\ (Büyükçekmece - Çatalca)
}

\section{Salim AYDIN}

\begin{abstract}
$\ddot{\boldsymbol{O}} \boldsymbol{z}$
Koruganlar, bir saldırı esnasında kendi bölgesini özellikle tank ve uçak bombardımanına karşı korumaya çalışan savunma yapılarıdır. Bu dayanıklı siğınaklar yüzyıllardır devam eden savaş stratejisinin ve teknolojisinin bir sonucudur. Koruganlarin ana malzemesini demir ve beton oluşturmaktadır. Sanayi Devrimi'nden sonra teknoloji oldukça ilerlemiş İkinci Dünya Savaşı öncesinde uçakların ve tankların daha çok ön plana çıkmastyla koruganların önemi iyice artmıştır. Bu yapılar, Dünya'da ilk defa 1904 yılında Rus-Japon Savaşı'nda Ruslar tarafindan kullanilmuştır. Koruganlara, Avrupa'da blockhouse, pillbox, bunker, Türkiye'de ise "korugan" adı verilmiştir. Avrupa'da özellikle de Fransa'da, İkinci Dünya Savaşı öncesinde savunma stratejisi olarak koruganlar yapılmaya başlanmıştır. Özellikle Türkiye'de, bahsi geçen Avrupa'nın bu savunma stratejisi politikasını uygulamıştır. Dönemin Genelkurmay Başkanı Fevzi Çakmak'ın talimatıyla koruganlar Marmara Bölgesinin stratejik öneme sahip noktaları ile Batı Anadolu'nun kıyı
\end{abstract}

\footnotetext{
* Dr. Öğretim Üyesi, Milli Savunma Üniversitesi Fatih Harp Tarihi Araştırmaları Enstitüsü, ORCID: 0000-0002-2717-4938, e-posta: saydin4@msu.edu.tr.

Makalede kullanılan bütün fotoğraflar yazar tarafından çekilmiş ve yazara aittir.

Geliş Tarihi / Submitted : 18.03.2020

Kabul Tarihi / Accepted : 20.04.2020
}

383

Güvenlik Stratejileri

Cilt: 16

Sayı: 34 
Salim AYDIN

384

Güvenlik Stratejileri

Cilt: 16

Sayı: 34

şeridinde bazı noktalara yapılmıştır. Çakmak Hattı adı verilen koruganların en yoğun yapıldiğ̀ yer, Osmanlı Devleti'nin son döneminde İstanbul'u korumak maksadiyla oluşturulan Çatalca Hattı ile ayn bölgededir. "Çakmak Hattı", Büyükçekmece Gölü ile Terkos (Durusu) Gölü’nün doğusu, bunların arasında kalan bölgeyi kapsamaktadır. Çakmak Hattı'nda büyüklügüne ve kullanım amacına göre yaklaşı on farkl tipte korugan tespit edilmiştir. Türkiye'de İkinci Dünya Savaşı tehlikesinin geçmesi üzerine koruganlar kaderine terkedilmiştir. Bu çalışmada, kaderine terkedilen koruganlar ele alınmakta ve tarihi mirası yaşatmak için nelerin yapılabileceğini değerlendirilmektedir.

Anahtar Kelimeler: Askerî Tahkimat, Korugan, Majino Hattı, Çakmak Hattı, Mareşal Fevzi Çakmak.

\section{Abstract}

Blockhouses are defensive structures that are built to protect the region thereof particularly against the bombardments of tanks and planes during a raid. The blockhouses were actually a result of the war strategy and technology that had been ongoing for centuries. The basic components of these durable strongholds were iron and concrete. Following the Industrial Revolution, the remarkable development in technology and the extensive use of warplanes and tanks prior to World War II had noticeably increased the significance of blockhouses. These structures were first used in the world in 1904 by Russians during the Russian-Japanese War. The blockhouses are known as pillboxes, bunkers, etc. in Europe and Korugans in Turkey. In Europe, especially in France, blockhouses began to be constructed as part of the defense strategy before World War II, which mentioned defense strategy of Europe was implemented, particularly, by Turkey. With the instructions of the then Chief of General Staff, Fevzi Çakmak, blockhouses were erected on those points of strategic importance in the Region of Marmara as well as on certain coastal spots of the Western Anatolia. The place where the blockhouses, known as Çakmak Line, were most intensively built was in the same region with the Çatalca Line, which was formed during the last period of the Ottoman State in order to protect Istanbul. The "Çakmak 
İkinci Dünya Savaşı'nda Kıyı ve İç Hat Savunması:

Çakmak Hattı (Büyükçekmece-Çatalca) Koruganları

Line" covers the area on the east of Büyükçekmece Lake and Terkos (Durusu) Lake and the area between the mentioned two places. About ten different types of blockhouses have been determined along the Çakmak Line by the sizes and intended uses thereof. Upon the termination of the peril of World War II in Turkey, the blockhouses were left to their fate. To summarize, this article deals with the mentioned blockhouses that have been left to their fate and suggests what could be done to conserve this historical heritage.

Keywords: Fortification, Blockhouse, Pillbox, Bunker, Maginot Line, Çakmak Line, Marshal Fevzi Çakmak.

\section{Giriş}

Avrupa'da blockhouse, pillbox, bunker, Türkiye'de "korugan" ismi verilen ve genellikle demir ve betondan yapılmış, toprak seviyesinin hem üstünde hem de altında bulunan, bu dayanıklı savunma sığınakları dörtgen, çokgen ve daire şeklinde olmakla beraber çatıları genellikle düzdür. Koruganların Dünya'da ve Avrupa'da birbirinden çok farklı tipleri vardır. Bulundukları stratejik noktaya göre büyüklükleri değişmektedir. Savaş teknolojisinin gelişmesi, özellikle seri tankların üretilmesi, tahrip gücü yüksek ve uzun menzilli topların kullanılmaya başlanması ve savaş uçaklarının etkinliğinin artmasıyla İkinci Dünya Savaşı öncesi koruganların önemi iyice artmıştır.

$\mathrm{Bu}$ dayanaklı yapılar ilk olarak Ruslar tarafindan yapılmış ve 1904 yılında Rus-Japon Savaşı'nda kullanılmıştır. Birinci Dünya Savaşı esnasında Almanlar da benzeri istihkâmlar inşa ederken, İkinci Dünya Savaş1 öncesinde Fransa ve İngiltere'de bu yapılar kendini göstermeye başladılar. ${ }^{1}$ Hollanda, Belçika, Rusya, ${ }^{2}$ Solomon-Marshall-

\footnotetext{
${ }^{1}$ James Alexander West, An Object Biography of WW2 Pillboxes in Cumbria and Lancashire and the Defensive Structures of Point edu Hoc, Normandy, France, Central Lancashire Üniversitesi Yüksek Lisans Tezi, March 2013, s. 14-15., Galler'de 20. yüzyılda yapılan askerî yapılarla ilgili bir çalışma yapılmış, koruganların korunması ve bu günün şartlarında nasıl kullanıldığı örneklerle gösterilmiștir. Bakınız. Protecting Twentieth-Century Military Structures in Wales 49 TH Annual Report
}

\section{5}

Güvenlik Stratejileri

Cilt: 16

Say1: 34 
386

Güvenlik Stratejileri

Cilt: 16

Sayı: 34

Mariana Adalarında, Filipinler'de ${ }^{3}$, Singapur'da, ${ }^{4}$ Pasifik Okyanusu'nun hem Amerika Birleşik Devletleri kıyıları hem de Japon adalarında da anılan dönemde koruganlar inşa edilmiştir. ${ }^{5}$ Kuzey İrlanda'da 22 farklı korugan tipi tespit edilmiştir. ${ }^{6}$ Avrupa'da en fazla korugan olan ülkelerden Birleşik Krallık'ta İkinci Dünya Savaşı öncesi ve esnasında yapılan korugan sayısı yaklaşık 28.000 idi. Bu sayı 2007 y1lı itibarıyla 8.000 civarına düşmüştür ki, bunların da 1.000 tanesi iyi durumdadır. ${ }^{7}$ Ayrıca koruganlara ek olarak, İngiltere'de demiryolunu tanklardan korumak için rayların her iki tarafına ejderdişleri de (anti-tank cubes) yapılmıştır. ${ }^{8}$ Ejderdişleri, genellikle çok stratejik bölgelerde ve geçiş noktalarında koruganların ön taraflarına yapılmıştır. Ejderdişleri, koruganların bütünlügünü sağlamakla kalmamış aynı zamanda koruganlara zaman kazandırmak açısından da önemli rol oynamıştır. Ejderdişlerinin de koruganlarda olduğu gibi farklı tipleri vardır.

\section{Majino (Maginot) Hattının İnşası}

Avrupa'da koruganların yoğun bulunduğu ülkelerden birisi de Fransa'dır. Zikredilen ülkede koruganlar, 1927 yılında inşa edilmeye

2002-03, Ancient Monuments Board for Wales, Cardiff 2003, s. 1-24.

${ }^{2}$ Ek 1. Rusya St. Petersburg şehir merkezine yaklaşık 15 kilometre uzaklıktaki korugan Temmuz 2015'de Salim Aydın tarafından çekilmiştir.

${ }^{3}$ The War Againist Japan U.S. Army in World War II. Pictorial Record, Editör: Kent Roberts Greenfield, U.S. Government Printing Office, Washington D.C., 2001, s. 141, 229, 246, 321.

${ }^{4}$ Singapore in World War II A Heritace Trail, National Heritage Board In January 2013, s. 17.

5 Deniz Aslan, "Özellikle Büyükçekmece Koruganları," Betonart Dergisi, İstanbul, Sonbahar 2004, s. 55-57.

${ }^{6}$ June Welsh- Carly Cooper- Randal Scott, Survey of World War II. Pillbox, Murlough, Country Down, Survey Report No: 34, Ulster Archaeological Society c/o School of Natural and Built Environment The Queen's University of Belfast, Belfast 2017, s. 1216. Kırılmış koruganların dahi ölçümleri yapılarak krokileri yayınlanmıştır.

${ }^{7}$ Alan Strickland, The Stroudwater Pillboxes: A Review of the WWII Pillboxes Along the Stroudwater Canal, Project S04, Issue 1, March 2007, s. 25.

${ }^{8}$ Robert Liddiard and David Sims, "A Guide To Second World War Archaeology in Suffolk Guide 4: Stop Lines”, Barnwell Print Ltd., England 2014, s. 24. 
İkinci Dünya Savaşı'nda Kıyı ve İç Hat Savunması:

Çakmak Hattı (Büyükçekmece-Çatalca) Koruganları

başlanmıştır. Bunların Fransa'da yapılma nedeni, Fransa'yı, Almanya'ya karş1 korumaktır. Söz konusu savunma hattı ismini, 1916 Verdun Muharebesi $^{9}$ gazilerinden ve Fransa'da 1929 y1linda Genelkurmay başkanı olan Andre Maginot'dan almıştır. ${ }^{10}$ Fransa'nın Majino Hattı'nı inşaya başlamasıyla, Almanya ile Fransa arasında sınır görevi gören Ren (Rhin) Nehri'nin karşına Almanlar acilen Siegfried Hattı'nı inşa etmeye başlamışlardır. ${ }^{11}$

Majino Hattı Fransa ile Almanya arasında, İsviçre ve Belçika sınırlarını da ihtiva eden yaklaşık 300 kilometrelik uzunluğa sahip olacaktı. Ancak bu hattın Belçika sınırı, muhtemelen işçi yetersizliğinden dolayı, tam olarak tamamlanamadı. ${ }^{12}$ Böylece Belçika sınırı savunmasız

\footnotetext{
${ }^{9}$ Michael S. Neiberg, Dünya Tarihinde Savaş, çev. Mehmet Tanju Akad, Tarih Vakfı Yurt Yay. İstanbul 2011, s. 136.

${ }^{10}$ Türkiye'de İkinci Dünya Savaşı esnasında Genelkurmay Başkanı olan Mareşal Fevzi Çakmak döneminde yapılan koruganlara da "Çakmak Hattı" adı verilmiştir.

${ }^{11}$ Hamdi Turgay, "Majino, 'Majino Hattı'nın Cephesi Üzerinde ve Derinlikleri İçinde", Askerî Mecmua, Say1: 113, Haziran 1939, s. 553-564. Bu makale Fransa'da yayımlanan Illustration gazetesinde, askerler tarafindan Majino Hattı'nda gezdirilen bir gazetecinin makalesinden nakledilmiştir. Majino Hattı'na karşı Siegfried Hattı'nın yapımının tamamlanacağı Hitler tarafindan Nürenberg nutkunda ifade edilmiştir. Hitlerin beyanatına göre Siegfried Hattı 17.000 tesisten az olmayacaktır. Hitlerin talimatıyla Almanlar, Hollanda, Belçika ve Fransa sınırlarına Siegfried hatıını yapımına başlamıştır. Bu tahkimatlar derinliğine üç-dört hat olacak ve genişlikleri $20-30 \mathrm{~km}$. bulabilecekti. Bu hat üzerinde 360.000 işçi, 100.000 muvazzaf amele kıtası, istihkâm alayları ve piyade tümenleri Siegfried Hattını bitirmek için çalışmaya başladı. Hat için günde ortalama 6000-8000 vagon tahkimat malzemesi taşınmakta, günlük çakıl sarfiyatı 100.000 tonu geçmekteydi. Siegfried Hattı'nın derinliğine doğru kademeli yapılmasının nedeni; Almanların Birinci Dünya Savaşı'nda edindikleri deneyimin sonucuydu. Hitlerin Siegfried Hattı düşüncesinde Albay Lossberg ve Ludendorff etkili olmuştu. Almanların tahkimat sistemi Majino Hattı'na göre daha üstündü. Nedeni; Majino Hattı'nda çok büyük tesisler yapılmış ve hiç hareket etmeyen, yerinde sabit duran bir müdafaa sistemine dayanmaktaydı. Siegfried Hattı ise böyle değildir. $\mathrm{Bu}$ hat üzerinde irili ufaklı koruganlar kademe kademe serpiştirilmiş ve birbirlerine destekler şekilde inşa edilmiş̧lerdir. Bkz. Muammer Yalçıner, "Sigfrit (Siegfried) Hattı", Askerî Mecmua, Say1: 137, Haziran 1945, s. 72-78.

${ }^{12}$ G. Von Ludwing, "Maginot Hattının İnşasına Dair Mütalaalar", çeviren: Arif Bilen, Askerî Mecmua, Say1: 120, Mart 1941, s. 82-91.
} 
388

Güvenlik Stratejileri

Cilt: 16

Sayı: 34

bırakıldı. ${ }^{13} \mathrm{Bu}$ hat aynı zamanda Fransa'nın bütün kuzey sınırını da kapsamiyordu. ${ }^{14}$

Majino Hattı'nın ön tarafında tel örgü şebekeleri, bunların hemen arkasında toprağa derin çakılmış altı sıra halinde düzenlenmiş ejderdişleri $^{15}$ (ray demirleri), daha geride ise üzerleri genellikle toprakla örtülmüş tabyalar (korugan) bulunmaktadır. Bu hat, FransaAlmanya sınırının 7-10 km. gerisinde oluşturulmuş arazi şartlarından yani tepe ve vadilerden yararlanılarak, hatta lojistik destek sağlayan demiryollarının güvenliği de sağlanmaya çalışılmıştır. ${ }^{16}$

Aslında, Romalılar döneminden itibaren bu bölgede kaleler, şatolar yapılarak güçlü savunma hatları oluşturulmaya çalışılmış, ancak bu kale ve şatoların birbirleriyle irtibatsız ve bağlantısız olmaları savunmayı güçleştirmiştir. Ancak 16. yüzyılda topların kullanılmaya başlanmasıyla savunma stratejileri değişmeye başlamıştır. Toplara daha dayanıklı müstahkem mevkiler ve tabyalar yapılmaya başlanmış, bununla birlikte "kazamat" ve tankların kullanılmaya başlanmasıyla, koruganlar İkinci Dünya Savaşı öncesinde Avrupa'da bir savunma stratejisi olarak tercih edilmiştir.

Majino Hattı'nın oluşturulmasının bir sebebi de Birinci Dünya Savaşı'nda alınan derslerdir. Bu savaş öncesinde Fransa bütün tahkimatını Almanya sınırına yapmış, ancak Almanlar bundan haberdar olunca, tahkimatın yapıldığı bölgeden değil de Belçika üzerinden Fransa'ya girmiştir. Almanların 380, 400 ve $420 \mathrm{~mm}$. çaplı obüsleri, söz konusu tahkimatı yerle bir etmiş, beton ve demirden yapılan kulelerin önemi

${ }^{13}$ Michael S. Neiberg, a.g.e., s.136.

14 Donald Sommerville, Resimli Harp Tarihi II. Dünya Savaşı, çev: Ali Önsan, Türkiye İş Bankası Kültür Yay., 2012, s. 23.

${ }^{15}$ Ejderdişleri genellikle betondan ve ray demirlerinden yapılmıştır. Çatalca'daki Çakmak Hattı'nda betondan yapılmış ejderdişlerinin üzerine ray demirleri de eklenmiştir. Bkz. Ek 2.

${ }^{16}$ Hamdi Turgay, a.g.m., s. 554.

${ }^{17}$ Fransızca Casemate kelimesinden gelmektedir. Barınmak, topları mermilerden korumak ve cephaneyi depo etmek maksadıyla kullanılan gömme siper, küçük tahkimli tesis. 
İkinci Dünya Savaşı'nda Kıyı ve İç Hat Savunması:

Çakmak Hattı (Büyükçekmece-Çatalca) Koruganları

daha çok ortaya çıkmıştır. ${ }^{18}$ İkinci Dünya Savaşı öncesinde bu yüzden yeni bir savunma konsepti olarak blockhouse (korugan) ve toprak altında yapılan sığınaklardan oluşan istihkâmların önemi anlaşılmıştır.

Fransa'da yer altı koruganlarının yapımına 1927 yılında başlanmış; 1928 yılında üç mıntıkada koruganlar inşa edilmiştir. 1929 yılında Majino Hattı iyice oluşmaya başlamıştır. Oluşturulan ilk bütçe için yaklaşık 2.900.000.000 Frank gerekmekteydi. Bunun için dört y1llık vadeli bir kredi tahsis edilmişti. Ren Nehri boyunca $150 \mathrm{~km}$ 'lik Almanya-Fransa hududunu ve yaklaşık $160 \mathrm{~km}$. Belçika sınırını ihtiva eden bu hat, ${ }^{19}$ İkinci Dünya Savaşı esnasında beklenen görevini yerine getiremedi. ${ }^{20}$ Fransa, savaş başlamadan önce koruganların yapımını tamamlayamamış bu yüzden tahkimatta tam yapılamamış; Almanlar da Majino Hattı'nın askerî açıdan en zayıf olduğu ve yoğun ormanların bulunduğu Ardenler (Ardennes) gibi sürpriz bir yerden taarruzu gerçekleştirmişti. ${ }^{21}$ Böylece Fransa kolayca işgal edilmişti. ${ }^{22}$

Stratejik bir savunma hattı olarak yapılan Majino Hatt1 üzerinde demiryolu, malzeme depoları ve askerî ordugâhlar da kurulmuştu. Bu tesislerin hepsi aynı büyüklükte değildi. Hat üzerinde toprak seviyesindeki koruganların en küçüğüne makinalı tüfek (mitralyöz)

\footnotetext{
${ }^{18}$ Turgay, a.g.m, s., 556.

${ }^{19}$ A.e., s. 556. Bazı kaynaklarda ilk bütçe ile ilgili birbirine yakın rakamlar verilmiştir. Örneğin; John Keegan, Majino Hattı için ilk bütçenin 3 milyar Frank olduğunu söyler. Bkz. John Keegan, İkinci Dünya Savaşı, Çev. Samet Öksüz, Say Yay., İstanbul 2016, s. 69.

${ }^{20}$ F. Kalfaoğlu, "Fransa Harbi" (Bu makale Fransızcadan tercüme edilmiștir), Askerî Местиа, Sayı: 120, Mart 1941, s. 69-81. Fransa, 1939 yılında Majino Hattı'nı yapmasıyla birlikte seferberliğe hazırlandı. Fransa, İngilizlerin on tümenlik desteğiyle Belçika üzerinden bir taarruza hazırlanmak maksadıyla ordusunu Sedan ile Manş Denizi arasında topladı. Böylece Majino Hattı'nın tahkimatı eksik kaldı. Fransa stratejik bir hata yapmıștı.

${ }^{21}$ İlkin Başar Özal, Kısa İkinci Dünya Savaşı Tarihi, Timaş Yayınları, İstanbul 2019, s. 134. Türkiye'de yapılan bir çalışmada; Majino Hattı'na geçmenin zor olduğu düşüncesinden dolayı Almanya'nın Belçika üzerinden saldırıya geçtiği yazılmıştır. Ancak bu görüş için bir kaynak gösterilmemiştir. Bkz. Zekeriya Doğan, İkinci Dünya Savaşl ve Türkiye'nin Savaş Stratejisi, Cinius Yay., İstanbul 2016, s. 66.

${ }^{22}$ General Heinz Guderian, Bir Askerin Anıları, çev. Korgeneral (E) İhsan Gürkan, Kastaş Yayınevi, İstanbul 2018, s. 121.
}

\section{9}

Güvenlik Stratejileri

Cilt: 16

Sayı: 34 
yerleştirilebilirken, en büyük koruganlar toprak altında bulunmakta ve bunların içerisinde askerler yaşayabilmekteydi. Koruganlar, savunma

Güvenlik Stratejileri

Cilt: 16

Sayı: 34 amaçlı yapıldıkları için düşmana karşı mahfuzdur. Düşman, ancak savunma hattı içerisine girdiğinde koruganlardan askerler top ya da makinalı tüfeklerle ateşleme yapılabilmekteydi. ${ }^{23}$ Korugan ve sı ğınakların inşa edildikleri yerler de birbirlerini koruyabilecek şekilde seçilmişti. Örneğin bir korugan düşman tarafindan susturulduğunda sağındaki ve solundaki koruganlar, susturulan koruganın savunma hattına makaslama ateşleme yaparak o bölgeyi savunabilecek şekilde inşa edilmişlerdi. Ayrıca koruganlar birbirleri ile telefon yoluyla iletişim kurabiliyor, bir kısmının altında ise birbirlerini bağlayan tüneller olabiliyordu.

Koruganların farklı yerlerden cephane ve insan girişleri olmakla birlikte, bunların merkezden uzakta sessiz yerlerde gizli çıkış noktaları da bulunmaktadır. Bu koruganlarda yaklaşık yirmi metre uzunluğunda giriş tünelleri vardır. Zikredilen giriş tünellerinin sonunda bulunan asansörler vasitasıyla cephane ve erzaklar 33 metre aşağıya taşınabilmektedir. Elektrik sistemiyle aydınlatılan tünellerin uzunluğu 900 metreye kadar uzayabilmektedir. Bahsi geçen tüneller tesisin omurgasını oluşturmaktadır. Ana tünele bağlanan talî tüneller de mevcuttur. Büyük koruganların içerisinde demiryolu sistemi de vardır. ${ }^{24}$ Fransa'daki en kuvvetli koruganlar; Hochwald, kuzey Haguenau, Bitche ve Hakenberg'in kuzey doğusunda yapılmıştır. Bu koruganların derinliği 100 metreye bulabilmektedir. ${ }^{25}$

Koruganlarda uyulması gereken kurallar önemlidir. Örneğin, elektrik tesisatında kaza meydana gelmemesi için askerler silahlarını, dipçikleri yukarı gelecek şekilde baş aşağı tutarlar. Aslında bir koruganın savunulmasında tüfeklerin fazla bir etkisi yoktur. Asıl görevi toplar ve mitralyözler görmekle birlikte, tüfek yalnız mazgallardan ateş etmek için kullanılmaktadır.

${ }^{23}$ G. Von Ludwing, a.g.m., s. 89.

${ }^{24}$ Hamdi Turgay, a.g.m., s. 558-559.

${ }^{25}$ Von Ludwing, a.g.m., s. 84-85. 
İkinci Dünya Savaşı'nda Kıyı ve İç Hat Savunması:

Çakmak Hattı (Büyükçekmece-Çatalca) Koruganları

Koruganların iç duvarlarındaki demir borular önemli yer tutar. $\mathrm{Bu}$ boruların bir kısmı elektrik ve telefon tesisatı, diğer bir kısmı da hava akımı içindir. $\mathrm{Bu}$ tesislere mahalle merkezinden, $100-150 \mathrm{~km}$ uzaklıktaki bir merkezden ya da dizel dinamolardan olmak üzere üç farklı yerden elektrik verilmektedir. Koruganların içerisinde tren yolu vasıtasıyla cephane taşınabilmekte, böylelikle ikmal kolay bir şekilde sağlanabilmektedir. ${ }^{26}$

Majino Hattı'nda koruganların içerisine yüzlerce insanın yaşayabileceği odalar inşa edilmiş ve bu sığınaklara üç dört ay yetecek erzak ve cephane tedarik edilmiş, ${ }^{27}$ koruganın bütün ihtiyaçları temin edilmiştir. Koruganda her şeyin elektrikle yapıldığı mutfaklar, şarap kilerleri, etlerin korunması için soğuk hava deposu dahi bulunmaktadır. Yine koruganlarda yaklaşık 80 metre derinliğe sahip su kuyuları vardır. Su kuyusu bulunmayan koruganlarda havuzlar ve sarnıçlar hazırlanmıştır.

Koruganlar için hastaneler de yapılmıştır. $\mathrm{Bu}$ hastanelerin konsültasyon odaları ve ameliyathaneleri vardır. Ayrıca, subayların bütün ihtiyaçlarını karşılayabilecekleri ayrı bir daire de tesis edilmiştir. Koruganların duvarlarında rutubet olmaması ve rahat nefes alınabilmesi için havalandırma tertibatı kurulmuştur. Bu tertibatta, havayı süzerek temizleyen büyük süzgeçler ve körükler mevcuttur. Bu havalandırma sistemi sayesinde, gaz saldırısı olması durumunda, öldürücü gazların tesiri etkisiz hale getirilmektedir. Havalandırma sistemi elektrikle faaliyet göstermektedir. Bu sistem, bir kaza halinde insan kol gücüyle de çalışabilmektedir.

Majino Hattı koruganlarında, komuta merkezinin bulunduğu hücrede, diğer koruganlarla irtibat kurulacak telefon sistemi, haritaların serildiği büyük bir masa da yer almaktadır. Komuta merkezinin, yani toprak seviyesinin 33 metre altından dişarıdaki bütün hareketler periskop ile gözlenebilmektedir. Bu kadar masrafın yapıldığı ve teknolojinin kullanıldığı Majino Hattı inşa edilirken bazı teknik hataların yapıldığı

\footnotetext{
26 Turgay, a.g.m., s. 559.

${ }^{27}$ Von Ludwing, a.g.m., s. 88.
}

Güvenlik Stratejileri

Cilt: 16

Say1: 34 
392

Güvenlik Stratejileri

Cilt: 16

Sayı: 34

da görülmüştür. Örneğin sahra tahkimatının düşman saldırısına en açık arazide yoğunlaşması gerekirken Fransız kara tahkimatında bu durum tersine olmuştur. Fransızlar düşman saldırısının gerçekleşeceği arazinin tamamında değil de sadece arazinin yüksek noktalarına tahkimat yapmışlardır. Çünkü düşmanın yarma harekâtıyla savunma alanının içerisine girmesine müsaade etmişler, ani bir saldırı ile düşmanı geri atabileceklerini düşünmüşlerdi. ${ }^{28}$ Ancak Harekât Fransızların düşündüğü gibi gitmedi. Fransızlardan daha fazla tankı olan ve bu tankları çok seri hareket ettirebilen Almanları durdurmak mümkün olmadı.

Majino Hattı'ndaki koruganların en büyüklerinden birisi, çelikten yapılmış büyük bir sığınağa benzemekte ve içeride çevreyi gözetleyen bir dürbün, onun yanında 75'lik namlu ağzı bulunmaktadır. $\mathrm{Bu}$ koruganın ön tarafinda bir sahra tankını yutabilecek dik ve betondan yapılmış hendek vardır. Hendeğin ön tarafında tren raylarından yapılmış ejderdişleri ve bunların önünde de tel örgü seddi bulunmakta, bu durum $\mathrm{Z}$ şeklinde hat çizerek kilometrelerce devam etmektedir. Ancak bütün bu yapılanların yeterli olmadığı görülecek, bunların arkalarının takviye güçlerle beslenmesi gerektiği ortaya çıkacaktır. ${ }^{29}$ Ayrıca Majino Hattı'nın inşasında çok fazla para harcandığından savaş halinde kullanilacak top ve makinalı silahlara yeteri kadar harcama yapılmamıştır. ${ }^{30}$

Zikredilen koruganların yapıldığ 1 tahkimat bölgesi civarında 1500 kişinin yaşayabileceği askerî şehirler kurulmuştur. Bu şehrin girişinde pavyonların olduğu bir yol, daha sonra evli subaylar mahallesi,

${ }^{28}$ Von Ludwing, a.g.m., s. 83.

${ }^{29}$ Turgay, a.g.m., s. 561-562. Fransızların bu tahkimatları yapması, savaş başlamadan önce Almanya'da yayımlanan bazı gazetelerde "Fransızların tahkimatı kendi kuvvetlerinden evvel bizim tarafımızdan işgal edilecektir" vurgusuyla istihza konusu olmuştur.

${ }^{30}$ Von Ludwing, a.g.m., s. 85-86. 1000 tane askeri olan koruganda beş kilometre atış menzili olan beş adet 13,5'lık top, sekiz kilometre menzili olan dokuz adet 7,5'lik santimetrelik top, üç adet 8,5 santimetrelik piyade havanı, 18 adet çift makinalı tüfek vardı. Koruganların ön arazilerinde bulunan koruganlarda da top ve makinalı tüfekler bulunmakla beraber bu koruganlar 21 santimetrelik topların atışlarına dayanabilecek vaziyette yapılmıştı. Ancak bunlar yeterli değildi. 
İkinci Dünya Savaşı'nda Kıyı ve İç Hat Savunması:

Çakmak Hattı (Büyükçekmece-Çatalca) Koruganları

aileli erbaşlar mahallesi, bekâr odaları ${ }^{31}$, iki gazino, bayrak direği ve daha ileride çok modern bir şekilde yapılmış ordugâh bulunmaktaydı. Ordugâhta bilardo ve oyun salonları, bir tiyatro salonu da vard..$^{32}$ Majino Hattı'nın sadece 140 km'lik kısmı yapılabilmiş, Fransız gazetecilere zikredilen hattın tamamlanmış kısımları gezdirilmiş, bu hat üzerinde 13 tane ordugâh tesis kurulmuştur. ${ }^{33}$

Yukarıda Majino Hattı'nın yapımı ve bütün özellikleri bahsedilirken İkinci Dünya Savaşı'nın çıkma ihtimalini önceden öngeren Gazi Mustafa Kemal Atatürk, Fransızların politikalarının ve stratejilerinin hatalı olduğunu vurgulamış, Majino Hattı üzerinde durmuştur. $^{34}$ Yine Gazi Paşa, Orgeneral Fahrettin Altay'a, Majino Hattı'nın faydasına inanmadığını, savaşı insanın yaptığını, insanın da toprak üzerinde olması gerektiğini anlatmıştır. Toprak altında betondan yapılmış borularla ve zırhlı kulelerden oluşan kuvvetin, harp dışı sayılması gerektiğini ifade eden Gazi Paşa, manevra kabiliyetini kendi kendine imha eden bir ordunun harbi kaybedeceğini vurgulamıştır. ${ }^{35}$ Gazi Paşa'nın görüşlerinin ne kadar isabetli olduğu savaş esnasında ortaya çıkmıştır.

Fransa'da koruganların yapıldığı ve savaş hazırlıklarının devam ettiği süreçte nihayet beklenen İkinci Dünya Savaşı 1 Eylül 1939 tarihinde Almanya'nın Polonya'ya saldırısı ile Dünya gündemine yerleşmiştir. Batı cephesinde savaş 10 Mayıs 1940 tarihinde başlamıştır. Fransa'nın, Almanlara karşı 1 Haziran 1940 tarihi itibariyle Majino Hattı'nın da dâhil olduğu müstahkem mevki birliklerindeki yaklaşık subay sayısı 6350 yaklaşık asker sayısı ise 191,000 civarındadır. 11 Haziran'da Alman tehdidi karşısında Fransız komutanlardan Freydenberg geri çekilme kararı almış, Fransız General Prételat bu kararın doğruluğunu

\footnotetext{
${ }^{31} \mathrm{Bu}$ odalarda mutfak, kütüphane, oyun salonu bulunmaktadır.

32 Turgay, a.g.m., s. 562. Tiyatro salonunda haftada üç gün film gösterimi yapılmaktadır. Bu salon Pazar günleri ise kilise olarak kullanılmaktadır.

33 John Keegan, a.g.e., s. 69.

${ }^{34}$ Hikmet Özdemir, Savașta ve Barıșta Kemal Atatürk, Doğan Kitap, İstanbul 2019, s. 638.

${ }^{35}$ Özdemir, a.g.e., s. 620.
}

393

Güvenlik Stratejileri

Cilt: 16

Say1: 34 
Güvenlik Stratejileri

Cilt: 16

Sayı: 34

onaylamış, ${ }^{36} 18$ Haziran'a kadar süren muharebeler sonucunda Fransa, Almanya'dan anlaşma isteğinde bulunmuştur. 22 Haziran'da iki ülke arasında antlaşma imzalanmıştır. Sonuç itibariyle Almanya, Fransa'yı işgal etmiştir. Bu işgalin hızlı olmasının nedenleri:

1. Fransa'nın dâhil olduğu müttefik kuvvetlerinin aynı derecede harp ve savunma yapamamalar1,

2. Belçika ve Hollanda'nın yalnız başlarına savaşa mecbur kalmaları,

3. Almanya'nın seri tanklarla başardığı stratejik baskın ve üstünlük.

4. Almanya'nın motorlu birliklerle yaptığı saldırı karşısında Fransa'nın stratejik müdafaa tertibatının yetersizliği ${ }^{37}$

Kısacası; Fransa çok büyük masraflarla yaptığı Majino Hattı'nı istediği ölçüde kullanamamıştır. Koruganlar öngörülen vazifeyi yerine getirememişlerdir. Çünkü Almanların seri tanklarına ve motorlu birliklerine karşı, koruganlara yeteri kadar mühimmat tahkimatı yapılamamıştır. Bundaki en önemli etkenlerden birisi Fransa'nın, Birinci Dünya Savaşı'nda sonra İkinci Dünya Savaşı'na kadar silah, top ve mühimmat hususunda kendisini Almanya kadar yenileyememesiydi.

\section{2. İstanbul, Çatalca ve Büyükçekmece'de Yapılan "Çakmak Hattı” Koruganlarının İşlevleri}

İstanbul ili, Çatalca ve Büyükçekmece ilçelerinde yapılan Çakmak Hattı koruganları, ${ }^{38}$ İkinci Dünya Savaşı esnasında Türkiye'ye saldırı olması durumunda İstanbul'u korumak maksadıyla yapılmıştır. $\mathrm{Bu}$ yapılar, o dönemde Türkiye'nin Genelkurmay Başkanı Mareşal Fevzi Çakmak'ın" talimatıyla yapıldığından "Çakmak Hattı" adıyla

${ }^{36}$ Clayton Donnell, The Battle For The Maginot Line, Pen \& Sword Military Yay., South Yorkshire 2017, s. 2370.

${ }^{37}$ F. Kalfaoğlu, a.g.m., 69-70.

${ }^{38}$ Koruganların en yoğun olduğu yerler: Büyükçekmece Gölü ile Terkos Gölü arasındadır.

${ }^{39}$ Fevzi Çakmak, Türkiye Cumhuriyeti tarihinde en uzun Genelkurmay Başkanlığı yapmış komutandır. 03 Nisan 1921 - 31 Ağustos 1922 (Orgeneral) 31 Ağustos 1922-12 Ocak 1944 
İkinci Dünya Savaşı'nda Kıyı ve İç Hat Savunması:

Çakmak Hattı (Büyükçekmece-Çatalca) Koruganları

anılır olmuştur. Çatalca-Büyükçekmece hattı haricinde, KırklareliPehlivanköy-Uzunköprü ile, Türkiye'nin savaşa girme ihtimaline karşı denizden çıkarma yapılması muhtemel farklı kıyı bölgelerinde de koruganlar inşa edilmiştir. Bunların en yoğun olarak yapıldığı yerler: İstanbul'da Anadolufeneri ${ }^{40}$ ile Karasu (Sakarya), Gelibolu (Çanakkale), Foça (İzmir) gibi stratejik noktalardır.

Çatalca ve Büyükçekmece ilçelerinde yapılan Çakmak Hattı'ndaki büyük koruganların altında genellikle sığınak, girişinde ise teçhizat giriş boşluğu, kalın demirden yapılmış insan giriş kapısı vardır. ${ }^{41}$ Korugan duvarlarında boş kovan tahliye kanalları da görülmektedir. Zikredilen kanallar için koruganın dış kısmında ayrıca derin bir havuz oluşturulmuştur. Bazı büyük koruganların su kuyuları da bulunmaktadır.

Çatalca-Büyükçekmece Hattı'nda gördüğü işleve göre yaklaşık 10 farklı korugan tipi vardır. Bu koruganların bulunduğu stratejik noktaya göre ebatları değişmektedir. Bunların içerisinde göreceği işleve göre, ağır makinalı tüfekler, zırhlı vasıtalara karşı toplar, bu silahlar için yeterli derecede cephane, sis ve alev cihazları bulunmaktadır. Koruganların, savunma muharebesi esnasında dışarı ile irtibatları kesilebileceğinden içlerinde yeteri kadar iaşe maddeleri ile diğer lüzumlu malzemelerin bulunması gerekmektedir.

Tıpkı Majino Hattı'nda olduğu gibi İstanbul ili Çatalca ilçesi Çakmak Hattı koruganlarına da zehirli gazlara karşı havalandırma sistemleri yapılmıştır. Bu havalandırma sistemleri, zırhlı vasıtalara (tank) karşı topların bulunmadığı sadece makinalı tüfeklerin olduğu en küçük koruganlara yapılmamıştır. İstanbul'daki Çatalca-Büyükçekmece

(Mareşal) Bkz. Türk Harp Tarihi Derslerinde Adı Geçen Komutanlar, Harp Akademileri Komutanlığı Yay. Harp Akademileri Basımevi, İstanbul 1983, s. 267.

${ }^{40}$ Anadolufeneri koruganları ile ilgili bir çalıșma yapılmıştır. Bu çalışmada Anadolufeneri ve civarındaki farklı tipteki koruganlar tespit edilmiş bunların rölöveleri çıkarılmıştır. Koruganların ağılık noktaları, özellikleri hakkında da bilgi verilmiştir. Bkz: Mustafa Tahir Ocak / Ömer Faruk Tekin, “Anadolufeneri Koruganları”, Betonart Dergisi, Say1: 60/2019, s. 66-71.

${ }^{41}$ Deniz Aslan, a.g.m., 55-56. 
396

Güvenlik Stratejileri

Cilt: 16

Sayı: 34

Çakmak Hattı koruganlarından sadece bir tanesinde havalandırma sistemi kalmıştır.

Koruganların muharebe alanlarında sonuna kadar varlığını koruyabilmesi hedeflenmiştir. $\mathrm{Bu}$ görev içerisinde koruganlardaki silahlar, planlanmış bir program çerçevesinde ateşleme yaparlar. $\mathrm{Bu}$ kuvvetli ateşin devamlı olmasını sağlayan unsur koruganların düşman saldırısına karşı dayanıklı olmasıdır. Koruganların sağlam ve dayanıklı olması düşmanın asıl muharebe alanından geri atılmasında önemli bir etkendir.

Çatalca'daki büyük koruganlarda dayanıklı yapılmış ve düşman taarruzuna açık cephesi arazi yapısına uydurularak gizlenmeye çalışılmıştır. Bundaki gaye mevzilere taarruz edecek düşmanın keşiflerini önlemektir. ${ }^{42}$ Böylece koruganlar son ana kadar kendini hissettirmeden ve hiçbir tesire maruz kalmadan vazifesini yapma imkânı elde edecektir. Bu durum düşmanın ilk anda hazırlıksız ve plansız hareket etmesinden dolayı koruganlara bir avantaj sağlamış olacaktır. ${ }^{43}$

Belirli bir hat üzerinde mevziin derinliklerine kadar serpilmiş olan koruganlar, mevziin kilit noktası olan ve muhakkak elde bulundurulması gereken yerlere veya bu yerleri en iyi koruyabilecek noktalarda yapılmışlardır. Koruganlar, asıl muharebe hattında yanlardan ateş etmek suretiyle işlevlerini görürler. Her korugan hem kendini müdafaa edebilmeli hem de komşu koruganı koruyabilmelidir. Bu durumu yerine getiremeyen koruganın hiçbir iş yapamayacağı aşikârdır.

Muharebe meydanlarında koruganlar, seyrek olsalar bile, bir taarruz halinde saldırıda bulunanların ilk karşılaşacakları mevziilerdir. Taarruz yapanlar, savunma hattına girdiğinde, ilk önce koruganları susturmak zorunda kalacaklarından, gerek oyalama ve zayiatı azaltma

${ }^{42}$ Bkz. Ek 3. Fotoğraf ektedir. Koruganlarda düşmanın geleceği cephe ve yan tarafları koruganın çatısına kadar taşlarla doldurulmuş, bu taşların üzerine toprak dökülerek araziye uydurulmuştur. Bu durum aynı zamanda bir saldırı esnasında düşman tarafindan yapılacak top ateşi esnasında koruganda oluşabilecek zayiatı azalmak için de yapılmıştır.

${ }^{43}$ Cihat Arna, a.g.m., s. 315. 
İkinci Dünya Savaşı'nda Kıyı ve İç Hat Savunması:

Çakmak Hattı (Büyükçekmece-Çatalca) Koruganları

gerekse zaman kazandırma açısından koruganlar önemli rol oynarlar. $\mathrm{Bu}$ açıdan bakıldığında koruganlar asıl muharebe hattının önlerinde yapılmış, düşmana ilk karşı koyacak hat olarak oluşturulmuştur. Koruganlarda gizlilik esas alındığından, bu yapılar yan ateşleme sistemine göre dizayn edilmiş, bu durum koruganların cephe ve arka taraflarını zayıf bırakmıştır. Bu yüzden muharebenin sonuna kadar koruganların kendilerini müdafaa edebilmeleri, eksiklerini giderebilmeleri için yapılması gereken hususlar ise şöyle belirlenmiştir:

1. Koruganlar uçak bombardımanı ve topçu ateşine karşı dayanıklı olmalıdir.

2. Düşmanın büyük koruganlardan birini susturmak amacıyla yaptığı saldırı karşısında o koruganı koruyan diğer komşu koruganlar devreye girmeli ve bu yardım daha küçük makinalı ağır silahlar vasıtasıyla yapılmalıdır. Böylece taarruz edilen koruganın kendini müdafaa edemediği alanlar korunmuş olur. ${ }^{44}$

3. Koruganın içerisinde bulunan piyadeler, düşmana karşı korugan1 koruyabilmeli, farklı taraflara karşı yapacağı ateşlerle düşmana durdurmaya çalışmalı, gerektiğinde taarruz yapabilmelidir. ${ }^{45}$

Savunma amaçlı yapılan koruganların ele geçirilme yolları da komutanlar tarafindan tarif edilmiştir. Şöyle ki, koruganları ele geçirmek için iki yol izlenir. Birincisi koruganları tahrip için düzenlenmiş kıtaların harekâtı, ikincisi; bu harekâta ayak uyduracak piyade birliklerinin taarruzudur. Birincisini yapacak olan kıtaların silah ve teçhizatı piyade ve istihkâm birliklerinden farklılık arz eder ve bu harekât birçok farklı şart ve yöntem gerektirmektedir. Şöyle ki kıta istihkâm birliğine özel silah ve vasitalar verilmek suretiyle taarruz birliği teşkil edilir. Bu birlik şöyle oluşturulur:

\footnotetext{
${ }^{44}$ Bkz. Ek 4. Fotoğraf ektedir.

${ }^{45}$ Cihat Arna, "Koruganlar ve Daime Tahkimatıyla Takviye Edilmiş Bir Mevzie Karşı Taarruzda Koruganların Zaptı”, Askerî Mecmua, Sayı: 130, Eylül 1943, s. 314-319.
}

Güvenlik Stratejileri

Cilt: 16

Say1: 34 


\section{8}

Güvenlik Stratejileri

Cilt: 16

Sayı: 34

- Engelleri tahrip kıtas1,

- Mazgalları tahrip kitası,

- Sis kitasi,

- Himaye kitas1,

- Alev makinaları kitası,

- $\quad$ İkmal kıtası ${ }^{46}$

$\mathrm{Bu}$ şekilde oluşturulmuş bir istihkâm birliği, koruganı ele geçirmek için piyade taburları emrine takımlar halinde verilir. $\mathrm{Bu}$ takımlar muharebe planına uygun olarak hareket eder. Takımların her birine münferit görevler verilir. Genellikle ele geçirilecek korugan kendi mintıkasında en kuvvetli ve taarruza engel olacağ Takımlara muharebe görevleri bağlı bulundukları piyade tabur komutanlığ1 tarafından verilir. Takımın görevini yerine getirmesi esnasında sevk ve idare takım komutanı tarafından yapılır. Bir koruganın tek bir takım tarafından alınamayacağı anlaşıldığı zaman iki takım oluşturulur. Bu takımlar bir emir komuta altında birleştirilir.

Taarruzla görevlendirilen takım komutanı, ilk önce bulundukları mevziden korugana kadar olan araziyi ve düşman durumunu araştırır. Takım komutanı bu araştırmada, arazideki doğal engellerle düşmanın oluşturduğu engelleri, bilhassa korugan etrafinda bulunan düşman kuvveti, tertibatı, ağır silahlı mevzileri ve koruganı koruyan diğer küçük mevziler hakkında bilgi toplar. Komutan yaptığı araştırmalar sonucunda harekât planı hazırlar ve kıta komutanlarına buna göre emir verir.

Taarruza başlamadan önce uçak var ise bombardıman yapılır. Buna topçu ateşi takip eder. Topçu atışıyla koruganlara en yakın tesisler, silah mevzileri, koruganların önündeki tel örgüleri ve tahkim edilmiş piyade aksamı tahrip edilir. Taarruz vakti geldiğinde takımın muhtelif kısımları hücum mevziine yanaşmaya başlayan piyadelerle birlikte hareket ederler. $\mathrm{Bu}$ ilerleme esnasında piyade ağır silahları korugana ve civarda bulunan mukavemet yuvalarını ateş altına alarak piyadelerin

${ }^{46}$ Arna, a.g.m., s. 317. 
İkinci Dünya Savaşı'nda Kıyı ve İç Hat Savunması:

Çakmak Hattı (Büyükçekmece-Çatalca) Koruganları

ilerlemesine yardımcı olurlar. Piyade ağır makinalı tüfekleri, zırhlı vasıta toplarının yanında hatta iyi ateş eden münferit avcılar tarafından koruganın mazgallarına ateş edilir. Taarruz devam ederken uçakların bombardımana devam etmesi taarruzda büyük kolaylıklar sağlar. ${ }^{47}$

İlerleme esnasında takımın mânileri tahrip kıtasıyla, sis kıtası önde olurlar. Piyade taburunun ileri kısımları hücum mevzilerine girerken yukarıda zikredilen kıtalar tel örgülere yanaşırlar. Düşmanın şiddetli ateşi devam ettiği durumda, sis kıtaları yanında bulundurdukları sis bombalarına tel örgülerin olduğu bölgeye atarlar. Böylece karşı tarafın görerek ateş etmesi engel olunur. Bu sayede tahrip kıtası teneke tahrip bombaları ile telleri tahrip eder ve tel örgüleri keserek buradan geçiş noktaları açar. Tel örgüler açılırken korugan mazgallarının da denetim altına alınması icap eder. Teller kesilerek gedikler açıldıktan sonra başta takım komutanı olmak üzere mazgalları tahrip kıtası ve alev makinaları kıtası bu gediklerden içeri sızarak korugana yaklaşmaya başlarlar. $\mathrm{Bu}$ hareket gerektiğinde sisle örtülür. Yaklaşma korugan mazgallarından görülmeyecek yönlerden hızlı bir şekilde olmalıdır. $\mathrm{Bu}$ durum, düşman ateşi altında zayiat vermeyi engeller. Taarruz esnasında komşu koruganlar da sis kıtaları ve topçu sis ateşiyle engellenmelidir. Yapılan ateşlerle sis perdesi sayesinde taarruz edilen korugana yaklaşmak kolaylaşır. Aynı zamanda diğer koruganlar önünde sahte faaliyetler yapılıyormuş süsü verilerek düşmanın aldatılması sağlanır. Yapılan bu işlemlerle koruganın alınması kolaylaşır.

Korugana yaklaşıldığı sırada alev makinaları fışkırttı̆̆ alevlerle mazgalları yakarak koruganın içerisine girmeyi kolaylaştırırlarken mazgalları tahrip kıtası yaklaşı iki metre uzunluğundaki atım yaylarıyla içeriye tesir etmeye çalışırlar. Bu arada el bombaları ve sis bombaları mazgallardan içeri atılarak korugan etkisiz hale getirilir. Koruganların etkisiz hale getirilmesinde alev makinalarının önemi büyüktür. $\mathrm{Bu}$ makinalar sayesinde korugan mürettebatı etkisiz hale getirilir. ${ }^{48}$

\footnotetext{
${ }^{47}$ Cihat Arna, a.g.m., s. 318.

${ }^{48}$ A.e., s. 319.
}

\section{9}

Güvenlik Stratejileri

Cilt: 16

Say1: 34 
Salim AYDIN

400

Güvenlik

Stratejileri

Cilt: 16

Sayı: 34

Yapılan bu planlar Türkiye'ye karşı bir saldırı olmadığı için teoride kalmıştır.

\section{3. Çatalca ve Büyükçekmece'de Yapılan "Çakmak Hattı" Koruganlarının Özellikleri ve Tipleri}

İkinci Dünya Savaşı öncesinde ve esnasında Çatalca, Çakmak Hattı'nda yapılan koruganları savunmak ya da etkisiz hale getirmek için yukarıda anlatıldığı gibi hazırlanan planlar Türkiye'ye saldırı olmadığı için kullanılmamıştır. İkinci Dünya Savaşı tehlikesinin geçmesi üzerine koruganlar askerî açıdan önemini yitirmişlerdir. Özellikle Büyükçekmece ve civarındaki koruganlar halkın dikkatini çekmiştir. 1970’li yıllara gelindiğinde Büyükçekmece ve civarındaki koruganlar, sazlıkların ve tarlaların içerisinde çokça bulunurken, şehirde göçlerden dolay1 nüfusun artmas1, daha sonra E5 karayolunun yapılmas1 sırasında $^{49}$ ve sonrasında koruganların bir kısmı tahrip edilmiş, bir kısmı tamamen ortadan kaldırılmış, bir kısmı da kaderine terk edilmiştir. ${ }^{50}$

${ }^{49}$ Bkz. Ek 5. Karayolu yapılırken küçük koruganlardan bir tanesi Beylikdüzü'nden Büyükçekmece'ye inen E5 karayolunun arasında kalmıştır. Yapıldığı dönemde hem Büyükçekmece Gölü’nü tepeden gören, hem de Marmara Denizi'ne hâkim bir tepede bulunan bu koruganın içerisine daha sonra hayvanlar için su yalağı yapılmıştır. $\mathrm{Bu}$ korugan şimdi yapılaşma ve yol yapım çalışmaları esnasındaki düzenlemeden dolayı ne Marmara Denizi’ni, ne de Büyükçekmece Gölü’nü görmektedir.

${ }^{50}$ Büyükçekmece Gölü doğu kıyısında bulunan iki korugan ile ilgili olarak İstanbul Teknik Üniversitesi Mimarlık Fakültesi Dekanlığınca bir çalışma yapılmıştır. Yapılan çalışmada Büyükçekmece Gölü kenarında ve şehir merkezine yakın iki simetrik korugan tespit edilmiş, bu koruganların fotoğrafları ve rölöveleri yayınlanmıştır. Her iki korugan da su baskınlarına karşı özel drenaj ve atık su tahliye sistemlerine sahiptir. Ancak bunların tahliye sistemlerinin çalışmadığı ve gölün baraj haline getirilmesiyle gölde su seviyesinin yükseldiği koruganlardan bir tanesinin alt katının tamamen su ile dolduğu tespit edilmiştir. Daha sonra, su seviyesinin düşmesiyle koruganların içerisine girilerek çalışma sistemleriyle ilgili inceleme yapılmıştır. Bahsi geçen iki korugan hâlâ durmaktadır. Bir tanesi Büyükçekmece Gölü üzerinde, Kanuni Sultan Süleyman'ın talimatıyla 1566 yılında yapılmaya başlanan, Kanuni'nin vefatı ile 1567 yılında II. Selim döneminde inşası tamamlanan köprünün birinci bölmesinin bittiği noktada yönü Marmara Denizi'ne bakan korugan, bir diğeri ise Büyükçekmece Kültür Parkı'nın tam ortasında bulunmaktadır. Bkz. Ek 6., Aslan, a.g.m., 53-67. 
İkinci Dünya Savaşı'nda Kıyı ve İç Hat Savunması:

Çakmak Hattı (Büyükçekmece-Çatalca) Koruganları

Büyükçekmece ilçesi 19 Mayıs Mahallesi Yıldız Sokak'ta bir koruganın üzerine dört katlı bina yapılmış, korugan bir nevi temel görevi görmüştür. ${ }^{51}$ Yine aynı ilçede Dizdariye Mahallesi Çınar Sokak'ta, içerisine top ve makinalı tüfek yerleştirilen büyük koruganlardan birisi günümüzde ev olarak kullanılmaktadır. ${ }^{52}$ Büyükçekmece Mezarlığı içinde ve kenarında üç tane korugan bulunmakta bunlardan bir tanesinin yönü Göle doğru, diğer ikisinin yönü ise kara tarafina bakmaktadır. Bu koruganlardan en büyüğü Stadyolu Sokağı'nda yer almakta ve depo olarak kullanılmakta, ${ }^{53}$ bir diğeri ise Gölboyu Cadde'si üzerinde mezarlık duvarını oluşturmaktadır. Bu koruganın üzerine beyaz bir bekçi kabini konmuş, sadece çatısı görünen yapının diğer tarafları toprak altında kalmıştır. ${ }^{54}$

Büyükçekmece İlçesi Marmara Denizi kenarından Karadeniz'e kadar Çakmak Hattı'nda yapılan saha çalışmalarında bizatihi 1100 civarında büyüklü küçüklü korugan tespit edilerek $^{55}$ büyük koruganlardan yaklaşık 200 tanesinin konumu belirlenmiştir. Yaklaşık 10 farklı tipte korugan tespit edilmekle beraber örneği çok olanlar dört tiptir. Çok olanların haricinde beşinci tip olarak bir tane tespit edilen tünelle birbirine bağlı olan en büyük korugan ile altıncı tip olan diğer bütün koruganlardan daha hâkim tepede yapılan iki korugan daha vardır.

Bunlardan 1. Tip büyük koruganların çevresinde, içerisinde sadece makinalı tüfek bulunan genellikle yarısı toprak altında, ateş

\footnotetext{
${ }^{51}$ Bkz. Ek 7. Fotoğraf ektedir.

${ }^{52}$ Ev olarak kullanan bu korugan Dizdariye Mahalle Muhtarlı̆ı binasının yan tarafinda bulunmakta ve Roman vatandaşlar tarafindan kullanılmaktadır. Bkz. Ek 8. Fotoğraf ektedir.

${ }^{53}$ Bkz. Ek 9. Fotoğraf ektedir.

${ }^{54}$ Bkz. Ek 10. Fotoğraf ektedir.

$55 \mathrm{Bu}$ hattaki alan çalışmaları Millî Savunma Üniversitesi Fatih Harp Tarihi Araştırmaları Enstitüsü Müdürü Doç. Dr. Gültekin Yıldız'ın talimatıyla, Dr. Öğretim Üyesi Salim Aydın'ın koordinatörlüğünde Eylül 2019 tarihi itibariyle yürütülmektedir. Çakmak Hattındaki koruganların sayısının 1100'in üzerinde olduğu tahmin edilmektedir. Bu koruganların bir kısmı toprak altında kalmış, bir kısmı yol ve bina yapımları esnasında kırılmış ya da üzerleri tamamen kapatılmışıır.
}

\section{1}

Güvenlik Stratejileri

Cilt: 16

Say1: 34 
edebilmek için önden arkaya doğru daralan bir pencereye sahip ${ }^{56}$ ve

Güvenlik Stratejileri

Cilt: 16

Sayı: 34 arkadan giriş kapısı olan, havalandırma sistemi bulunmayan en küçük korugandır. ${ }^{57}$ Bunların demir ve betondan yapılan ön duvar cephe kalınlığ 1 yaklaşık 70 santimetre yan, arka ve çatı kalınlıkları ise 30 santimetre civarındadır.

2. Tip olanların çatı ve duvarları birinci tip koruganlara göre daha kalın olup bunların tek penceresi ve kapısı vardır. Bulundukları konuma göre içesinde sadece top ya da ağır makinalı tüfek bulunur. Konumu ve stratejik önemine göre bu koruganlarda havalandirma sistemi vardır. $\mathrm{Bu}$ tip koruganların havalandırma sistemi koruganın küçüklüğüne binaen sadece kol gücüyle çalıştırılabiliyordu. ${ }^{58}$

3. Tip koruganların içerisine top ve makinalı tüfekler konulur. Bunların duvar kalınlıkları yaklaşık bir metre çatı kalınlıkları ise yaklaşık bir buçuk metredir. Genellikle üçüncü ve dördüncü tip büyük koruganların kapıları üzerinde inşa tarihleri ile kaçıncı korugan olduğuna dair numara vardır. Bazılarının kapı üzerindeki numaraları silinmiş ya da tahrip olmuştur. Bu üçüncü ve dördüncü tip koruganların tamamına havalandırma sistemi kurulmuş, ancak bu koruganlar askerî açıdan önemini yitirince ilgili mekanizmalar kaderine terk edilmiştir. Koruganların içerisinde bulunan havalandırma sistemi aksamı sökülerek hurda olarak satılmıştır. Çatalca-Büyükçekmece Çakmak Hattı'nda Kasım 2019 tarihi itibariyle sadece bir tane havalandırma sistemi kalan üçüncü tip korugan vardır. ${ }^{59} \mathrm{Bu}$ havalandırma sistemleri Fransa'da yapılan Majino Hattı havalandırma sistemleriyle birebir aynıdır. ${ }^{60}$ Üçüncü tip koruganları Çatalca, Büyükçekmece Gölü veya dere

${ }^{56}$ Pencerenin böyle olmasının nedeni içeriden makinalı tüfekle ateş edecek askerlere geniş açı kazandırmak, dışarıdan açılan ateşe karşılık hedefi küçültmek içindir.

${ }^{57}$ Bkz. Ek 11. Fotoğraf ektedir.

${ }^{58}$ Bkz. Ek 12. Fotoğraf ektedir.

${ }^{59} \mathrm{Bu}$ koruganın içerisinde havalandırma sisteminin kalmasının nedeni Büyükçekmece İlçesi şehir merkezine yakın olması ve özel mülkiyet içerisinde bulunmasından dolayıdır. Bkz. Ek 13.

${ }^{60}$ Bkz. Ek 14. Fransa'daki havalandırma sistemi fotoğraf ektedir. 
İkinci Dünya Savaşı'nda Kıyı ve İç Hat Savunması:

Çakmak Hattı (Büyükçekmece-Çatalca) Koruganları

kenarlarında ya da vadiye hâkim tepelerde görmek mümkündür. ${ }^{61}$

4. Tip koruganlar üçüncü tiplere göre daha da büyüktür. Bunlar, topların ve makinalı tüfeklerin bulunduğu iki ya da üç bölümü olan stratejik noktalarda, genellikle kendi bölgesindeki hâkim tepeye yapılmışlardır. Bahsi geçen diğer üç tip, göl, dere ve kenarındaki koruganların bölgelerini müdafaada yetersiz kaldığı veya sükût ettiği durumda dördüncü tip korugan devreye girecektir. ${ }^{62}$ Bahsi geçen 4.tip büyük koruganlardan birisi, Büyükçekmece ilçesi Eskice Çiftliği mahallesinde 2 pafta, 126 parsel sayıl1, 321.00 metrekare yüz ölçümlü maliye hazinesi arazisi içerisindeki kültür varlığı olarak 2016 yılında tescillenmiştir. ${ }^{63} \mathrm{Bu}$ korugan yıllarca mahalleliler tarafından samanlık deposu olarak kullanılmış ve atıl durumdadır.

5. Tip olarak Çatalca-Büyükçekmece Çakmak hattında, Dağyenice Köyü'nün doğu kesiminde, cephe arkasında lojistik destek tüneli olan en büyük tip bir korugan tespit edilmiştir. Avrupalıların blockhouse adını verdiği, Osmanlı Devleti'nde tabya sistemine benzeyen toprak altında yapılan, tüneldeki raylı sistem vasıtasıyla üçüncü tip koruganlarla bağlantısı olan bu savunma sistemi Çakmak Hattı'nın en stratejik noktasında yapılmıştır. Raylı sisteme sahip tünelin kapladığı alan üzerinde ve yan taraflarında, yay şeklinde dizilmiş beş tane büyük üçüncü tip, iki tane de ikinci tip korugan bulunmaktadır. Zikredilen koruganların önünde ise, bir tane üçüncü tip, üç tane küçük korugan daha vardır. Çatalca ilçesi Dağyenice Köyü 426 parsel sayılı, 29.300 metrekare yüzölçümlü Maliyeye ait Hazine arazisindeki korugan Anastasios Surları ile Balkan Savaşı müstahkem mevkiindeki hat ile hemen hemen aynı yerdedir. ${ }^{64}$ Bir tane girişi tespit edilen batı-doğu

\footnotetext{
${ }^{61}$ Bkz. Ek 15. Fotoğraf ektedir.

${ }_{63}^{62}$ Bkz. Ek 16. Fotoğraf ektedir.

63 https://korumakurulları.ktb.gov.tr/Eklenti/42199,1479-sayıl1-karartescil-fisi.pdf?0 Tescil belgeleri ektedir. Bkz. Ek. 17.

${ }^{64} 1912$ yılı Kasım ayında Bulgarlarla yapılan Balkan Savaşı Çatalca Muharebelerinde 17/18 Kasım akşamı Bulgar askerleri Dağyenice Köyünde bulunan Alaiya alayına baskın yapmış sonrasındaki çatışmalarda yaklaşık 660'ın üzerinde Türk askeri şehit
}

\section{3}

Güvenlik Stratejileri

Cilt: 16

Say1: 34 
404

Güvenlik Stratejileri

Cilt: 16

Sayı: 34

yönünde kolları bulunan bu korugan I. Grup kültür varlığı olarak tescil edilmiştir. ${ }^{65} \mathrm{Bu}$ tip birbirine tünellerle bağlı koruganlar Fransa Majino Hattı'nın yanı sıra İngiltere' de de vardır. ${ }^{66}$

6. Tip korugan sadece iki tane tespit edilmiştir. Bu koruganların en önemli özelliği diğer korugan tiplerine göre en tepe noktada bulunmalarıdır. Düşmanın diğer korugan tiplerini bertaraf ettikten sonra en son mücadele edeceği korugan bu altınc1 tip olanlardır. Bunların içerisinden sadece makinalı tüfek ile ateş edilebilir. Bunlar en hâkim mevkide top atışı ve uçak saldırılarına açık bulunduklarından dolayı çatı kalınlıkları diğer korugan tiplerine göre daha kalındır. Bunlardan bir tanesi Büyükçekmece Gölü'nün sona erdiği Karaağaç Köyü’ne en hâkim tepede Yiğittürk Caddesi ile Sirtköy Bulvarının birleştiği noktada bulunmaktadır. ${ }^{67}$ Bir diğer altıncı tip ise Terkos (Durusu) Gölü'nün sona erdiği, Yazlık Köyü ile Terkos Gölü'ne en hâkim tepededir. ${ }^{68}$ Son yıllarda Çatalca, Büyükçekmece ve Arnavutköy ilçelerindeki tapu daireleri tarafindan koruganların bulunduğu arazilere koruganları gösterir ayrı pafta numarası verilmeye başlanmıştır. BüyükçekmeceÇatalca Çakmak Hattında yaklaşık 300 tane üçüncü ve dördüncü tip, 800 'den daha fazla birinci ve ikinci tip olmak üzere, toplamda 1100'in üzerinde büyüklü küçüklü korugan olduğu değerlendirilmektedir.

Çakmak Hattı'nda koruganların en yoğun olarak yapıldığg yerlerden birisi de Çatalca İlç̧esine bağlı Bahşiyiş Köyüdür. Bu köy Büyükçekmece Gölü'nün bittiği noktada bulunmaktadır. Göl, 1989 yılında baraj yapılmadan önce köyün kuzeybatı tarafları tarla

olmuştur. En büyük koruganda, Alaiya alayının giriş kapısının olduğu tepede yaklaşık 30 yil sonra yapılmıştır.

65 https://korumakurulları.ktb.gov.tr/Eklenti/49962,istanbul---buyukcekmece---eskiceciftligi-mahallesi-2-p-.pdf?0 Tescil belgeleri ektedir. Bkz. Ek: 18.

${ }^{66}$ Paul Virillio, Bunker Archeology, çev. George Collins, Princetion Architectural Press New York, s. 103. İngiltere ile Fransa arasında bulunan Dover Boğazı'nı adını veren İngiltere'nin güneybatı ucunda bulunan Dover şehrinde de bu tür koruganları görmek mümkündür.

${ }^{67}$ Ek 19. Fotoğraf ektedir.

${ }^{68}$ Ek 20. Fotoğraf ektedir. 
İkinci Dünya Savaşı'nda Kıyı ve İç Hat Savunması:

Çakmak Hattı (Büyükçekmece-Çatalca) Koruganları

konumundadır. Düşmanın saldırabileceği en güçlü noktalardan birisi bu köy civarı olduğundan dolayı koruganların ön taraflarına demirden ve betondan ejderdişleri yapılmıştı. ${ }^{69}$ Korugan ve ejderdişlerinin yoğun olarak yapıldığı yerlerden birisi Terkos (Durusu) Gölü'nün Çatalca'ya doğru sona erdiği nokta olan Yazlık (Lazarköy) köydür. Burada betondan yapılan ejderdişlerinin uzunluğu yaklaşık bir buçuk metre civarındadır. Bu yüksekliğin yarısı toprak altındadır. Betondan yapılan ejderdişleri çapraz iki sıra halinde yapılmış ayrıca üstünde yaklaşık bir metre yüksekliğinde ray demirleri konularak güçlü bir set oluşturulmaya çalışılmıştır. ${ }^{70}$ Avrupa'da özellikle de Britanya'da denizlerden gelecek çıkarmalara karşı ejderdişleri yaygın olarak yapılmıştır. ${ }^{71}$

\section{Sonuc}

Türkiye'de araştırma konumuz olan İstanbul iline bağl1 daha çok Çatalca, Büyükçekmece ilçelerindeki Çakmak Hattı koruganları genellikle 1939-1942 yılları arasında yapılmıştır. Bu hat İkinci Dünya Savaş1 öncesinde koruganların en yoğun olarak yapıldığı bölgedir. Çünkü tarih boyunca bu hat Doğu Romalılar ve Osmanlılar tarafindan İstanbul'u savunmak için kullanılmıştır. Çatalca Büyükçekmece Çakmak Hattı haricinde Türkiye'ye bir saldırı olması durumunda Foça (İzmir), Gelibolu (Çanakkale), Trakya'nın muhtelif yerlerinde, İstanbul

\footnotetext{
${ }^{69}$ Göl, 1989 yılında baraj yapıldıktan sonra zikredilen ejderdişlerinden bir kısmı su altında kaldı. Çatalca ilçesi, Bahşiyiş mahalle muhtarı Arif Bel, 2018 yılında gölü arıtma çalışmaları esnasında bahsedilen ejderdişlerinin bir kısmının söküldüğünü ifade etmiştir. Tankların hızını kesebilmek için demirden ejderdişlerinin yanında birbirine bitişik T şeklinde kalın ejder dişleri yapılmış bunların gerisine ise tabya inşa edilmişti. Bu tabya duvarlarının bir kısmı gölün, baraj yapılmasıyla su altında kalmıştır. Bkz. Ek 21. Fotoğraf ektedir.

${ }^{70}$ Bkz. Ek 22. Fotoğraf ektedir. Hem Bahşiyiş Köyünde, hem de Yazlık Köyündeki ejderdişleri askerî açıdan önemini yitirdikten sonra ejderdişlerinin demir aksamı hurdacılar tarafından kesilerek satılmaya başlanmış, Bahşiyiş köylüleri ejderdişlerini kesen hurdacılara şikâyet etmiş, mahkemeye çıkarılan hurdacılar serbest bırakıldıktan sonra ejderdişlerinin demir aksamını daha fazla kesmeye başlamışlardır. Yazlık Köyündeki ejder demirden olan ejder dişleri de kesilmiştir.

${ }^{71}$ Peter Rowe, Hartlepool at War World War II Defences at High Throston and Cemetery Crossroads, Tees Archaeology 2012, s. 10. Bkz. Ek- 23.
}

\section{5}

Güvenlik Stratejileri

Cilt: 16

Say1: 34 
406

Güvenlik Stratejileri

Cilt: 16

Say1: 34
Boğazı'nın Karadeniz'e açılan kapısı konumundaki Anadolufeneri'nde ve Karasu (Sakarya) civarlarında da koruganlar yapılmıştır.

Çatalca ve Büyükçekmece'de yapılan saha çalışmalarında (Terkos Gölü-Büyükçekmece Gölü arasında) yaklaşık on farklı tipte korugan olduğu tespit edilmiş, en çok yapılan ve yaygın olan dört tip daha çok ele alınmış bunların görsellerine daha çok yer verilmiştir. Çalışmada 800'ün üzerinde birinci ve ikinci tip, 300 civarında da üçüncü ve dördüncü tip korugan olduğu, bu koruganların sayısının 1100'in üzerinde bulunduğu öngörülmüş, koruganlara son yıllarda bulundukları ilçelerce de ayrı pafta numaraları verilmeye başlanmıştır. Ayrıca düşmanın saldırma ihtimalinin en yüksek olduğu stratejik noktalardaki koruganların önüne demirden ve betondan ejderdişleri de yapılmıştır. Ejderdişlerinin en fazla olduğu yerler Büyükçekmece Gölü'nün bittiği Çatalca ilçesine bağlı Bahşiyiş köyü ile yine Terkos (Durusu) Gölü’nün sona erdiği Çatalca'ya bağlı Yazlık Köyüdür.

Çatalca-Büyükçekmece Çakmak Hattı'nda, Fransızların Majino Hattı'nda yaptığ 1 stratejik hatalara düşülmemiş, Fransızların yaptığ 1 gibi sadece hâkim tepelere değil vadilere ve göl kenarlarına da koruganlar yapılmıştır. Çakmak Hattı koruganları bu özelliği ile bir nevi Almanların inşa ettiği Siegfried Hattı'na benzemektedir. Birinci tip koruganlar daha çok üçüncü ve dördüncü tip koruganları korumak ve savunmaya yardımcı olmak için yapılmışlardır. Çatalca Büyükçekmece Çakmak Hattı koruganları Majino Hattı koruganlarına göre daha küçüktür.

İkinci Dünya Savaşı öncesi ve esnasında Türkiye'ye bir saldırı ihtimali durumunda savunma sığınakları olarak inşa edilen koruganlara, Türkiye savaşa girmediği için ihtiyaç kalmamıştır. Koruganların yapılması ve Türk Ordusu tarafından savaş tatbikatlarının uygulanması Türk Silahlı Kuvvetlerinin bir savaşa karşı ne kadar hazırlıklı olduğunu göstermesi açısından önemlidir.

Hülasa: İkinci Dünya Savaşı'ndan sonra askerî açıdan önemini yitiren koruganlar, bir nevi kaderine terk edilmişlerdir. Günümüzde bu tarihî mirasın yaşatılabilmesi için koruganların bir kısmının askerî tarih turizmine açılması ilk akla gelen çaredir. Bir dönem askerî birlikler tarafından kullanılan bu koruganların, halkın kolayca ulaşabileceği 
İkinci Dünya Savaşı'nda Kıyı ve İç Hat Savunması:

Çakmak Hattı (Büyükçekmece-Çatalca) Koruganları

yerleşim yerlerine yakın olanlardan, küçükten büyüğe doğru birer numunesi tadilat edilir ve içleri aslına uygun olarak donatılabilirse Büyükçekmece-Çatalca Çakmak Hattı'nın turizm açısından önemi daha da artacaktır.

Ayrıca, Çatalca, Çakmak Hattı'nın bulunduğu aynı bölgede, İstanbul'u savunmak maksadiyla, Osmanlı Devleti tarafindan, 1877-1878 Osmanlı-Rus Savaşı öncesi askerî tabyalar yapılmıştır. Bu tabyaların, 1912-1913 Balkan Savaşı öncesinde tadilatı yapılmış, Balkan Savaşı'nda Bulgarların Çatalca'da durdurulmasında bu tabyalar önemli rol oynamıştır. Çatalca Çakmak Hattı'nın bulunduğu bölgede Gaziler Tepe, Asım Paşa Tabyası ve Alaiya Şehitlikleri bulunmaktadır. Hem şehitlikler hem de koruganların aynı yerde bulunması bölgenin stratejik önemini ortaya koymaktadır. Bu bölgenin açık hava müzesi haline getirilmesi durumunda, Osmanlı Devleti ile Türkiye Cumhuriyeti arasındaki tarih bütünlügünü anlatmak için, bu askerî açık hava müzesi, iyi bir örnek olacaktır.

\section{Summary}

The Çakmak Line Blockhouses in the Towns of Çatalca and Büyükçekmece, affiliated to the City of Istanbul, Turkey, which are the subjects of our research, were generally constructed between 1939 and 1942. The said line was actually the region where in the blockhouses were most densely built prior to World War II, for this line was used by both the Eastern Romans and the Ottomans to defend Istanbul throughout the history. Other than the Çakmak Line of Çatalca - Büyükçekmece, blockhouses were also built in the vicinities of Foça (Izmir), Gelibolu (Çanakkale), various places of Thrace, Anadolufeneri, which is located in a place that serves as a gate of Bosporus opening into the Black Sea, and Karasu (Sakarya) in case of any attack against Turkey.

Through the field researches carried out in Çatalca and Büyükçekmece (between Lake Terkos and Lake Büyükçekmece) about ten different types of blockhouses were discovered, whereof the four mostly-constructed and common types were more closely dealt with and more visuals thereof were given. Again, in the mentioned study it was 
presumed that there existed over 800 blockhouses of primary and secondary types and around 300 blockhouses of tertiary and quaternary

Güvenlik Stratejileri

Cilt: 16

Sayı: 34 types, thus totaling over 1100. On the other hand, these blockhouses began to be given separate sheet numbers by the towns wherein they are located during the recent years. Again, ferroconcrete dragon's teeth were built in front of those blockhouses that were erected on the strategic spots that were most likely to be assaulted by enemies. The places with the most dragon's teeth are the Village of Bahşiyiş, affiliated to the Town of Çatalca, where Lake Büyükçekmece ends, as well as the Village of Yazlık, again affiliated to the Town of Çatalca, where Lake Terkos (Durusu) ends.

The strategic faults incurred by the French on Majino Line were avoided in the Çatalca - Büyükçekmece Çakmak Line, i.e. - unlike the French - blockhouses were built not only on commanding hills but also in valleys and lakesides, with which features the Çakmak Line blockhouses are sort of similar to Siegfried Line constructed by the Germans. The primary type of blockhouses was rather designed to help with the protection and defense of the tertiary and quaternary types of blockhouses. The blockhouses on Çatalca - Büyükçekmece Çakmak Line are smaller than those on Majino Line.

The blockhouses, which had been constructed as defense shelters in case of any attack against Turkey before and during World War II, were no more needed as Turkey did not take part in the said war. The construction of blockhouses and exercises for war by the Turkish army are important from the aspect of showing how Turkish Armed Forces have ever been ready for war.

To summarize: The blockhouses that lost their significance from the military aspect after World War II have sort of been left to their fate. That some of the blockhouses are opened to the tourism of military history is the remedy that first occurs to mind for the maintenance of this historical heritage today. Of these blockhouses, which were once used by military units, that are close to those residential areas accessible to the public, if an exemplary one of each type - from the smaller to the bigger ones - is restored and equipped internally in conformity to the original form thereof, the importance of Büyükçekmece - Çatalca Çakmak Line from the point of tourism will further increase. 
İkinci Dünya Savaşı'nda Kıyı ve İç Hat Savunması:

Çakmak Hattı (Büyükçekmece-Çatalca) Koruganları

Furthermore, military bastions were built by the Ottoman State prior to 1877-1878 Ottoman-Russian War in the same region as Çatalca, Çakmak line in order to defend Istanbul. These bastions, which had been restored before 1912 - 1913 Balkan War, played an important role in blocking the Bulgarians in Çatalca during the Balkan War. In the region where Çatalca Çakmak Line lies are situated Gaziler Tepe (Hill), Asım Paşa Bastion and Alaiya Cemetery of Martyrs. In truth, that both the cemetery of martyrs and blockhouses are located in the same place evidences the strategic significance of the region. If this region is made into an outdoor military museum, it will be a good example to tell about the historical integrity between the Ottoman State and Turkish Republic.

\section{KAYNAKÇA}

ARNA, Cihat; "Koruganlar ve Daime Tahkimatıyla Takviye Edilmiş Bir Mevzie Karş1 Taarruzda Koruganların Zaptı", Askerî Mecmua, Sayı: 130, Eylül 1943, s. 314-319.

ASLAN, Deniz; “Özellikle Büyükçekmece Koruganları,” Betonart Dergisi, İstanbul, Sonbahar 2004, s. 55-67.

DOĞAN, Zekeriya; İkinci Dünya Savaşı ve Türkiye'nin Savaş Stratejisi, Cinius Yay., İstanbul 2016.

DONNELL, Clayton; The Battle For The Maginot Line, Pen \& Sword Military Yay., South Yorkshire 2017.

GUDERİAN, General Heinz; Bir Askerin Anıları, Çev. Korgeneral (E) İhsan Gürkan, Kastaş Yayınevi, İstanbul 2018.

KALFAOĞLU, F.; "Fransa Harbi," Askerî Mecmua, Sayı: 120, Mart 1941, s. 69-81.

KEEGAN, John; İkinci Dünya Savaş1, Çev. Samet Öksüz, Say Yay., İstanbul 2016.

LIDDİARD, Robert and SIMS, David; "A Guide To Second World War Archaeology In Suffolk Guide 4: Stop Lines", Barnwell Print Ltd., England 2014.

LUDWING, G. Von; "Maginot Hattının İnşasına Dair Mütalaalar", Çeviren: Arif Bilen, Askerî Mecmua, Sayı: 120, Mart 1941, s. 82-91.

NEİBERG, Michael S.; Dünya Tarihinde Savaş, Çev. Mehmet Tanju Akad, Tarih Vakfi Yurt Yay. İstanbul 2011.

OCAK, Mustafa Tahir - TEKİN, Ömer Faruk; “Anadolufeneri Koruganları”, Betonart Dergisi, Say1: 60/2019.

ÖZDEMIR, Hikmet; Savaşta ve Barışta Kemal Atatürk, Doğan Kitap, İstanbul 2019. ÖZAL, İlkin Başar; Kısa İkinci DünyaSavaşıTarihi, Timaş Yayınları, İstanbul 2019. Protecting Twentieth - Century Military Structures in Wales 49 TH Annual Report 2002 - 03, Ancient Monuments Board for Wales, Cardiff 2003, s. 1-24. 
Salim AYDIN

410

Güvenlik Stratejileri

Cilt: 16

Sayı: 34

ROWE, Peter; Hartlepool at War World War II Defences at High Throston and Cemetery Crossroads, Tees Archaeology 2012.

Singapore In World War II A Heritace Trail, National Heritage Board In January 2013. SOMMERVILle, Donald; Resimli Harp Tarihi II. Dünya Savaşı, Çev: Ali Önsan, Türkiye İş Bankası Kültür Yay., 2012.

STRICKLAND, Alan; The Stroudwater Pillboxes: A Review of the WWII Pillboxes Along the Stroudwater Canal, Project S04, Issue 1, March 2007.

The War Againist Japan U.S. Army in World War II. Pictorial Record, Editör: Kent Roberts Greenfield, U.S. Government Printing Office, Washington D.C., 2001.

TURGAY, Hamdi; "Majino, 'Majino Hattı'nın Cephesi Üzerinde ve Derinlikleri", Askerî Mecmua, Say1: 113, Haziran 1939, s. 553-564.

Türk Harp Tarihi Derslerinde Adı Geçen Komutanlar, Harp Akademileri Komutanlığ Yay. Harp Akademileri Basımevi, İstanbul 1983.

VİRILLIOO, Paul; Bunker Archeology, çev. George Collins, Princetion Architectural Press New York, s. 103.

WELSH, June - COOPER, Carly - SCOTT, Randal; Survey of World War II. Pillbox, Murlough, Country Down, Survey Report No: 34, Ulster Archaeological Society c/o School of Natural and Built Environment The Queen's University of Belfast, Belfast 2017.

WEST, James Alexander; An Object Biography of WW2 Pillboxes in Cumbria and Lancashire and the Defensive Structures of Point edu Hoc, Normandy, France, Central Lancashire Üniversitesi Yüksek Lisans Tezi, March 2013.

YALÇINER, Muammer; "Sigfrit (Siegfried) Hattı", Askerî Mecmua, Sayı: 137, Haziran 1945.

https://korumakurulları.ktb.gov.tr/Eklenti/42199,1479-say1l1-karartescil-fisi.pdf?0 https://korumakurulları.ktb.gov.tr/Eklenti/49962, istanbul---buyukcekmece---eskiceciftligi-mahallesi-2-p-.pdf?0 
İkinci Dünya Savaşı'nda Kıyı ve İç Hat Savunması:

Çakmak Hattı (Büyükçekmece-Çatalca) Koruganları

\section{EKLER}

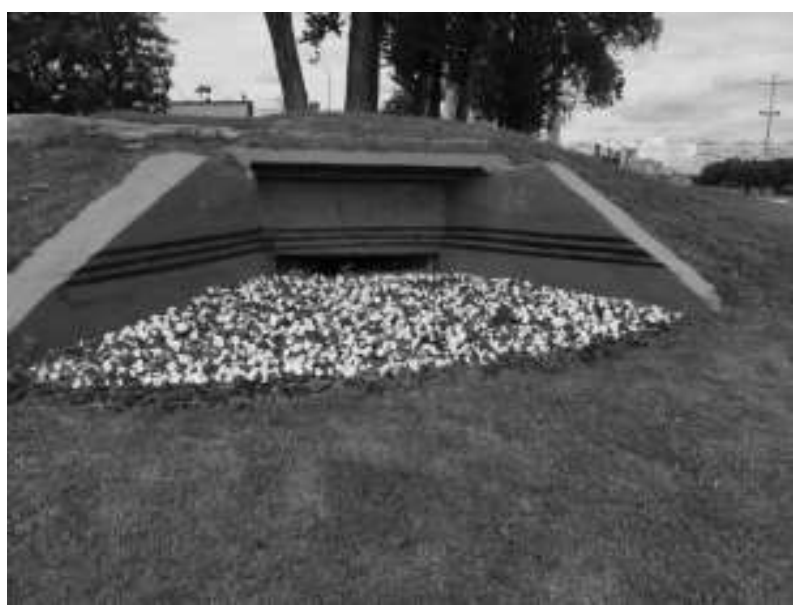

\section{1}

Güvenlik

Stratejileri

Cilt: 16

Say1: 34

Ek 1. a. Rusya St. Petersburg. Koruganın önden çekilmiş fotoğrafi. Temmuz 2015'de Salim Aydın tarafından çekilmiştir.

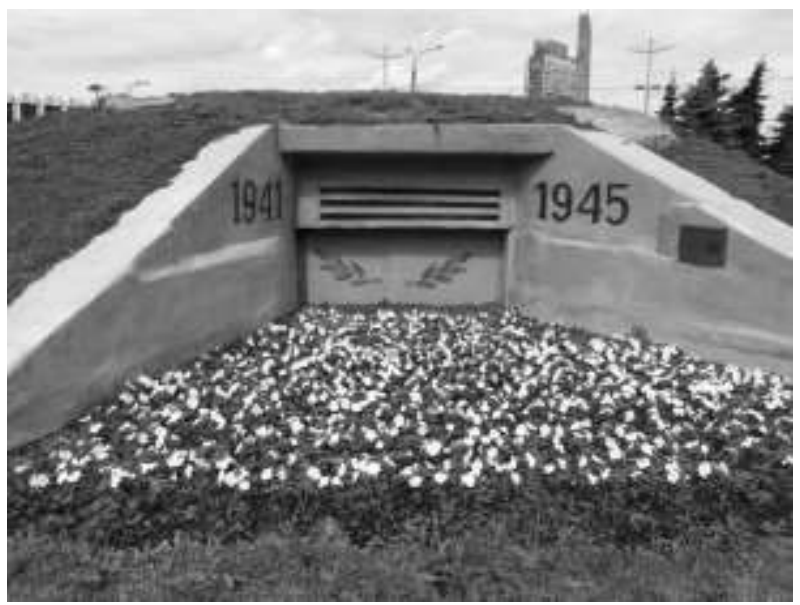

Ek 1. b. Rusya St. Petersburg şehir merkezine yaklaşık 15 kilometre uzaklıktaki koruganın arkadan çekilmiş fotoğrafi. 


\section{Salim AYDIN}

412

Güvenlik

Stratejileri

Cilt: 16

Sayı: 34

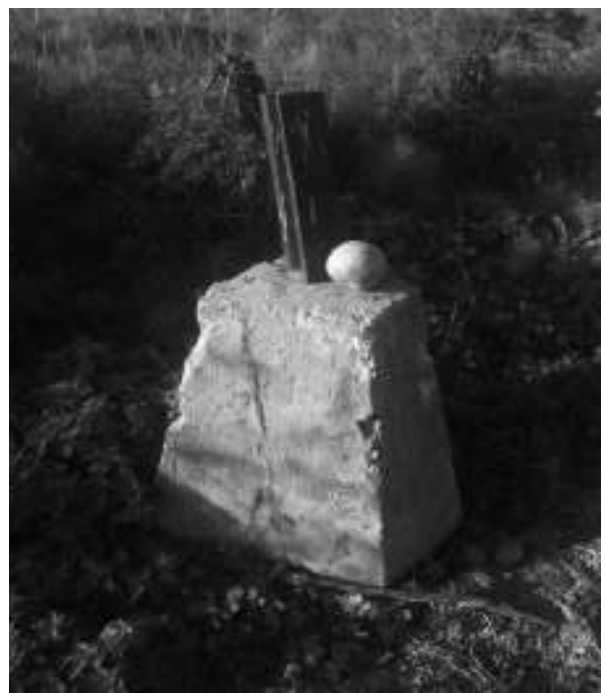

Ek 2. İstanbul Çatalca Yazlık Köyü. Ejderdişleri (anti-tank cubes) genellikle betondan ve ray demirlerinden yapılmıştır. Çatalca-Büyükçekmece, Çakmak Hattında betondan yapılmış ejderdişlerinin üzerine genellikle ray demirleri de eklenmiştir.

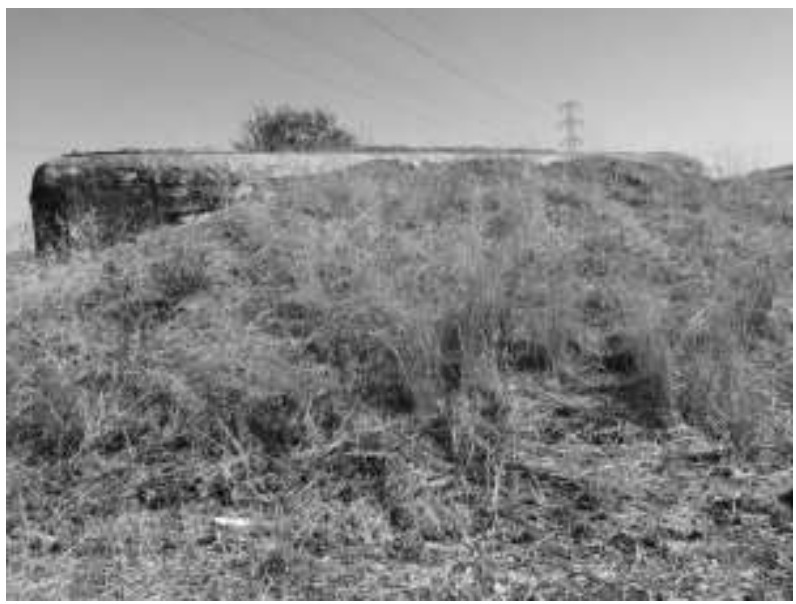

Ek 3. a. Büyükçekmece-Çakmaklı Köyü yolu, Eskice Çiftliği yol ayrımı 100 metre ileride solda, koruganın arkadan fotoğrafı. 
İkinci Dünya Savaşı'nda Kıyı ve İç Hat Savunması:

Çakmak Hattı (Büyükçekmece-Çatalca) Koruganları

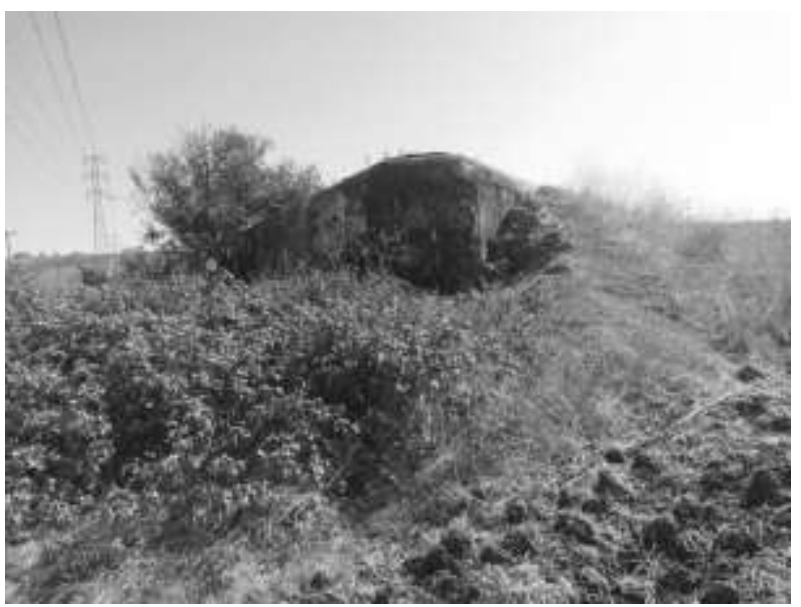

Güvenlik

Stratejileri

Cilt: 16

Say1: 34

Ek 3.b. Büyükçekmece-Çakmaklı Köyü yolu, Eskice Çiftliği yol ayrımı

100 metre ileride solda. Büyük koruganlarda, düşmanın gelebileceği cephesinin dış kısmı koruganın çatısına kadar taşlarla doldurulmuş, bu taşların üzerine toprak

dökülerek koruganlar arazi yapısına uydurularak gizlenmeye çalışılmıştır.

Bundaki gaye, mevzilere taarruz edecek düşmanın keşiflerini önlemekti. Koruganın düşmanın geleceği cephesinin ilk önce taşla doldurulmasının nedeni; korugana yapılan top atışının tahrip etkisini azaltmaktır. Koruganın yandan görünüşü.

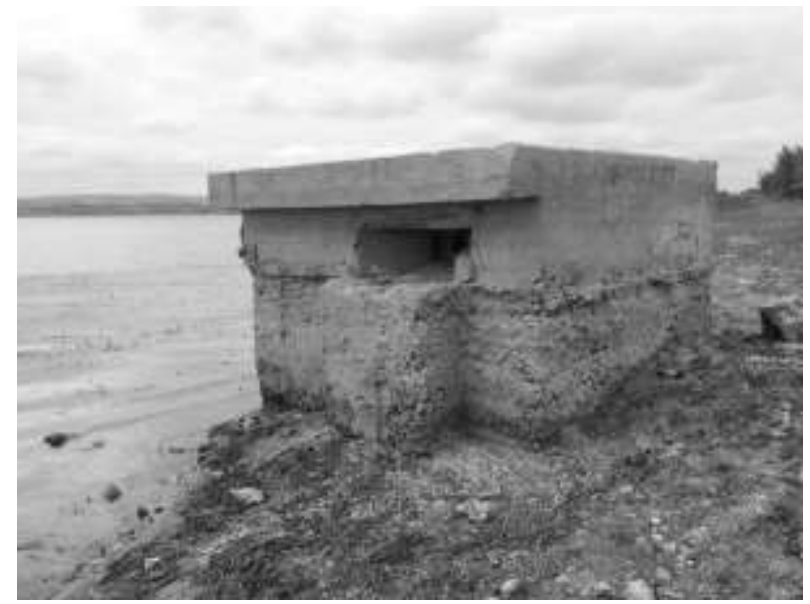

Ek 4. a. Büyükçekmece-Eskice Çiftliği Köyü yolu solda göl kenarında. 


\section{Salim AYDIN}

414

Güvenlik

Stratejileri

Cilt: 16

Sayı: 34

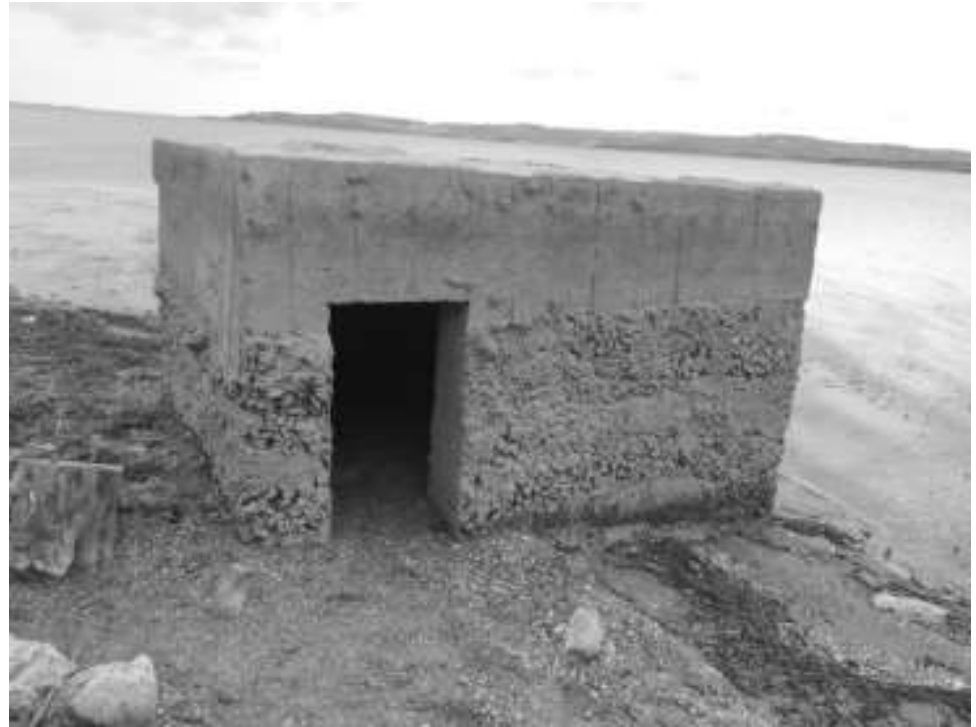

Ek 4. b. Büyükçekmece-Eskice Çiftliği Köyü yolu solda göl kenarında. Düşmanın büyük koruganlardan birini susturmak amacıyla yaptığı saldırı karşısında o koruganı koruyan diğer komşu koruganlar devreye girmeli ve bu yardım daha küçük makinalı silahlar vasıtasıyla yapılmalıdır. Böylece taarruz edilen koruganın kendini müdafaa edemediği alanlar korunmuş olur. Yukarıda Büyükçekmece Gölü kenarında, Büyük koruganları koruyan en küçük (1.Tip) korugan tipinin ön ve arka cephelerden çekilmiş fotoğrafi görülmektedir.

Fotoğraflarda koruganın dış cephesinden de anlaşıldı ̆̆ üzere bu tip koruganların büyük bölümü toprak altında idi. Bunları, düşmanın fark etmemesi için sadece atış penceresi ve çatısı görünmekteydi. Bu fotoğraflar istisnadır.

Çünkü Büyükçekmece Gölü 1989 yılında baraj yapıldıktan sonra su seviyesinin yükselmesiyle dalgalar koruganın etrafındaki toprakları aşındırmıştır. 
İkinci Dünya Savaşı'nda Kıyı ve İç Hat Savunması:

Çakmak Hattı (Büyükçekmece-Çatalca) Koruganları

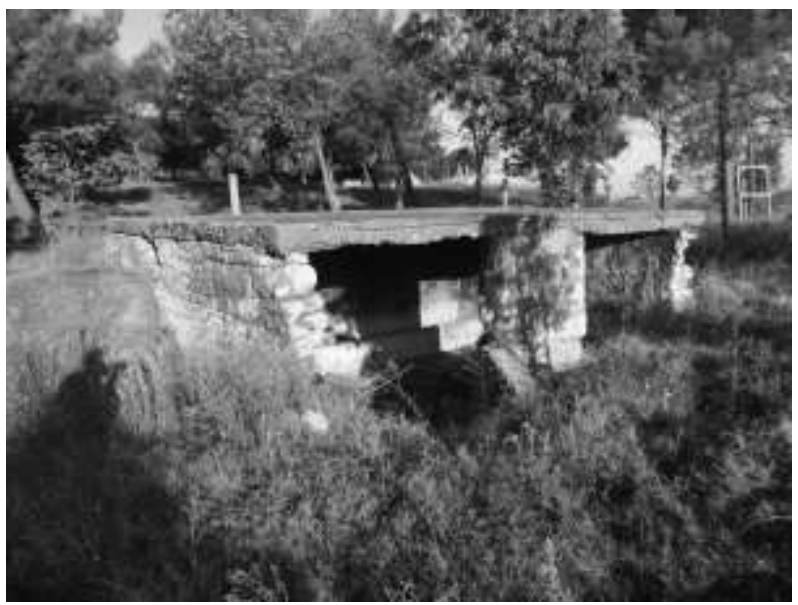

\section{5}

Güvenlik

Stratejileri

Cilt: 16

Say1: 34

Ek 5. Bu küçük korugan karayolu yapılırken Beylikdüzü'nden Büyükçekmece'ye inen E5 karayolunun arasında kalmıştır. Yapıldığı dönemde hem göle tepeden gören hem de Marmara Denizi'ne hâkim bir tepede bulunan bu korunanın içerisine daha sonra hayvanlar için su yalağı yapılmıştır. Korugan şimdi yapılaşma

ve yol yapım çalışmaları esnasındaki düzenlemeden dolayı ne Marmara Denizi'ni ne de Büyükçekmece Gölü’nü görmektedir.

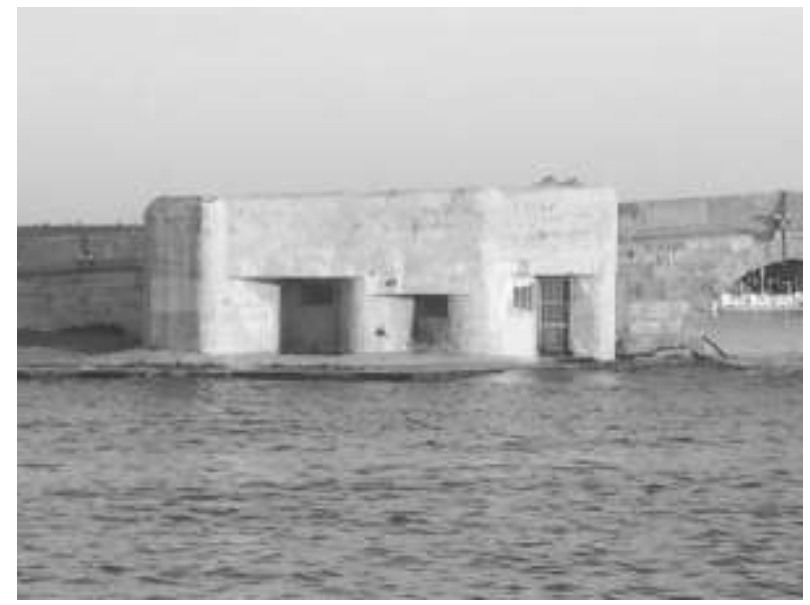

Ek 6. a. Büyükçekmece Gölü üzerindeki Mimar Sinan Köprüsü önündeki üçüncü tip korugan. 


\section{Salim AYDIN}

\section{6}

Güvenlik Stratejileri

Cilt: 16

Sayı: 34

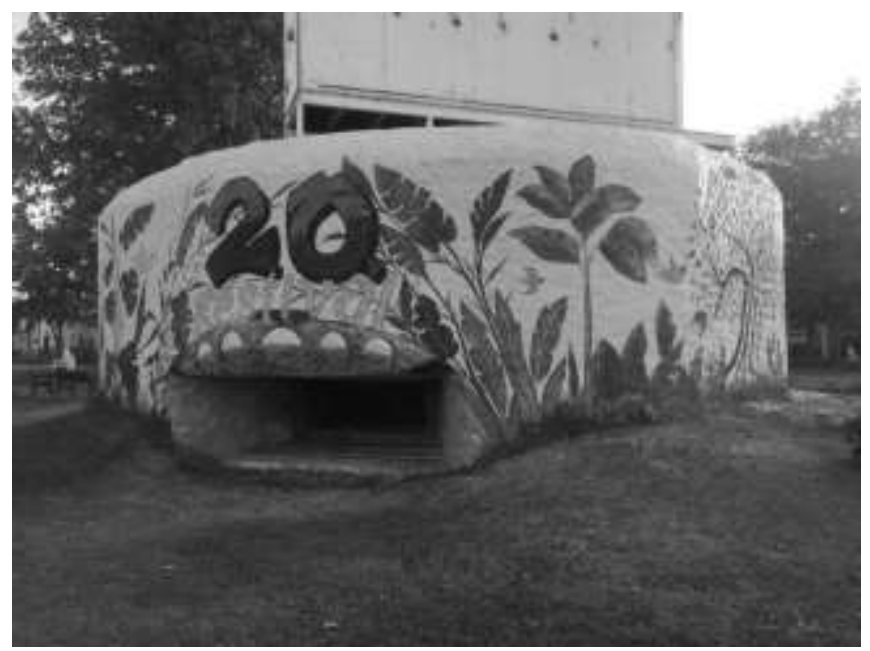

Ek 6. b. Büyükçekmece Kültür Park meydanında ön cepheden korugan.

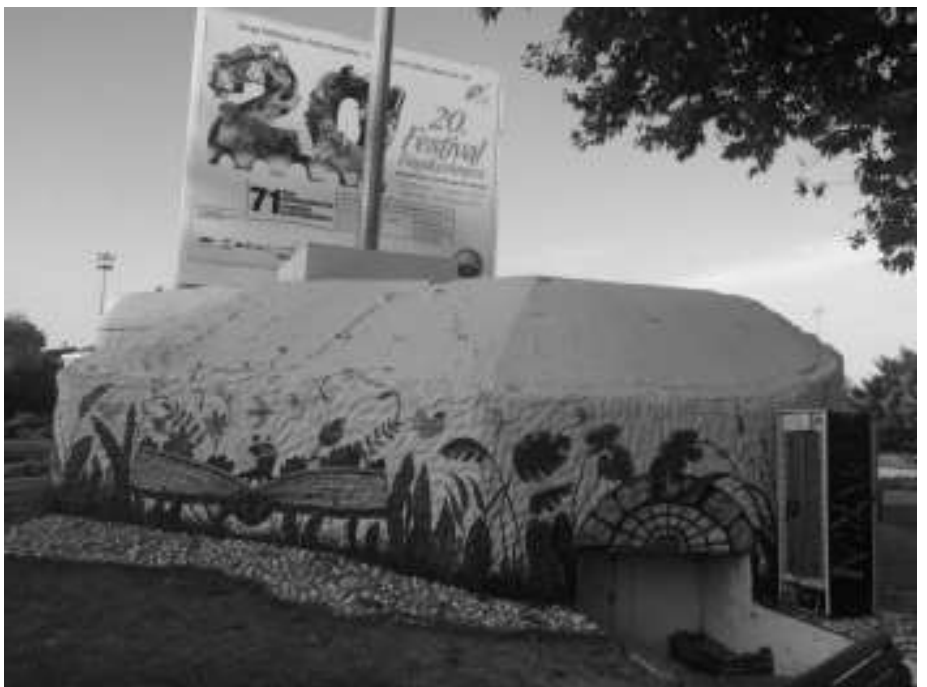

Ek 6. c. Büyükçekmece Kültür Park meydanında arka cepheden korugan. Büyükçekmece Gölü doğu kıyısında bulunan iki korugan ile ilgili olarak İstanbul Teknik Üniversitesi Mimarlık Fakültesi Dekanlığınca bir çalışma yapılmıștır. Yapılan çalıșmada Büyükçekmece Gölü kenarında ve şehir merkezine 
İkinci Dünya Savaşı'nda Kıyı ve İç Hat Savunması:

Çakmak Hattı (Büyükçekmece-Çatalca) Koruganları

yakın iki simetrik korugan tespit edilmiş, bu koruganların fotoğrafları ve rölöveleri yayınlanmıştır. Her iki korugan da su baskınlarına karşı özel drenaj ve atık su tahliye sistemlerine sahiptir. Ancak bunların tahliye sistemlerinin çalışmadığı ve gölün 1989 yılında baraj haline getirilmesiyle gölde su seviyesinin yükseldiği koruganlardan bir tanesinin alt katının tamamen su ile dolduğu tespit edilmiştir. Daha sonra, su seviyesinin düşmesiyle koruganların içerisine girilerek çalışma sistemleriyle ilgili inceleme yapılmıştır. Bahsi geçen iki korugan hâlâ durmaktadır. Bir tanesi Büyükçekmece Gölü üzerinde, Kanuni Sultan Süleyman'ın talimatıyla 1566 yılında yapılmaya başlanan, Kanuni'nin vefatı ile 1567 yılında II. Selim döneminde inşası tamamlanan köprünün birinci bölmesinin bitti noktada yönü Marmara Denizi'ne bakan korugan bir diğeri, Büyükçekmece Kültür Parkının tam ortasında bulunmaktadır.

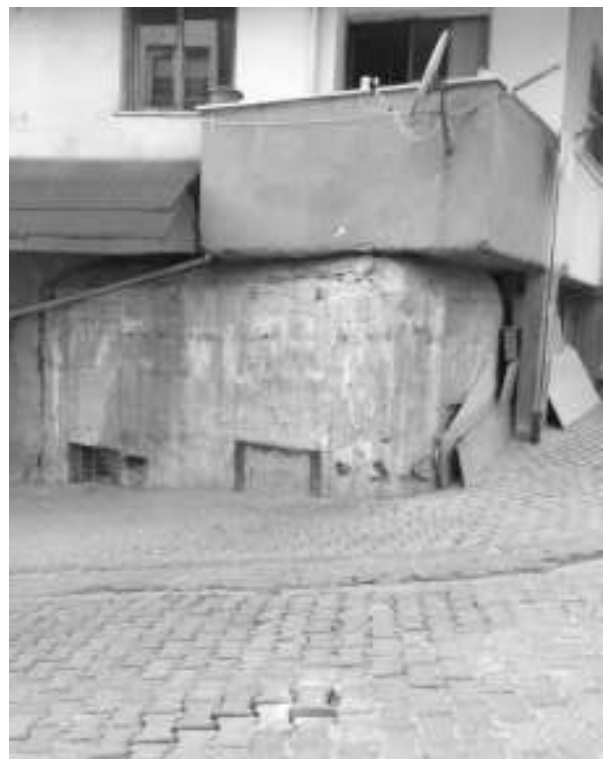

Ek 7. a. Büyükçekmece ilçesi 19 Mayıs Mahallesi Yıldız Sokak. 


\section{Salim AYDIN}

\section{8}

Güvenlik Stratejileri

Cilt: 16

Sayı: 34

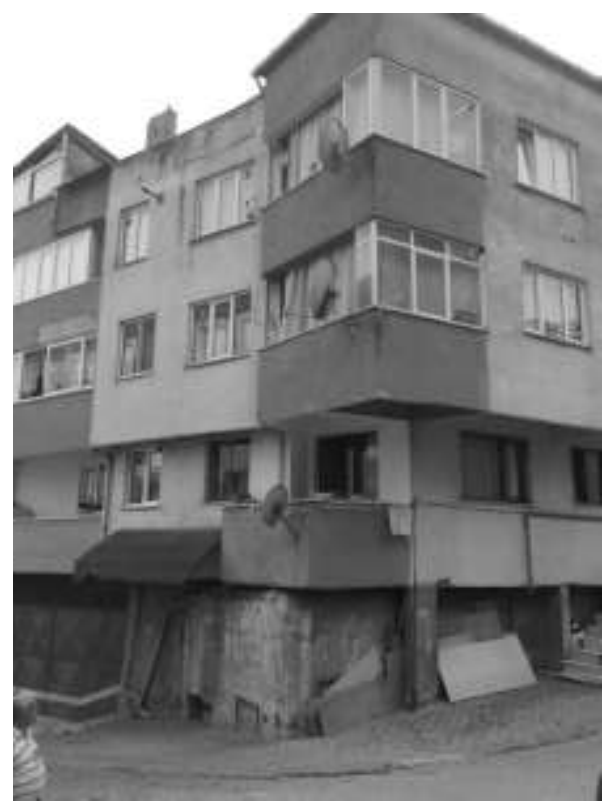

Ek 7. b. Büyükçekmece ilçesi 19 Mayıs Mahallesi Yıldız Sokakta korunanın üzerine dört katlı bina yapılmış, korugan bir nevi temel görevi görmüştür.

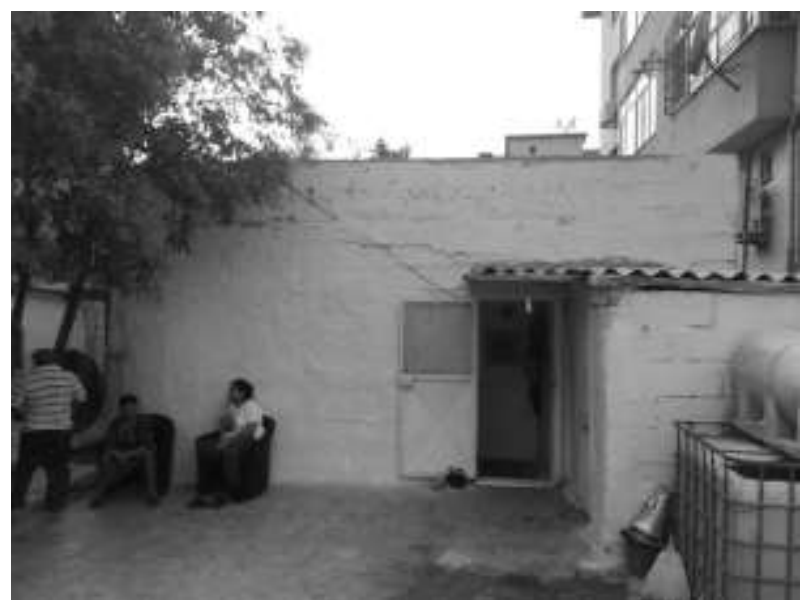

Ek 8. a. Büyükçekmece merkezde, Dizdariye Mahallesi Çınar Sokak. 
İkinci Dünya Savaşı'nda Kıyı ve İç Hat Savunması:

Çakmak Hattı (Büyükçekmece-Çatalca) Koruganları

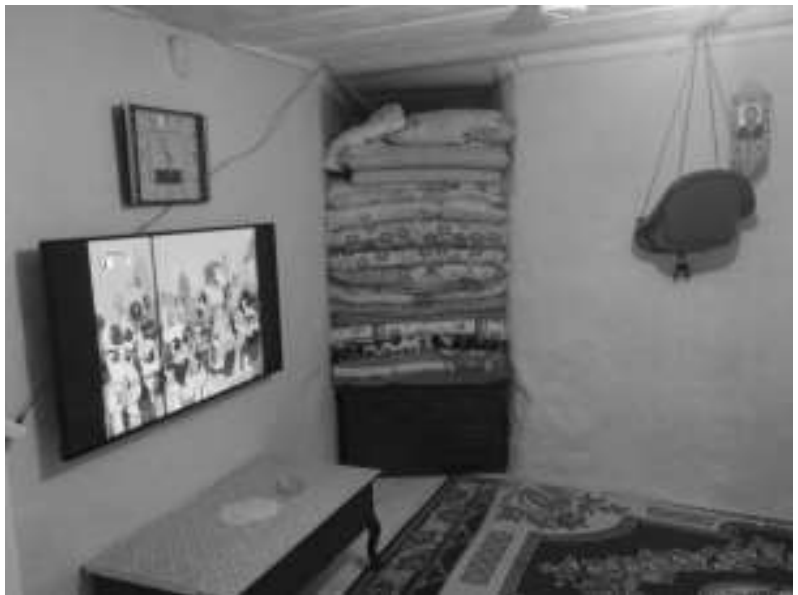

Güvenlik

Stratejileri

Cilt: 16

Say1: 34

Ek 8. b. Büyükçekmece merkezde, Dizdariye Mahallesi Çınar Sokak’ta, içerisine top ve makinalı tüfek yerleştirilen üçüncü tip koruganlardan birisi, günümüzde ev olarak kullanılmaktadır.

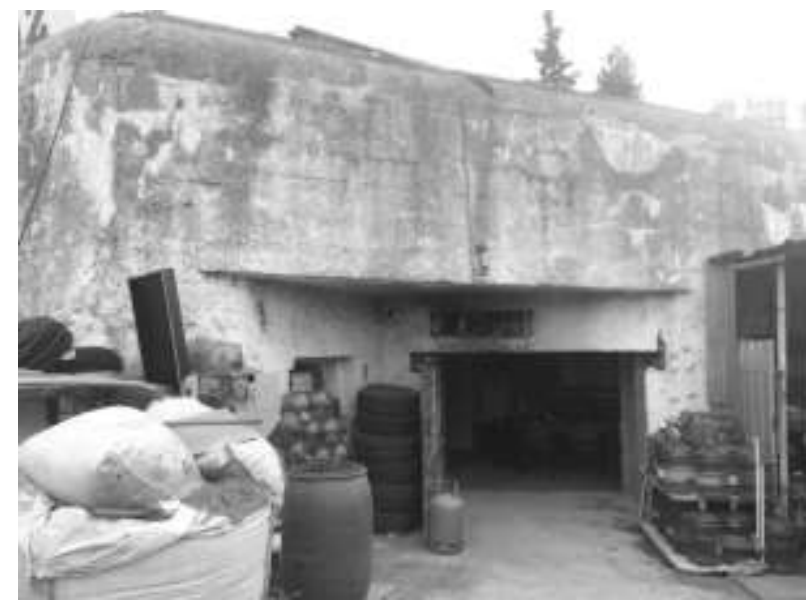

Ek 9. Mezarlık duvarını oluşturan koruganların en büyüğü Büyükçekmece Stadyolu Sokağı'nda ve depo olarak kullanılmaktadır. 
Güvenlik

Stratejileri

Cilt: 16

Sayı: 34

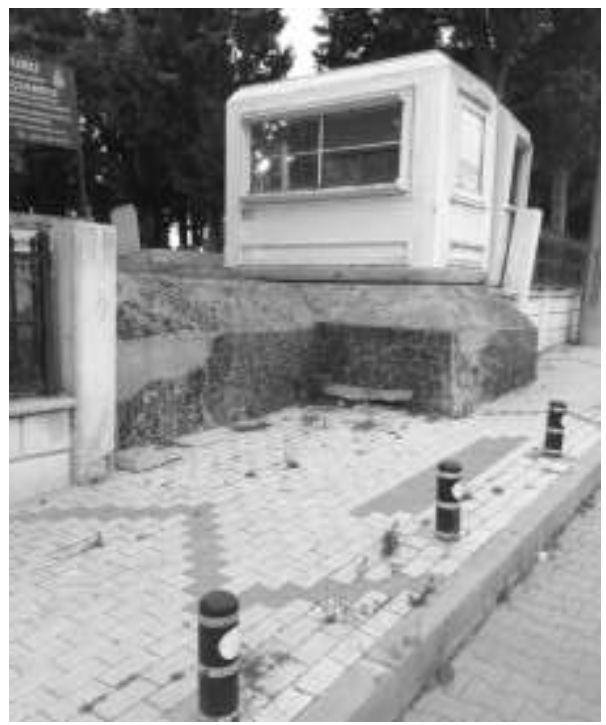

Ek 10. Mezarlık duvarını oluşturan koruganlardan birisi de Büyükçekmece Mezarlığı Gölboyu Caddesi üzerindedir. Bu koruganın üzerine beyaz bir bekçi kabini konuşmuş, koruganın sadece çatısı görünmekte diğer tarafları toprak altında kalmıştır.

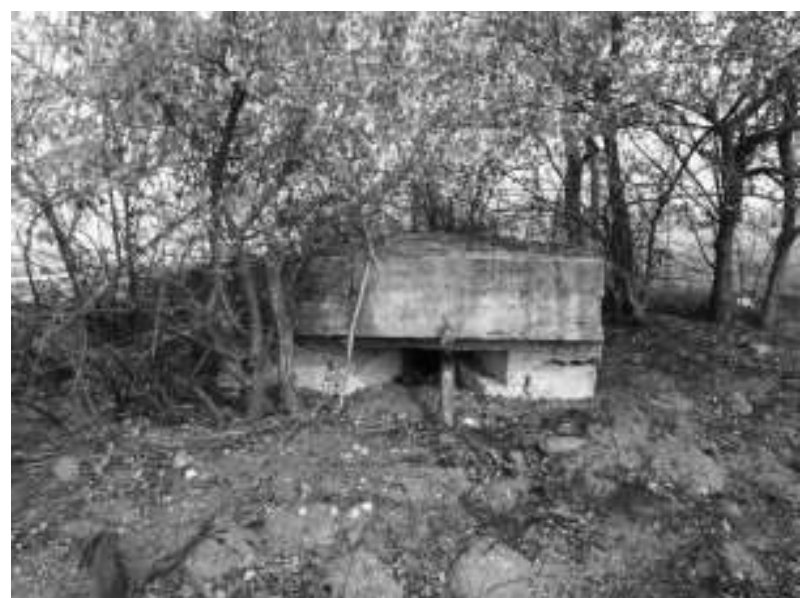

Ek 11. a. Birinci tip korugan örneği. Büyükçekmece-Eskice Çiftliği Köyü yolu sol tarafta. 
İkinci Dünya Savaşı'nda Kıyı ve İç Hat Savunması:

Çakmak Hattı (Büyükçekmece-Çatalca) Koruganları

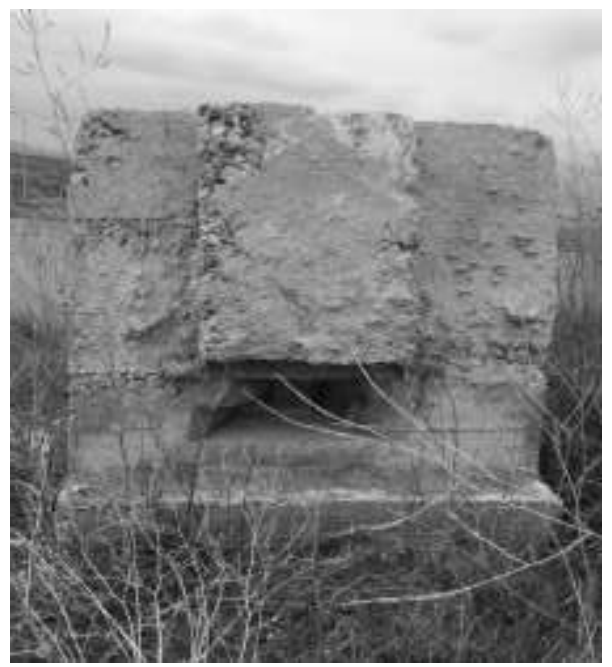

\section{1}

Güvenlik

Stratejileri

Cilt: 16

Say1: 34

Ek 11. b. Büyükçekmece Karaağaç Köyü, Birinci tip korugan yerinden sökülerek ters bir halde bir bahçe içerisinde durmaktadır. Bu tip en küçük koruganlar, genellikle büyük koruganların çevresinde bulunurlar. Küçük koruganın içerisine sadece makinalı tüfek vardır. Genellikle büyük bölümü toprak altındadır. Ateş edebilmek için önden arkaya doğru daralan bir pencereye sahiptir.

Arkadan giriş kapısı olup havalandırma sistemine sahip değildir.

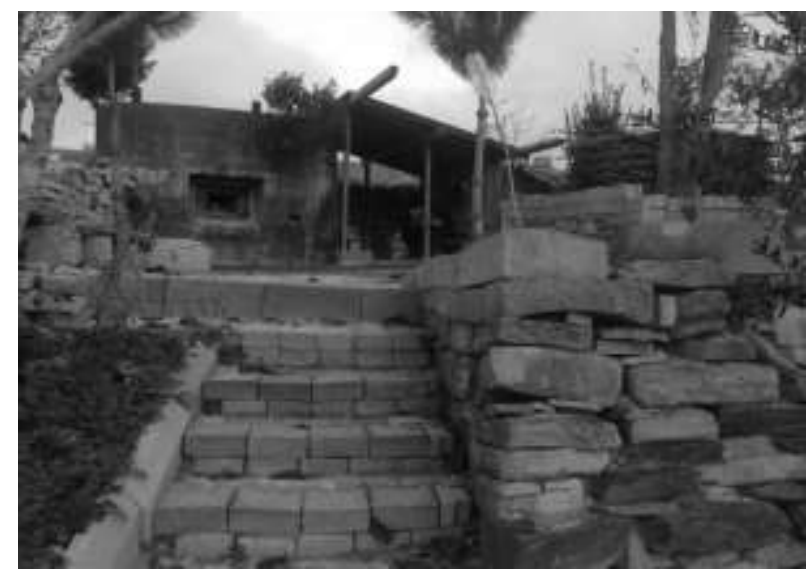

Ek 12. a. İkinci tip korugan Çatalca Yazlık. 


\section{Salim AYDIN}

422

Güvenlik Stratejileri

Cilt: 16

Sayı: 34

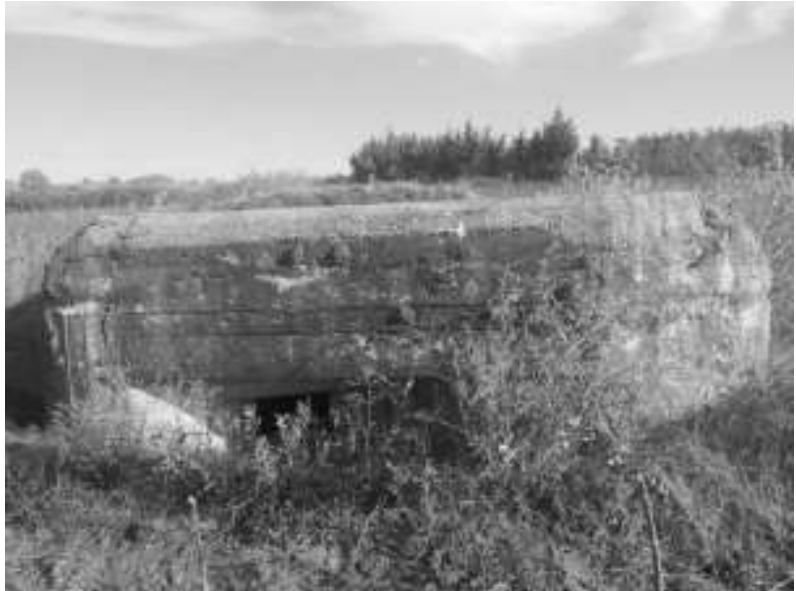

Ek 12. b. Büyükçekmece- Eskice Çiftliği yolu solda göle yaklaşık 300 metre uzaklıkta. İkinci tip koruganların çatı ve duvarları birinci tip koruganlara göre daha kalın olup bunların tek penceresi ve kapısı vardır. Bulundukları konuma göre içesinde sadece top ya da ağır makinalı tüfek bulunur. Konumu ve stratejik önemine göre bu koruganlarda havalandırma sistemi olabilir.

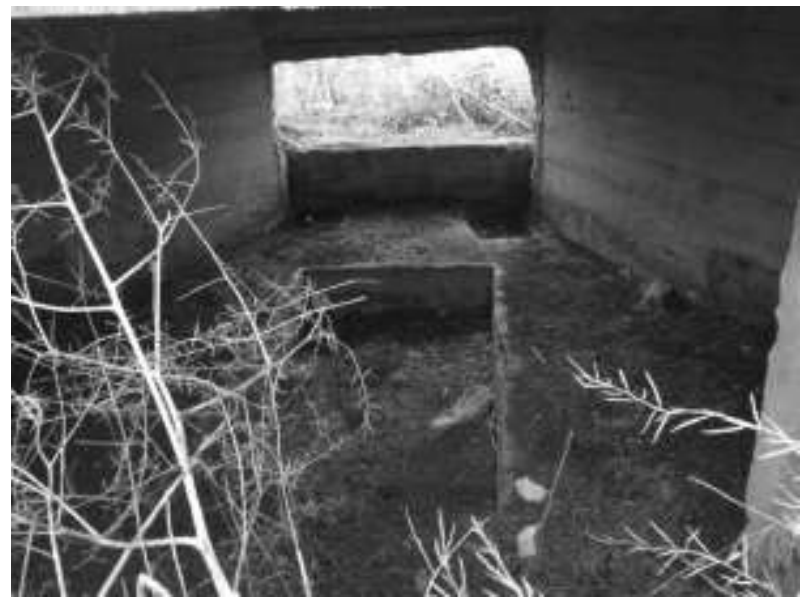

Ek 12. c. İkinci tip korugan içerisine topun nasıl yerleştirileceğini gösteren düzenek. 
İkinci Dünya Savaşı'nda Kıyı ve İç Hat Savunması:

Çakmak Hattı (Büyükçekmece-Çatalca) Koruganları

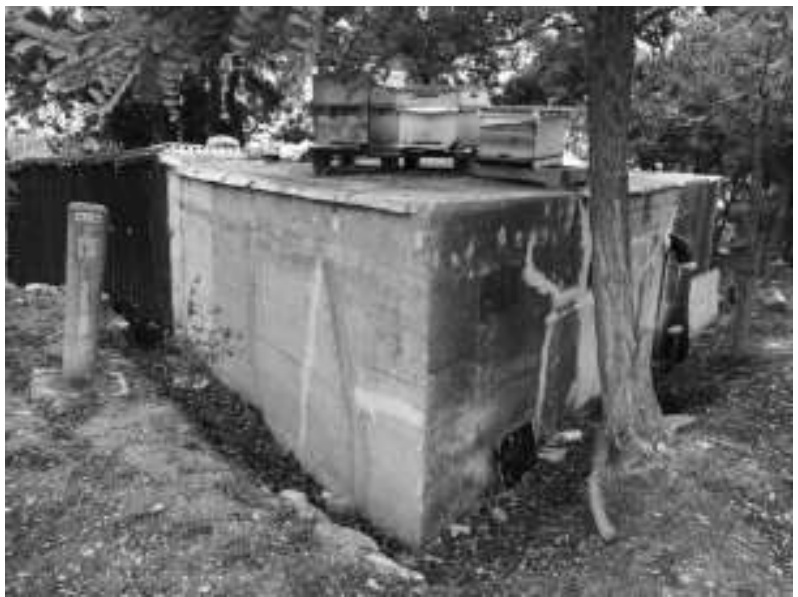

\section{3}

Güvenlik

Stratejileri

Cilt: 16

Say1: 34

Ek 12. d. Karaağaç-Bahşiyiş Köyü yolu, sol tarafta Büyükçekmece Gölü kenarında ev olarak kullanılan ikinci tip korugan.

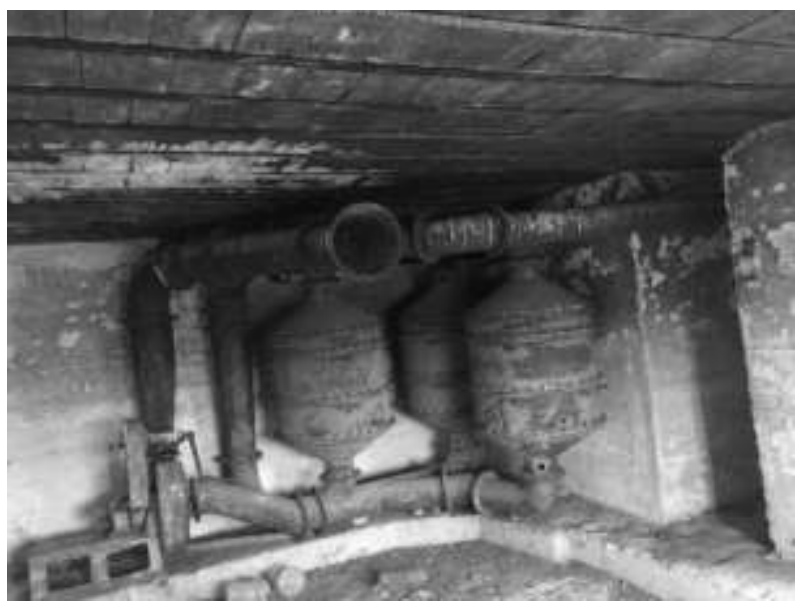

Ek 13. a. Büyükçekmece Stadyolu Sokağı sonunda özel mülkiyet içerisindeki arazide, üçüncü tip koruganların içeresinde bulunan havalandırma düzeneği. 
Salim AYDIN

424

Güvenlik

Stratejileri

Cilt: 16

Sayı: 34

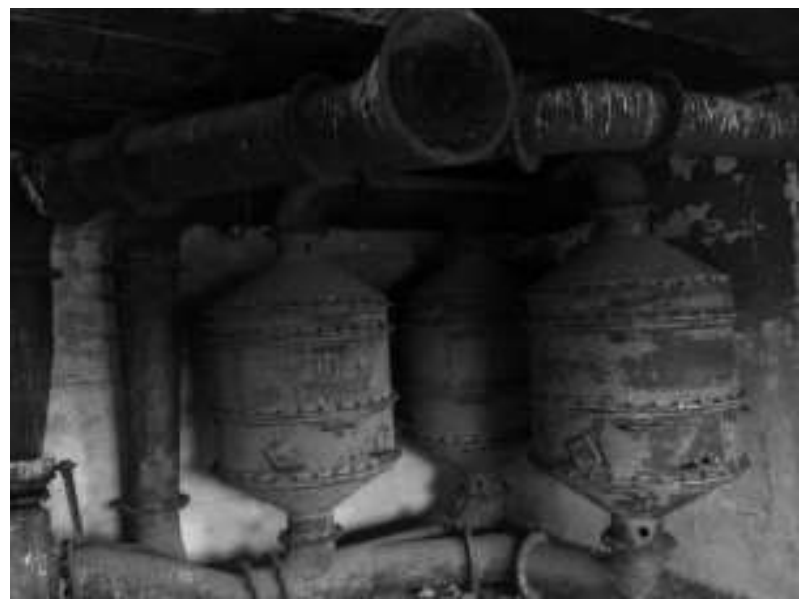

Ek 13. b. Üçüncü tip korugan havalandırma düzeneği.

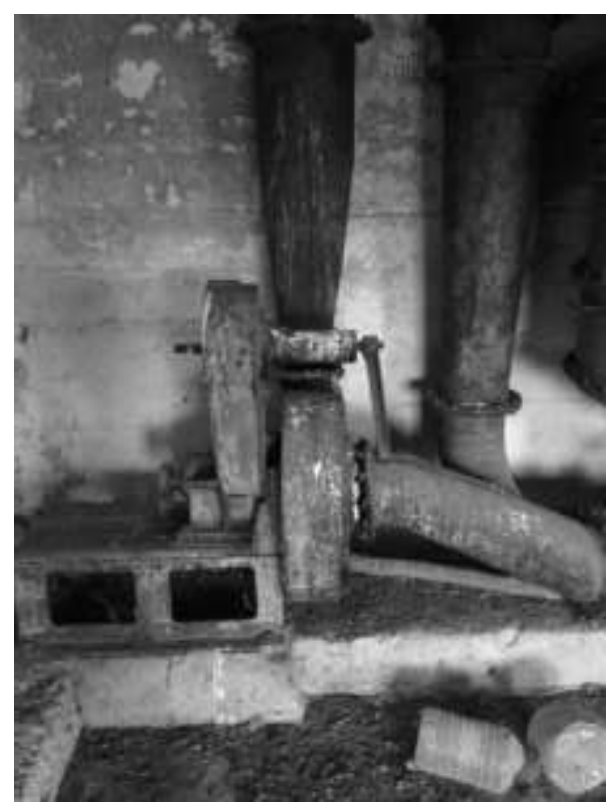

Ek 13. c. Havalandırma düzeneğini çalıştıran mekanizme. Gerektiğinde kol gücü ile de çalıştırılabilmektedir. 
İkinci Dünya Savaşı'nda Kıyı ve İç Hat Savunması:

Çakmak Hattı (Büyükçekmece-Çatalca) Koruganları

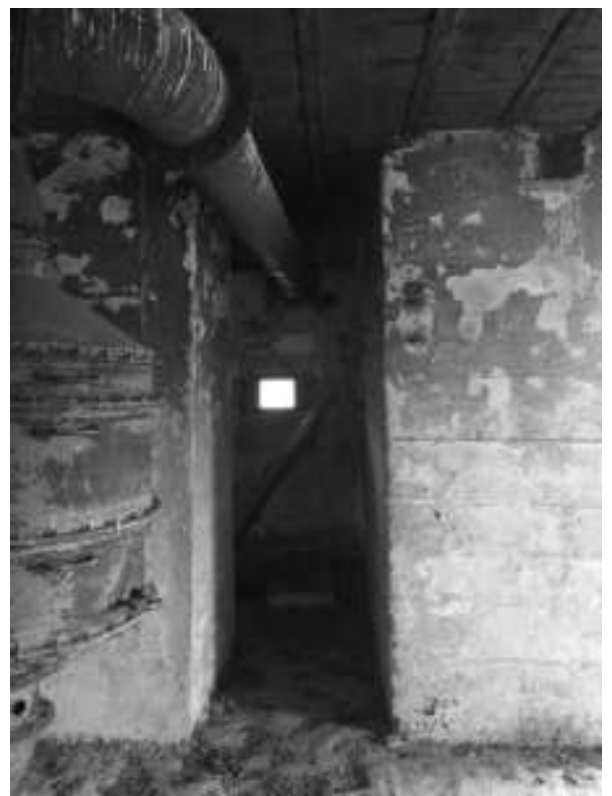

\section{5}

Güvenlik

Stratejileri

Cilt: 16

Say1: 34

Ek 13. d. Havalandırma düzeneğinin dışarı ile bağlantısını sağlayan kalın boru aksamı.

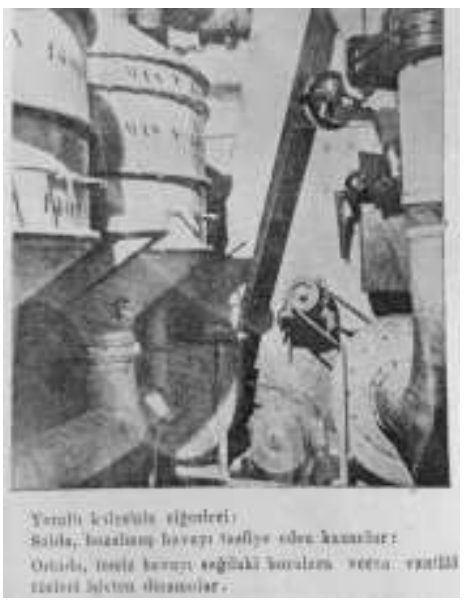

Ek 14. e. Majino Hattı'ndaki bir koruganda havalandırma sistemi. Kaynak; Hamdi Turgay, a.g.m., s. 562. Çakmak Hattı'ndaki havalandırma sistemi bunun aynısıdır. 


\section{Salim AYDIN}

\section{6}

Güvenlik Stratejileri

Cilt: 16

Sayı: 34

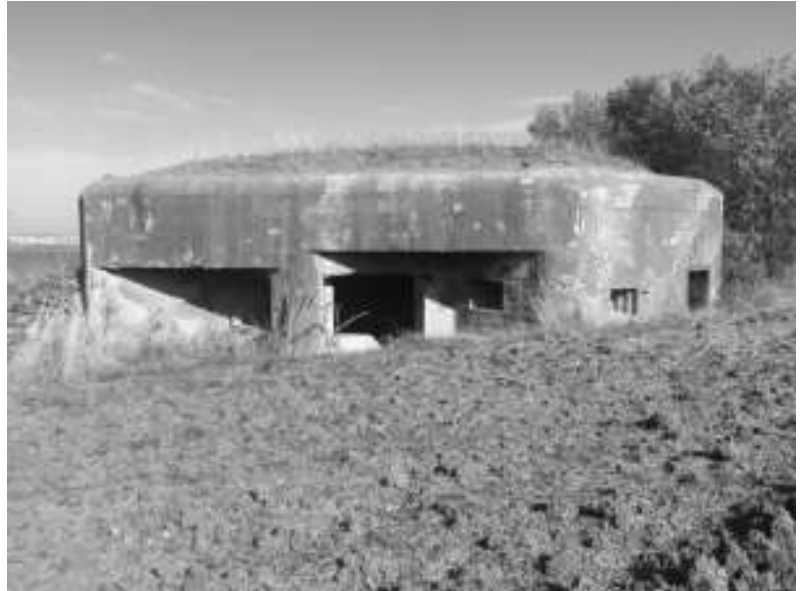

Ek 15. a. Büyükçekmece Spor Kompleksi üst tarafı tarla içerisinde üçüncü tip koruganın ön cepheden görünümü.

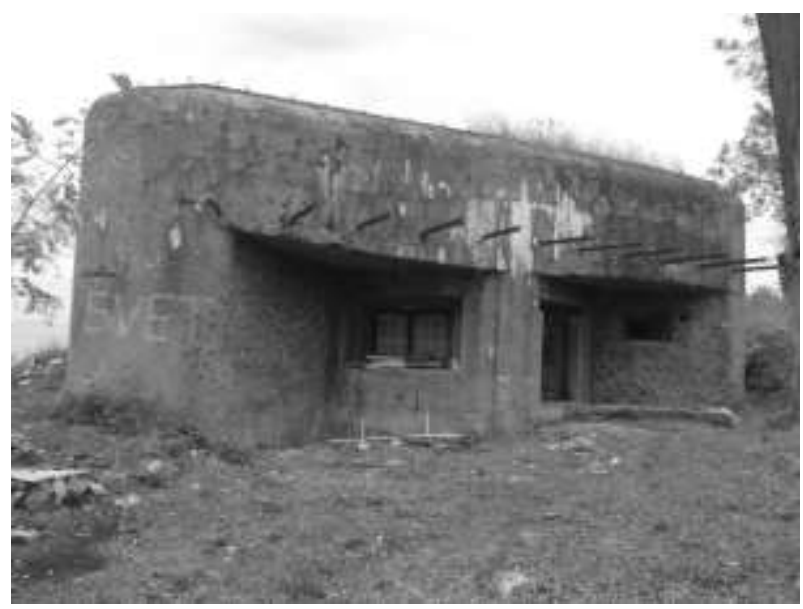

Ek 15. b. Büyükçekmece-Eskice Çiftliği Köyü yolu, solda, göl kenarında üçüncü tip koruganın yandan fotoğrafi. 
İkinci Dünya Savaşı'nda Kıyı ve İç Hat Savunması:

Çakmak Hattı (Büyükçekmece-Çatalca) Koruganları

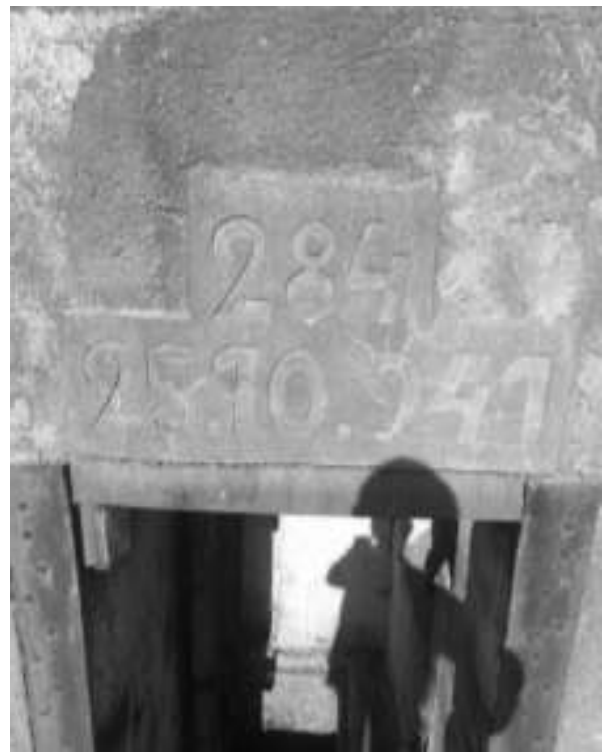

\section{7}

Güvenlik

Stratejileri

Cilt: 16

Say1: 34

Ek 15. c. Üçüncü tip koruganların üzerinde genellikle yapıldığ 1 tarih ve kaçıncı korugan olduğunu gösteren numara vardır.

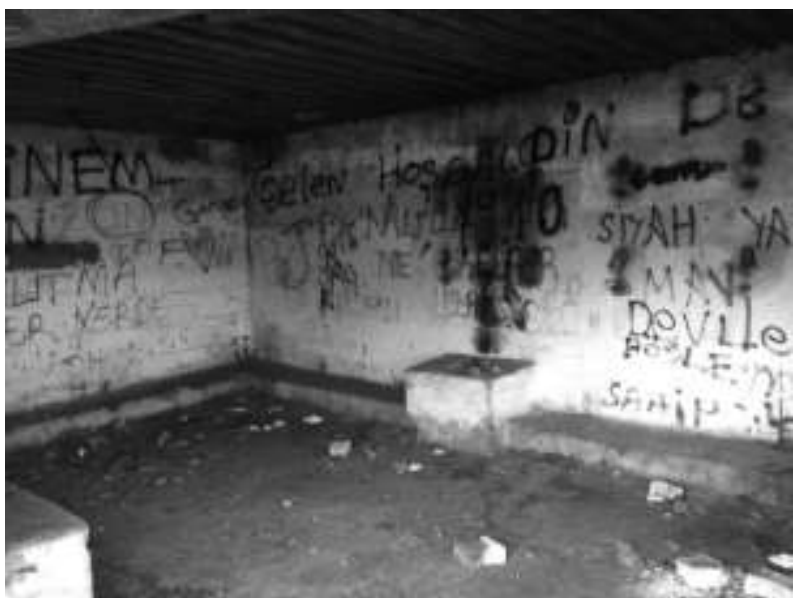

Ek 15. d. Büyükçekmece-Eskice Çiftliği yolu solda, göl kenarında üçüncü tip koruganın içi. Havalandırma sisteminin bütün demir aksamı sökülmüş. 


\section{Salim AYDIN}

\section{8}

Güvenlik

Stratejileri

Cilt: 16

Sayı: 34

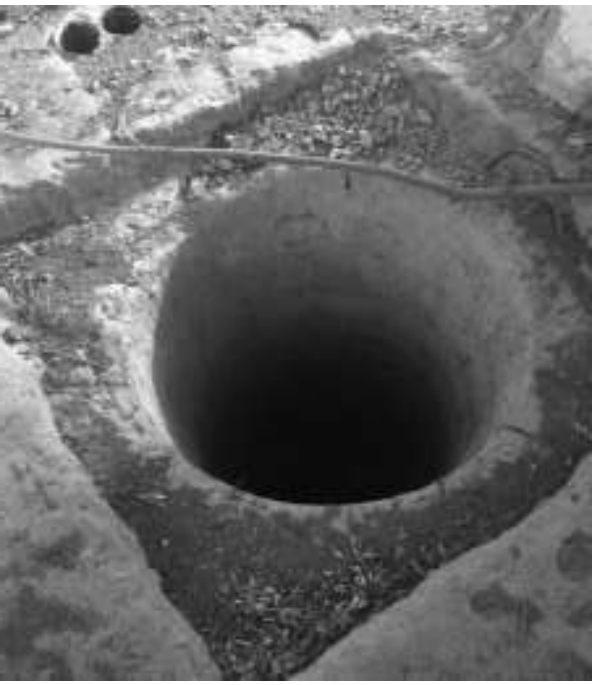

Ek 15. e. Korugan içerisinde su kuyusu, bazı kuyuların içerisinde hâlâ su bulunmaktadır. Kuyu kapağının açık hali.

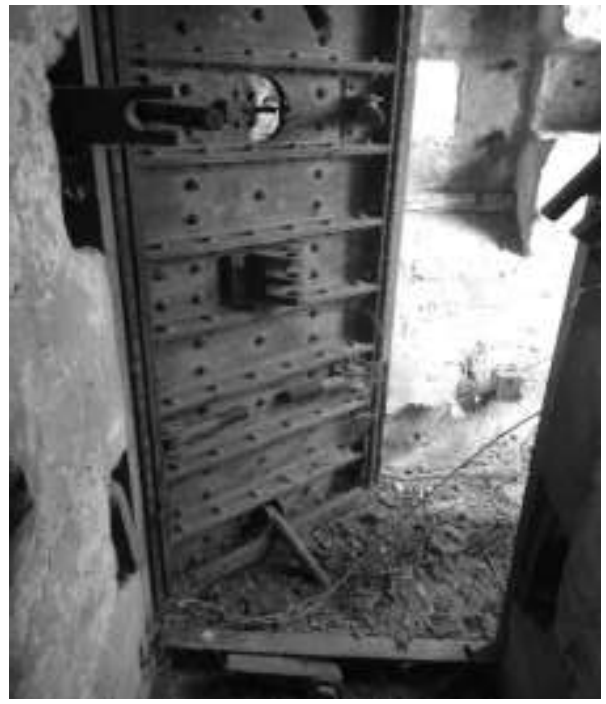

Ek 15. f. Demirden yapılmış, üçüncü tip koruganın iç kapısı. 
İkinci Dünya Savaşı'nda Kıyı ve İç Hat Savunması:

Çakmak Hattı (Büyükçekmece-Çatalca) Koruganları

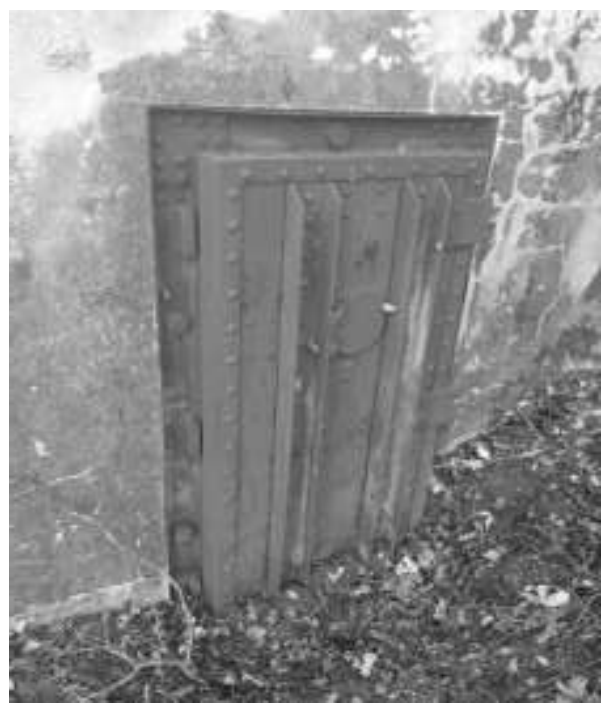

\section{9}

Güvenlik

Stratejileri

Cilt: 16

Say1: 34

Ek 15. g. Üçüncü tip koruganın dış kapısının kapalı olarak görünümü.

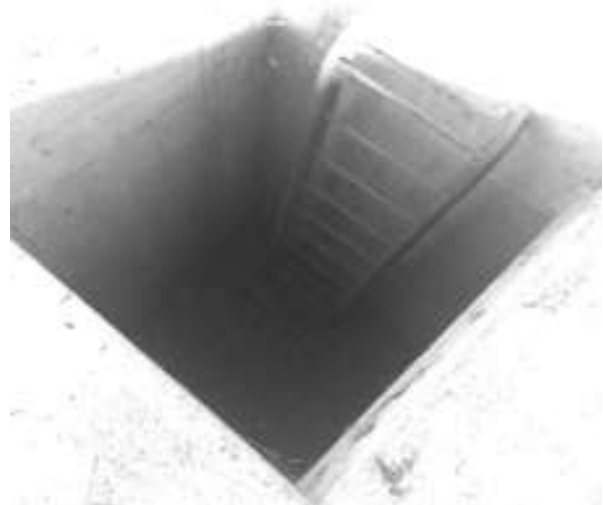

Ek 15. h. Üçüncü ve dördüncü tip koruganların altında genellikle sığınaklar bulunmakta bu sığınaklara merdivenle inilmekte ve çıkılmaktadır. 


\section{Salim AYDIN}

\section{0}

Güvenlik

Stratejileri

Cilt: 16

Sayı: 34

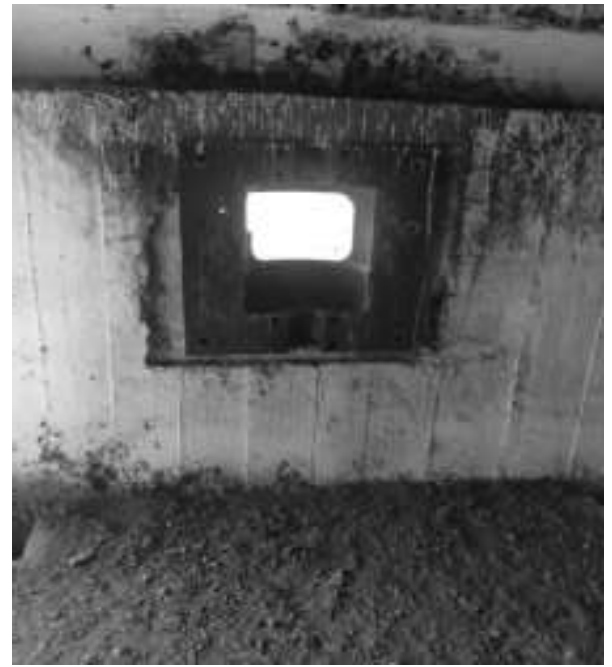

Ek 15. 1. Üçüncü tip koruganın içerisine yerleştirilen makineli tüfek yuvası.

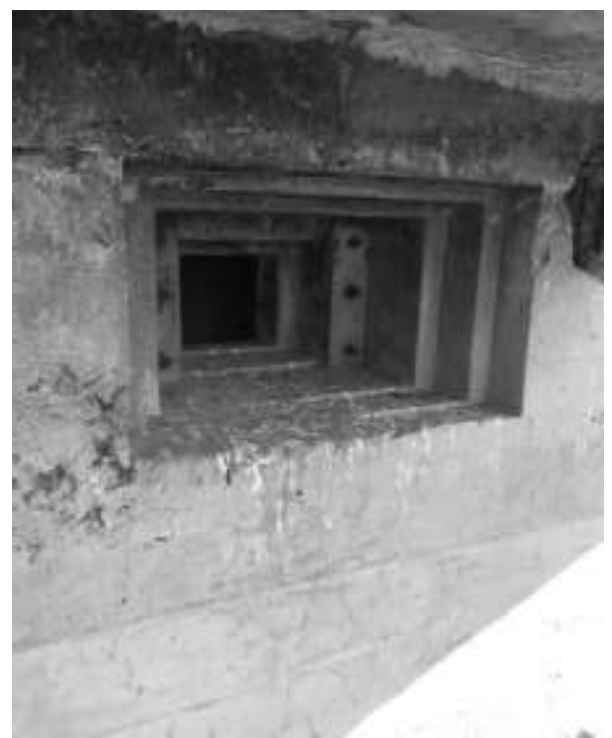

Ek 15. i. İçeriden makineli tüfek yerleştirilen üçüncü tip koruganın dış penceresinin görünümü. 
İkinci Dünya Savaşı'nda Kıyı ve İç Hat Savunması:

Çakmak Hattı (Büyükçekmece-Çatalca) Koruganları

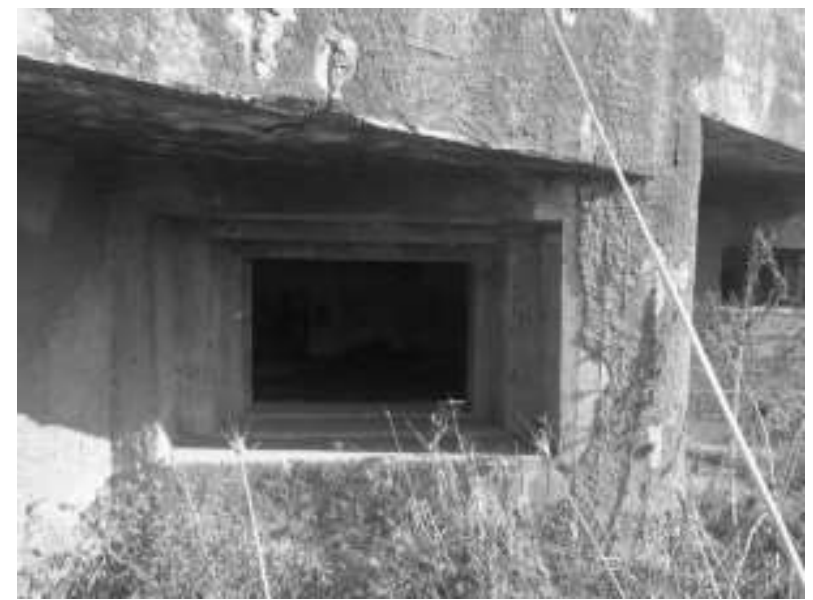

\section{1}

Güvenlik

Stratejileri

Cilt: 16

Say1: 34

Ek 15. j. İçerisine top yerleştirilen üçüncü tip koruganın dış pencere görünümü.

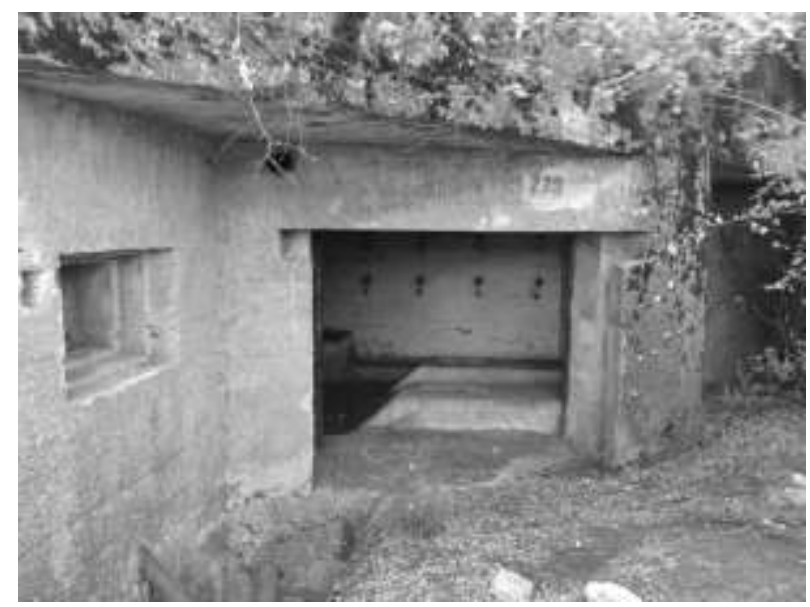

Ek 15. k. Üçüncü tip koruganlarda topların içeriye alındığı kap1 ve topların yerleştirildiği beton düzenek. 


\section{Salim AYDIN}

\section{2}

Güvenlik Stratejileri

Cilt: 16

Sayı: 34

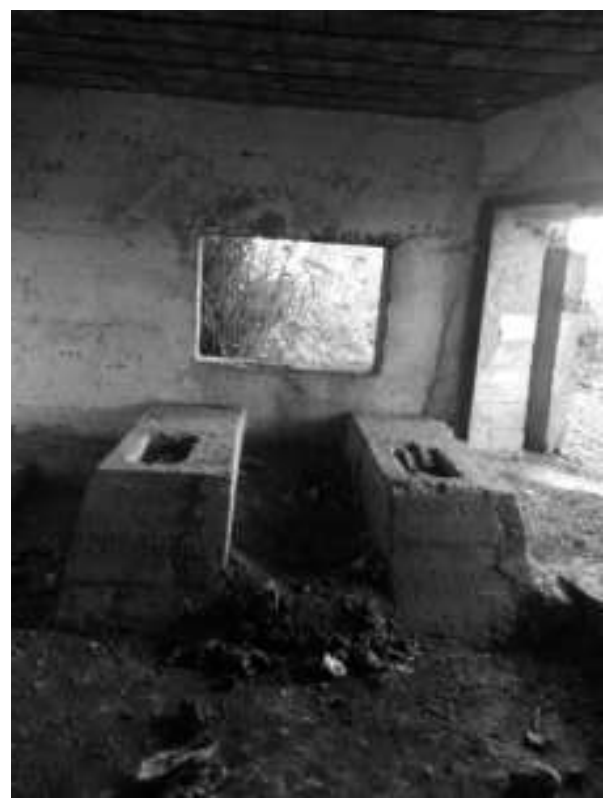

Ek 15 1. Üçüncü tip koruganda topların yerleştirildiği düzenek ve pencere.

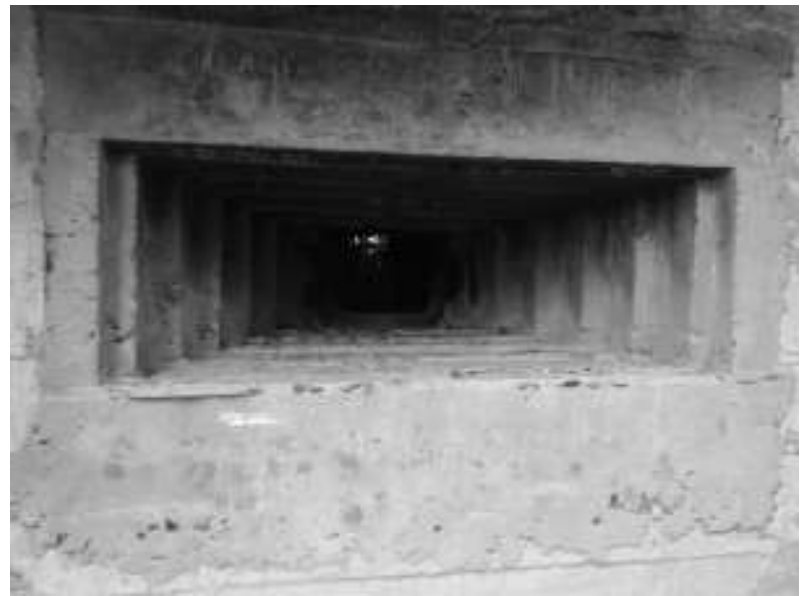

Ek 15. m. Üçüncü tip koruganların duvar kalınlığı hakkında bilgi veren pencere. 
İkinci Dünya Savaşı'nda Kıyı ve İç Hat Savunması:

Çakmak Hattı (Büyükçekmece-Çatalca) Koruganları

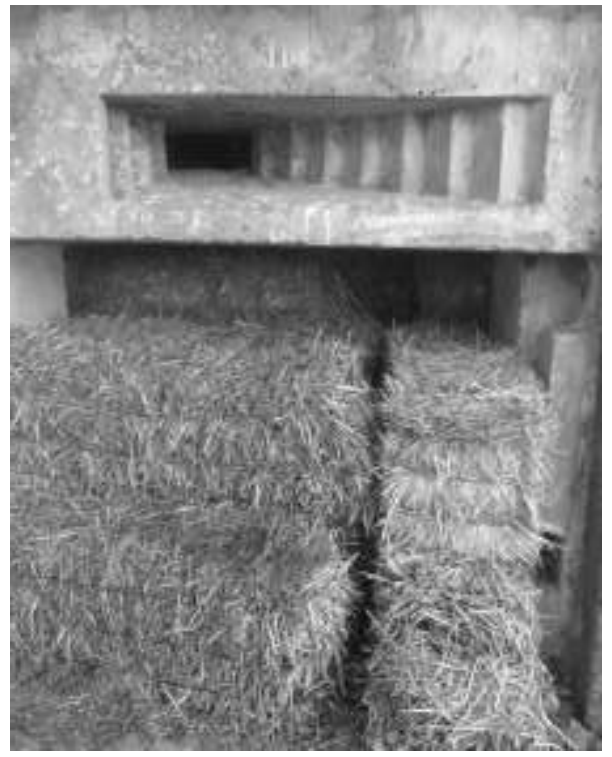

Güvenlik

Stratejileri

Cilt: 16

Say1: 34

Ek 15. n. Çatalca Dağyenice Köyü. Üçüncü tip korugan samanlık deposu olarak kullanılmaktadır. Topların korugan içerisine sokulduğu kapının üst tarafinda makinalı tüfeklerin atış yönünü gösteren pencere.

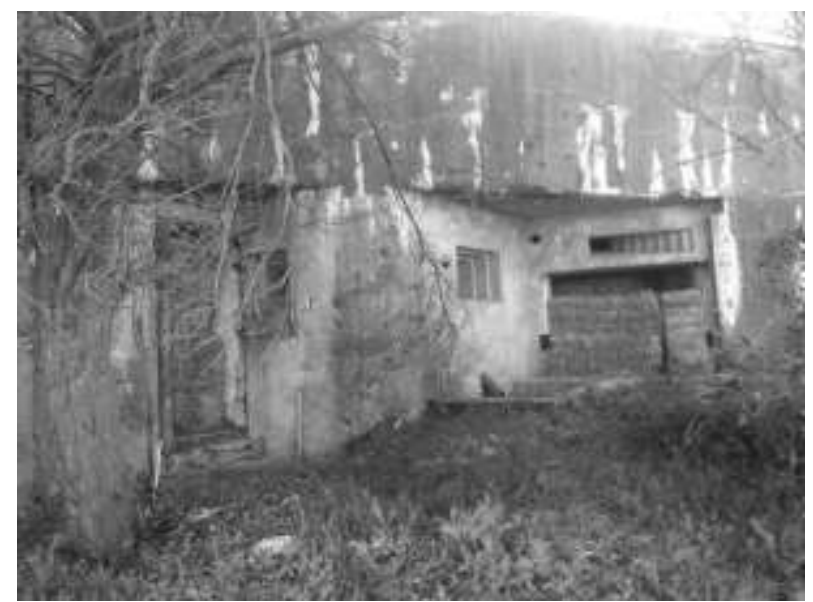

Ek 15. o. Çatalca Dağyenice Köyü, samanlık olarak kullanılan üçüncü tip korugan. 


\section{Salim AYDIN}

\section{4}

Güvenlik

Stratejileri

Cilt: 16

Sayı: 34

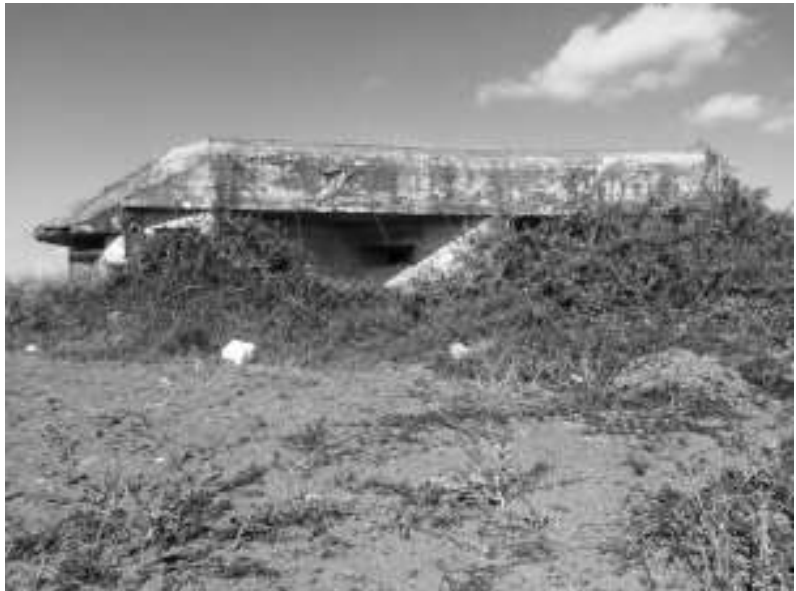

Ek 16. a. Büyükçekmece-Eskice Çiftliği yolu sol tarafta dördüncü tip koruganın yandan görünümü.

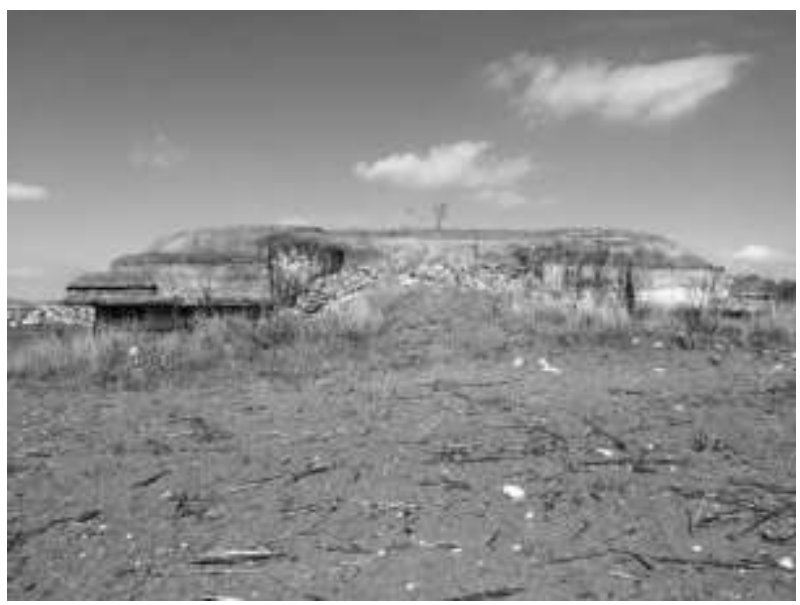

Ek 16. b. Dördüncü tip, koruganların önden görünümü. 
İkinci Dünya Savaşı'nda Kıyı ve İç Hat Savunması:

Çakmak Hattı (Büyükçekmece-Çatalca) Koruganları

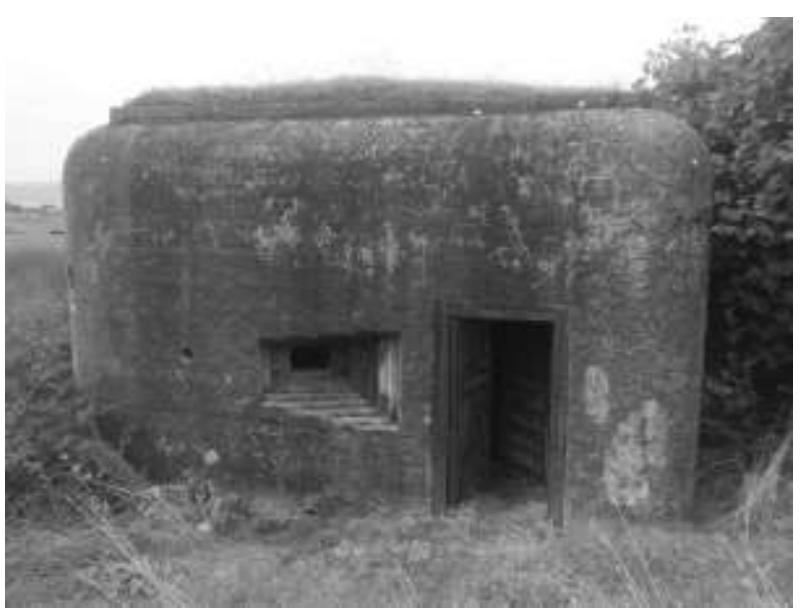

435

Güvenlik

Stratejileri

Cilt: 16

Say1: 34

Ek 16. c. Dördüncü tip koruganın arka giriş kapısı.

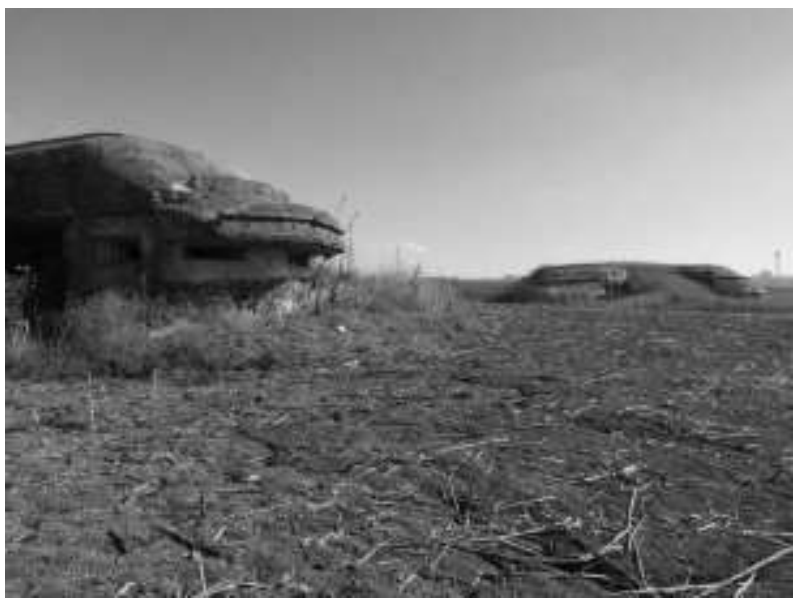

Ek 16. d. İki tane dördüncü tip korugan yanyana. 


\section{Salim AYDIN}

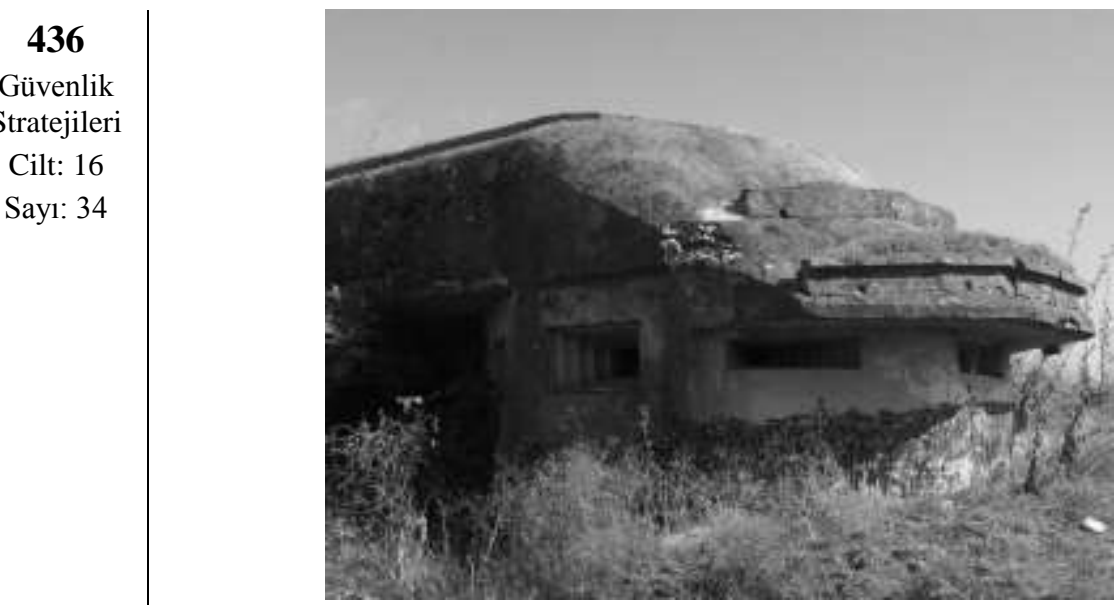

Ek 16. e. Dördüncü tip koruganın sağ tarafi.

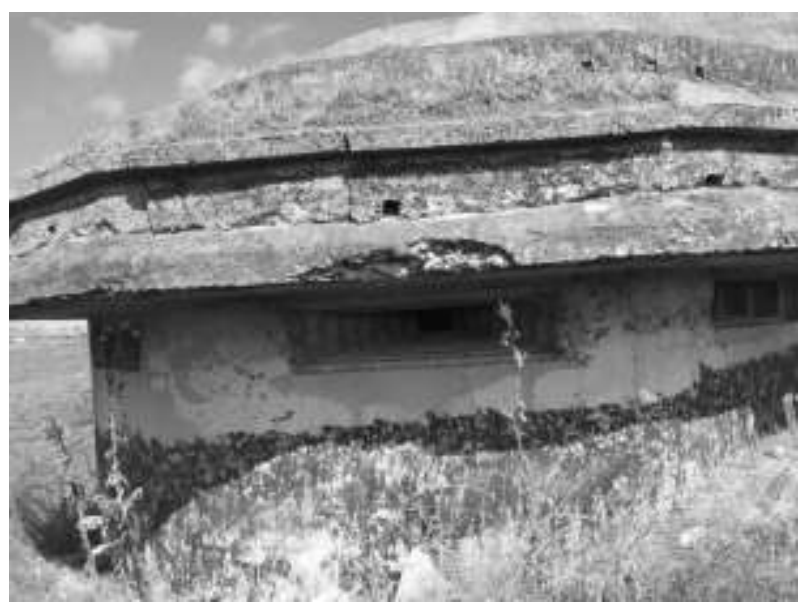

Ek 16. f. Dördüncü tip sağ kanadın sol yüzü. 
İkinci Dünya Savaşı'nda Kıyı ve İç Hat Savunması: Çakmak Hattı (Büyükçekmece-Çatalca) Koruganları

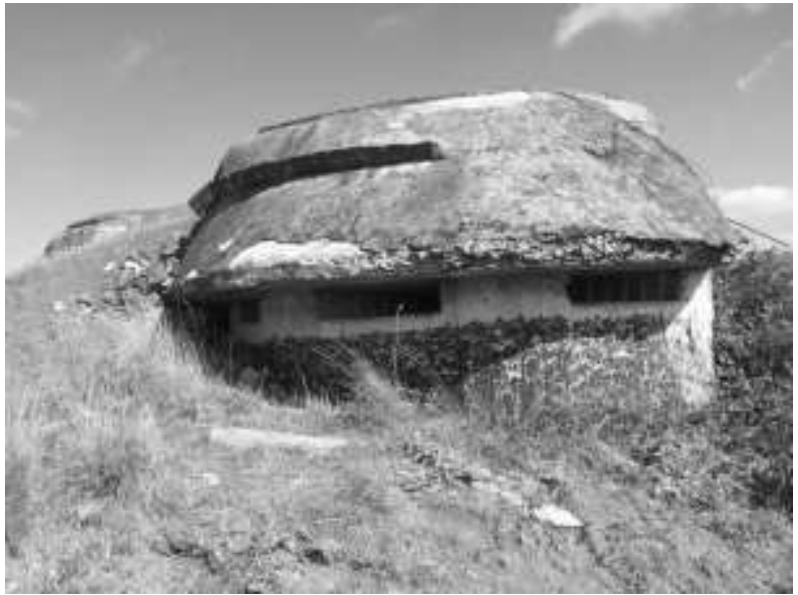

Güvenlik

Stratejileri

Cilt: 16

Say1: 34

Ek 16. g. Dördüncü tip sol ön.

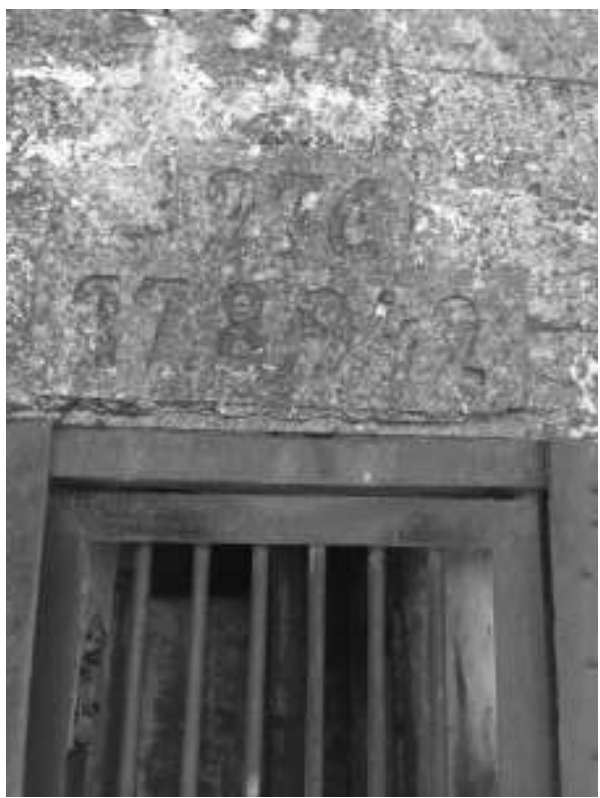

Ek 16. h. Dördüncü tip korugan, 17.08.1942 tarihinde yapılmış 276. korugandir. 


\section{Salim AYDIN}

\section{8}

Güvenlik Stratejileri

Cilt: 16

Sayı: 34

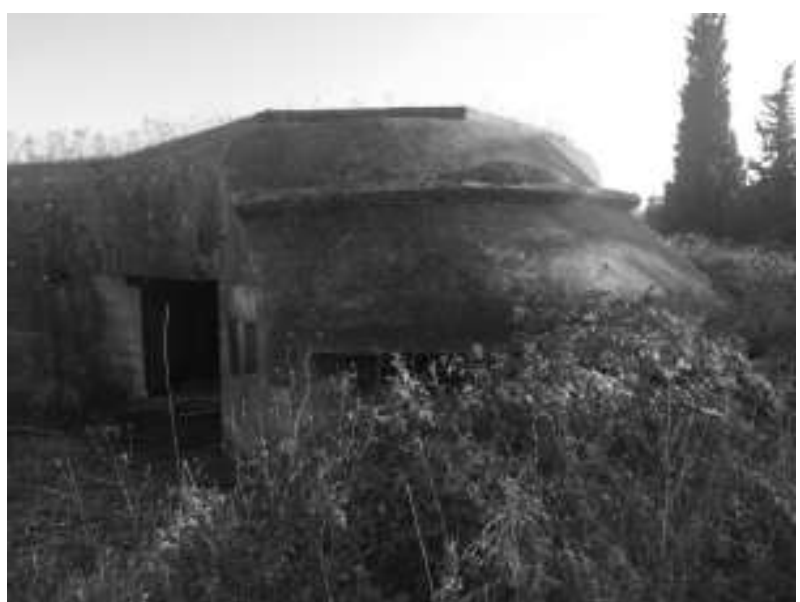

Ek 16. 1. Topların içeriye alındığı yan kapı ve sağ kanat ön cephe.

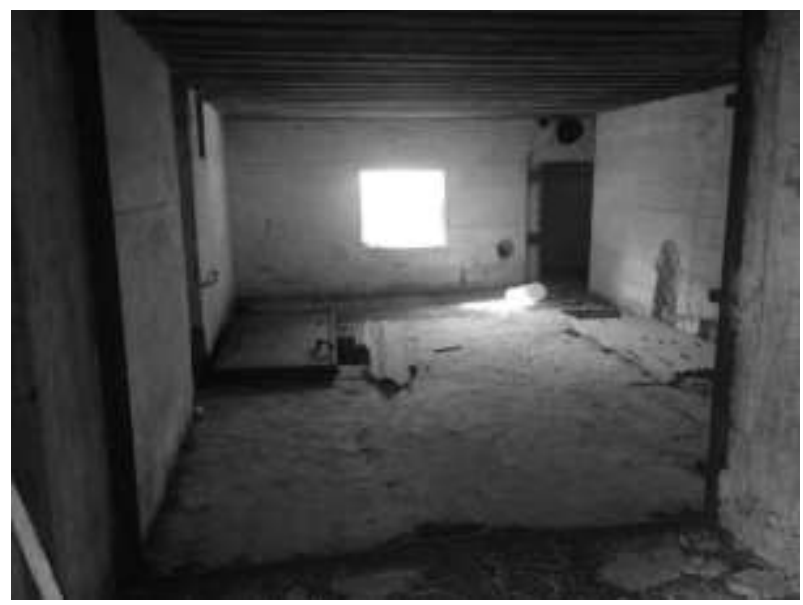

Ek 16. i. Dördüncü tip korugan topların yerleştirildiği kapıdan koruganın içi. Solda sığınağa inilen kısım. 
İkinci Dünya Savaşı'nda Kıyı ve İç Hat Savunması:

Çakmak Hattı (Büyükçekmece-Çatalca) Koruganları

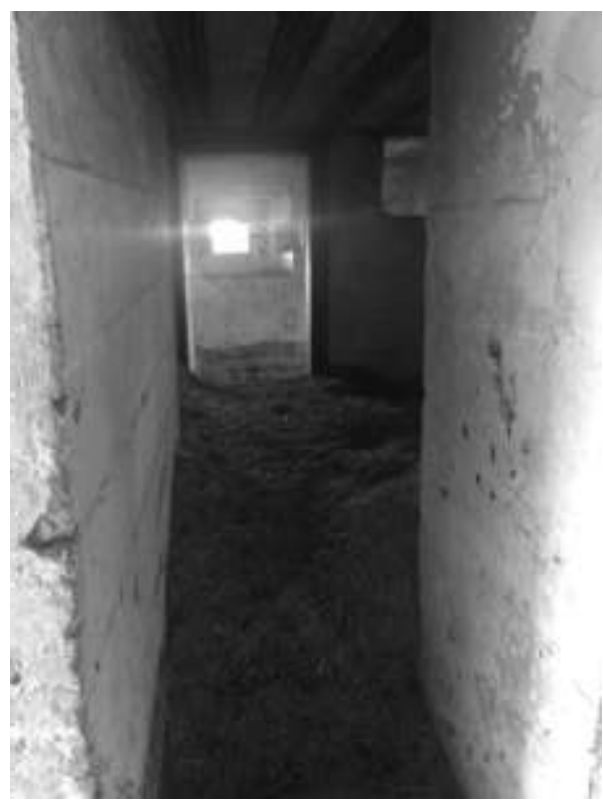

\section{9}

Güvenlik

Stratejileri

Cilt: 16

Say1: 34

Ek 16. j. Dördüncü tip koruganlarda kanatlara açılan koridor.

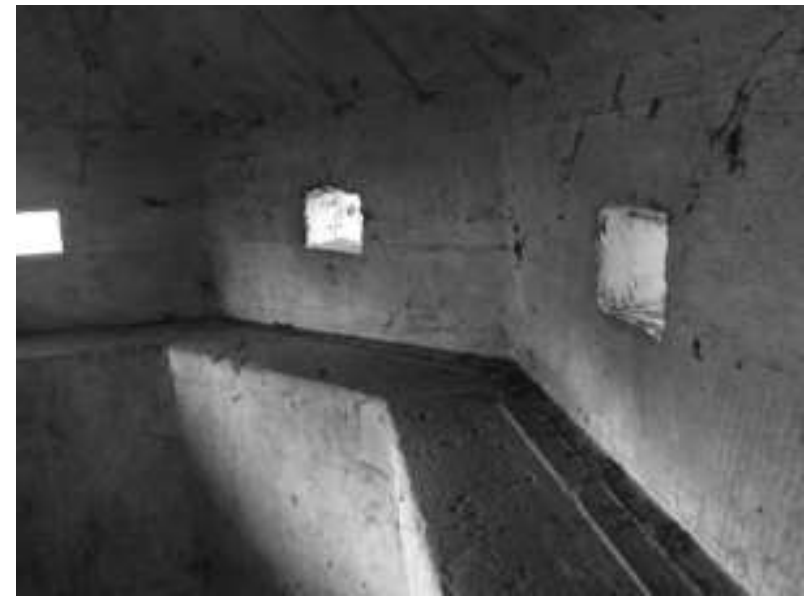

Ek 16. k. Dördüncü tip koruganın sağ ve sol kanatlarında yukarıdaki gibi makinalı tüfeklerle atış yapılan pencerelerin içeriden görünümü. 


\section{Salim AYDIN}

\section{0}

Güvenlik Stratejileri

Cilt: 16

Sayı: 34

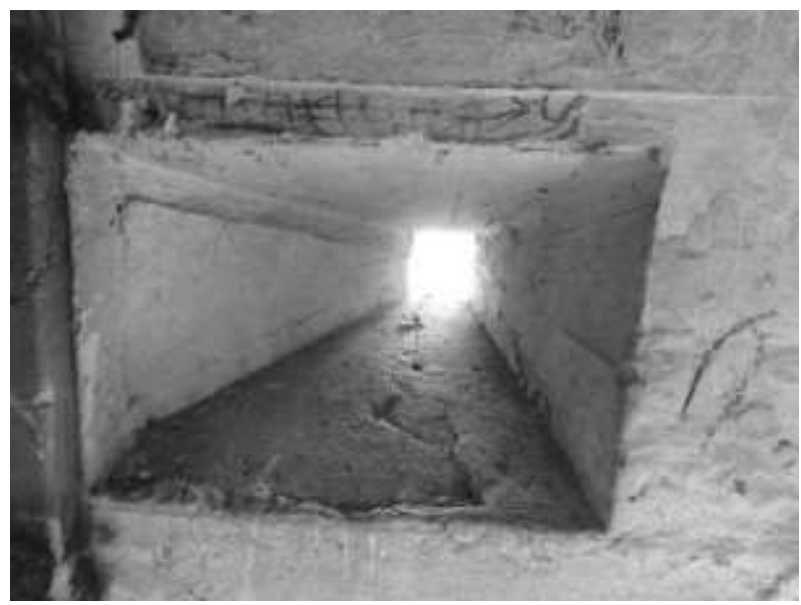

Ek 16. 1. Dördüncü tip koruganda içerden dışarıya doğru daralan atış penceresi.

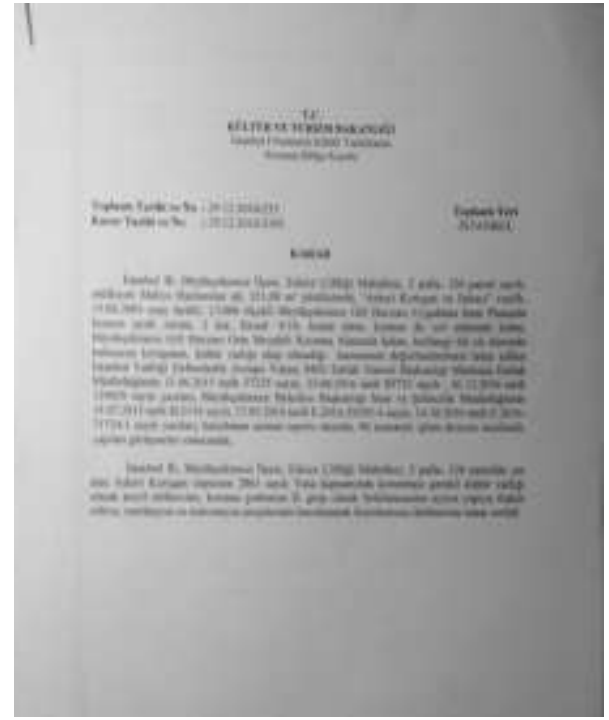

Ek 17. a. Büyükçekmece Eskice Çiftliği köy merkezinde bulunan dördüncü tip koruganın tescil belgesi. 
İkinci Dünya Savaşı'nda Kıyı ve İç Hat Savunması:

Çakmak Hattı (Büyükçekmece-Çatalca) Koruganları

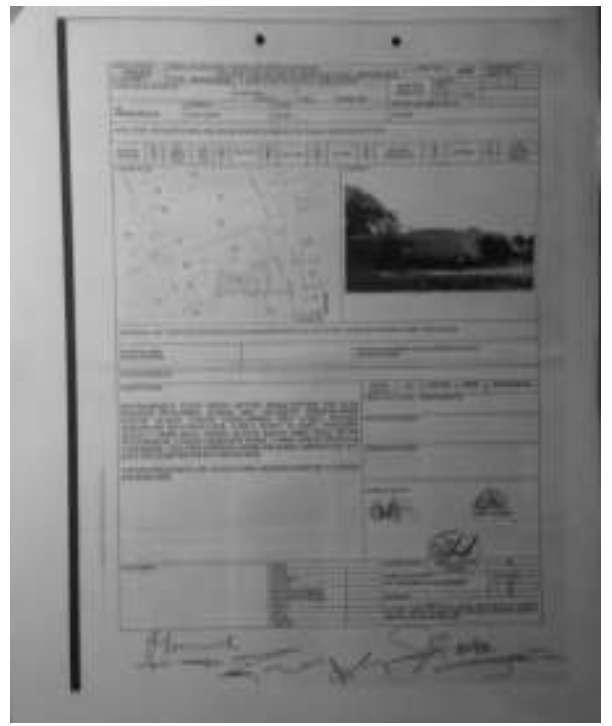

\section{1}

Güvenlik

Stratejileri

Cilt: 16

Say1: 34

Ek 17. b. Koruganın yerini gösterir pafta.

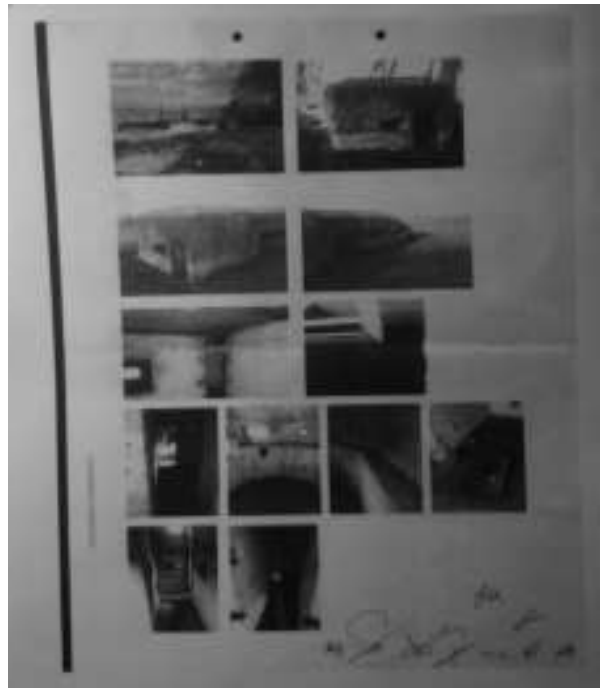

Ek 17. c. Koruganın içten ve dıștan fotoğrafları 


\section{Salim AYDIN}

\section{2}

Güvenlik

Stratejileri

Cilt: 16

Sayı: 34

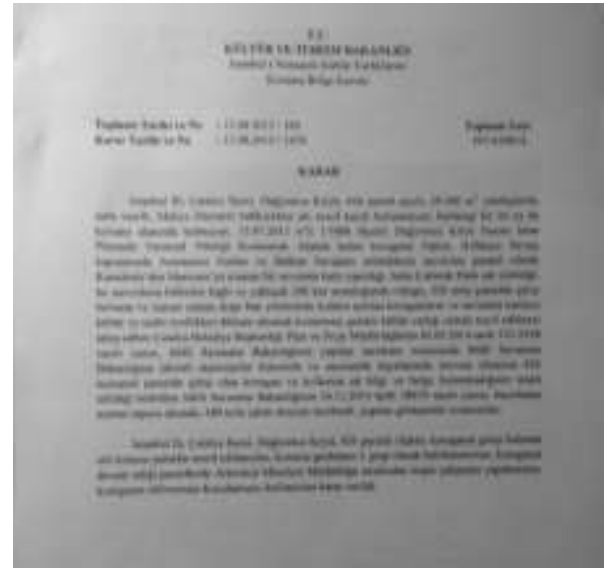

Ek 18. a. Çakmak Hattı'ndaki en büyük koruganın tescil belgesi, Avrupalıların blockhouse adını verdiği, Osmanlı Devleti'nde tabya sistemine benzeyen toprak altında yapılan savunma alanıdır. Bu büyük korugandan Çakmak Hattı'nda bir tane tespit edilmiştir. Bu korugandaki tünellerin üçüncü tip koruganlarla bağlantısı vardır.

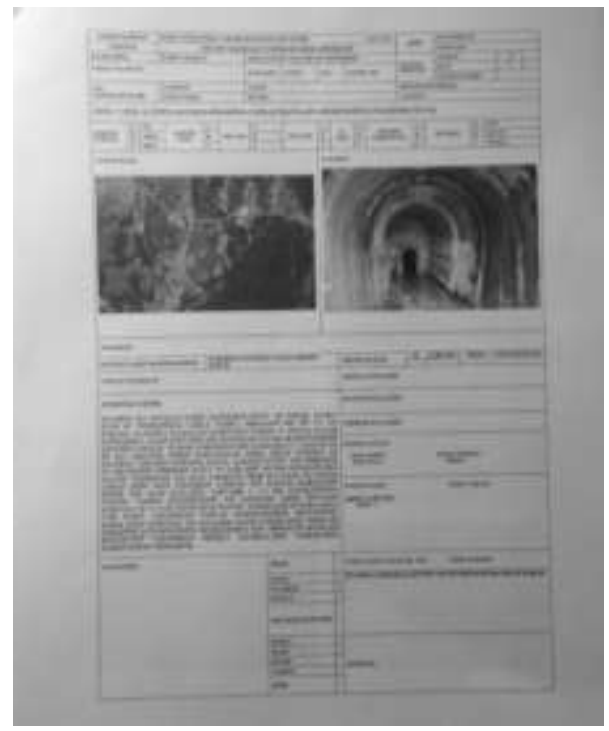

Ek 18. b. En büyük koruganın yeri ve pafta numarası. 
İkinci Dünya Savaşı'nda Kıyı ve İç Hat Savunması:

Çakmak Hattı (Büyükçekmece-Çatalca) Koruganları

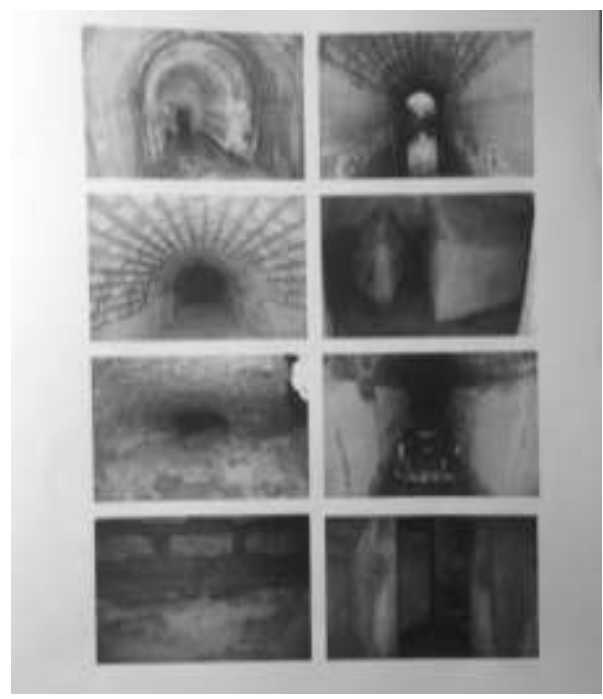

443

Güvenlik

Stratejileri

Cilt: 16

Say1: 34

Ek 18. c. En büyük koruganın dıştan ve içten fotoğrafları.

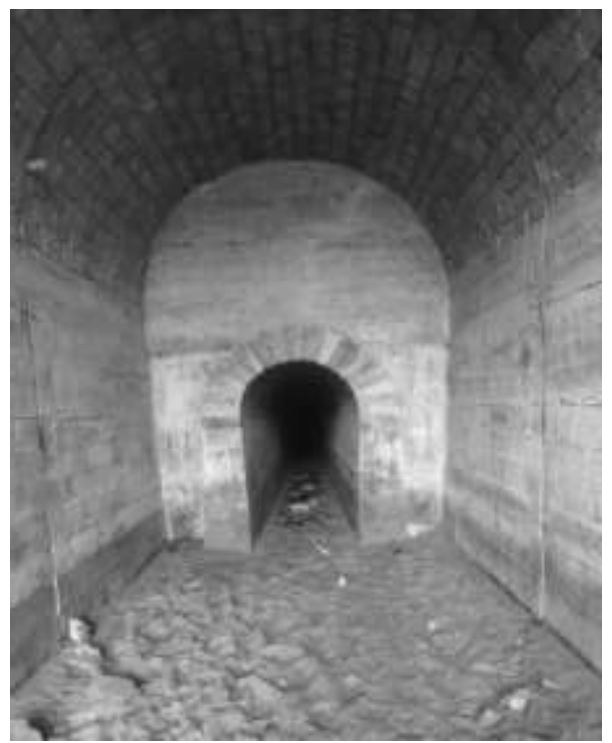

Ek 18. d. Çatalca Dağyenice Köyü en büyük koruganın giriş tüneli. 


\section{Salim AYDIN}

\section{4}

Güvenlik

Stratejileri

Cilt: 16

Sayı: 34

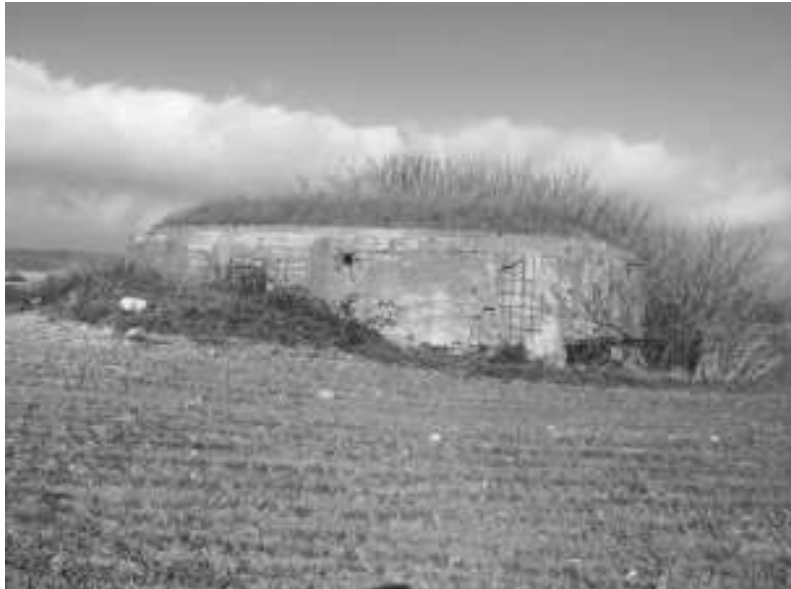

Ek 18. e. Çatalca Dağyenice Köyü Çakmak Hattı tünelle bağlantısı olan üçüncü tip koruganlardan birisi.

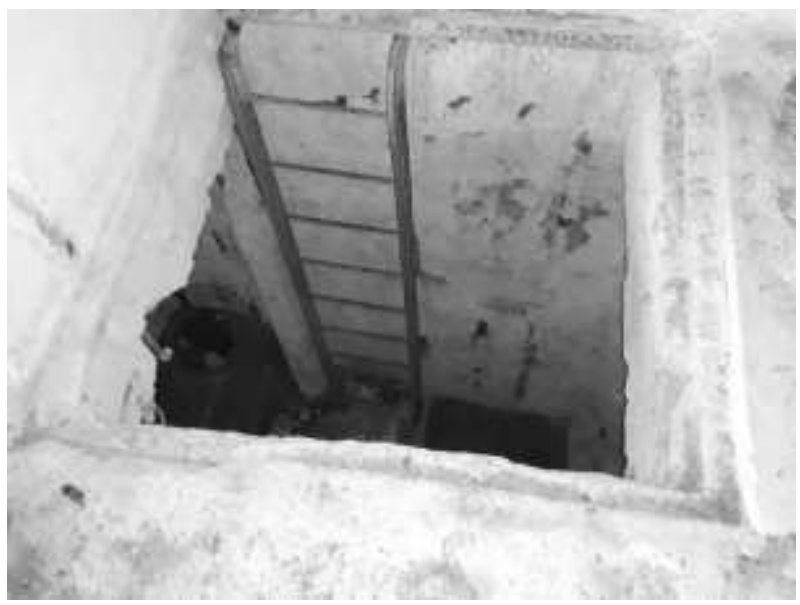

Ek 18. f. Çatalca Dağyenice Köyü, yukarıdaki fotoğrafta (Ek 18.d.) görünen tünel girişinden yaklaşık 300 metre ileride üçüncü tip koruganın zemin katının altında sığınak ve sığınağın altından tünele bağlanan kare biçiminde yapılmış mühimmat geçiş bağlantı noktası vardır. 
İkinci Dünya Savaşı'nda Kıyı ve İç Hat Savunması:

Çakmak Hattı (Büyükçekmece-Çatalca) Koruganları

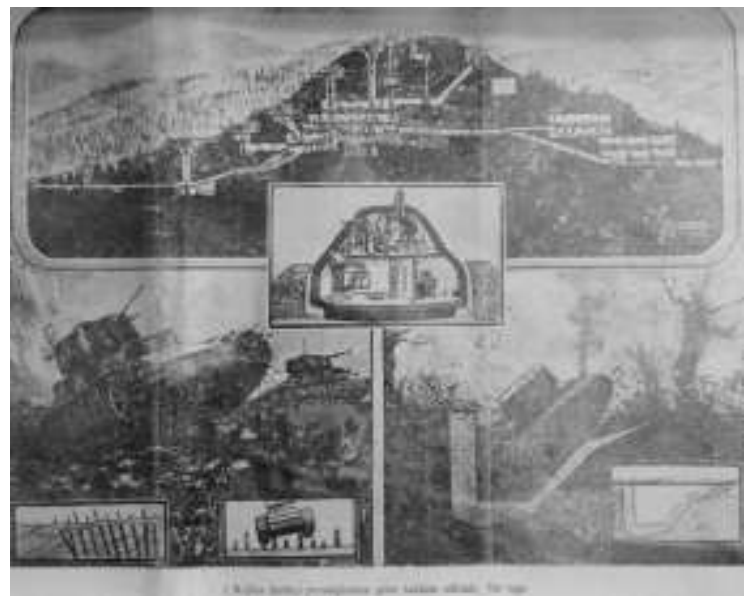

\section{5}

Güvenlik

Stratejileri

Cilt: 16

Say1: 34

Ek 18. g. Majino Hatt1. Kaynak Hamdi Turgay, a.g.m. s. 566.

Majino Hattındaki bu sistem ile Çatalca Dağyenice Köyünde kurulan korugan sistemi büyük bir benzerlik göstermektedir.

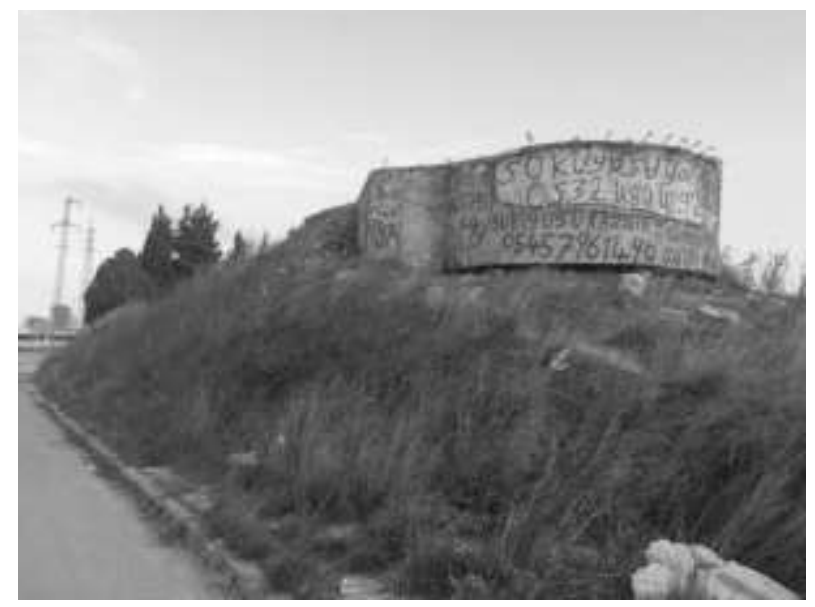

Ek 19. a. Altıncı tip korugan örneği, Büyükçekmece Gölü’nün sona erdiği Karaağaç Köyü'ne en hakim tepede Alkent, Yiğittürk Caddesi ile Sırtköy Bulvarının birleştiği noktada Kültür 2000 Koleji ile İstanbul Üniversitesi-Cerrahpaşa Teknik Bilimler Meslek Yüksek Okulu arasındadır. Koruganın yandan görünümü. 


\section{Salim AYDIN}

\section{6}

Güvenlik

Stratejileri

Cilt: 16

Sayı: 34

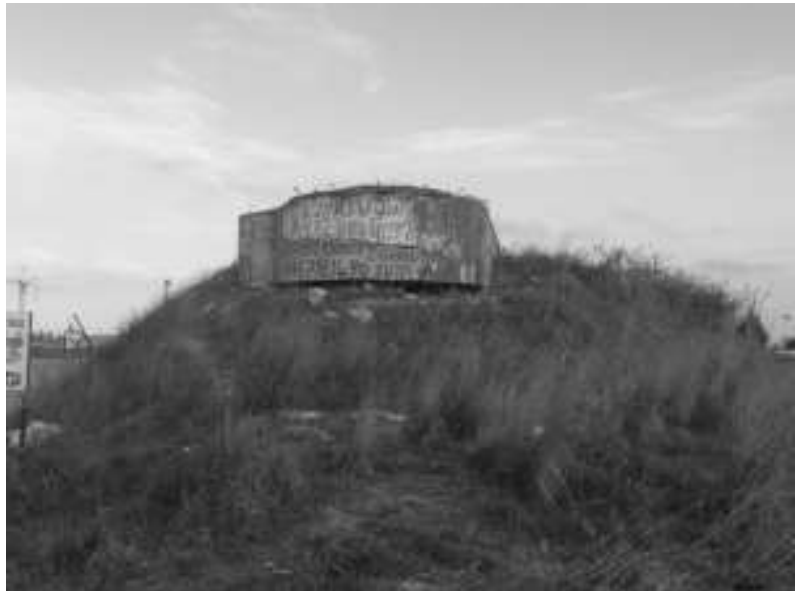

Ek 19. b. Altıncı tip korugan önden görünüm. Büyükçekmece Alkent, Yiğittürk Caddesi ile Sırtköy Bulvarının birleştiği noktada Kültür 2000 Koleji ile İstanbul Üniversitesi-Cerrahpaşa Teknik Bilimler Meslek Yüksek Okulu arasındadır. Koruganın önden görünümü.

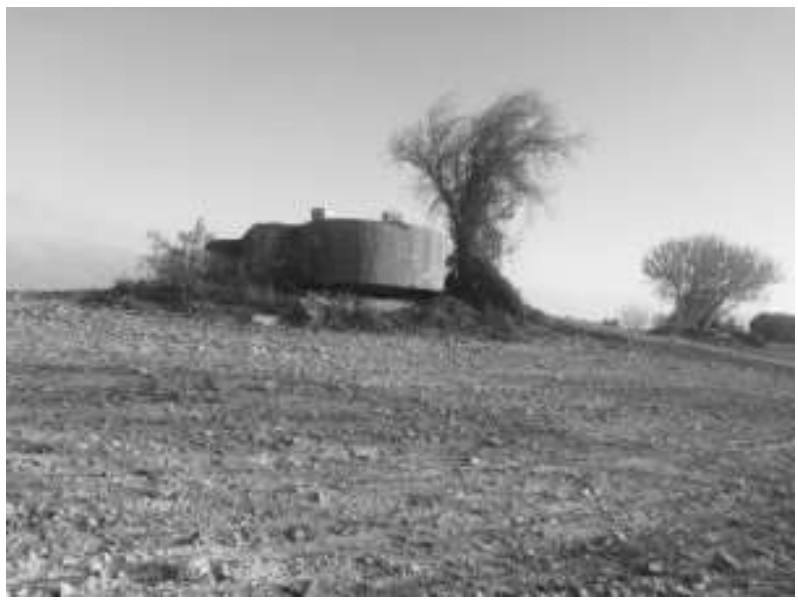

Ek 20. a. Altıncı tip korugan, Terkos (Durusu) Gölü’nün sona erdiği, Yazlık Köyü ile Terkos Gölü’ne en hâkim tepededir. 
İkinci Dünya Savaşı'nda Kıyı ve İç Hat Savunması:

Çakmak Hattı (Büyükçekmece-Çatalca) Koruganları

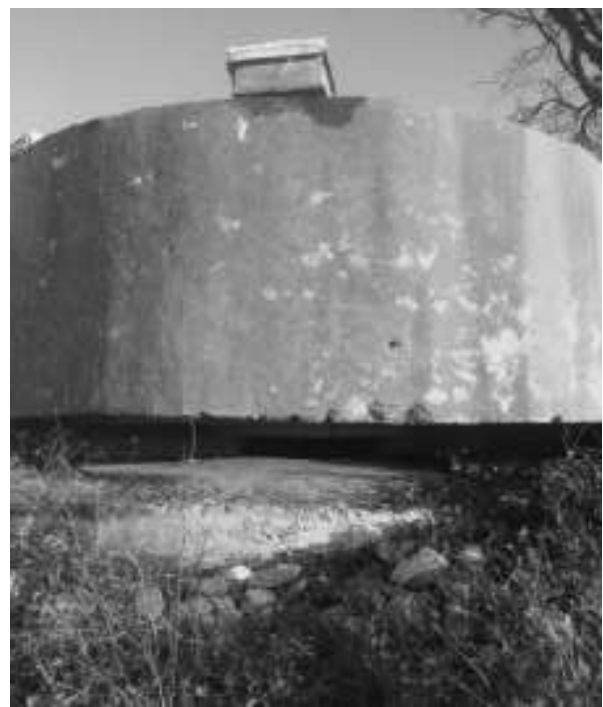

\section{7}

Güvenlik

Stratejileri

Cilt: 16

Say1: 34

Ek 20. b. Altınc1 tip korugan, atış yapılan pencere, önden görünüm. Terkos (Durusu) Gölü'nün sona erdiği, Yazlık Köyü ile Terkos Gölü’ne en hâkim tepede.

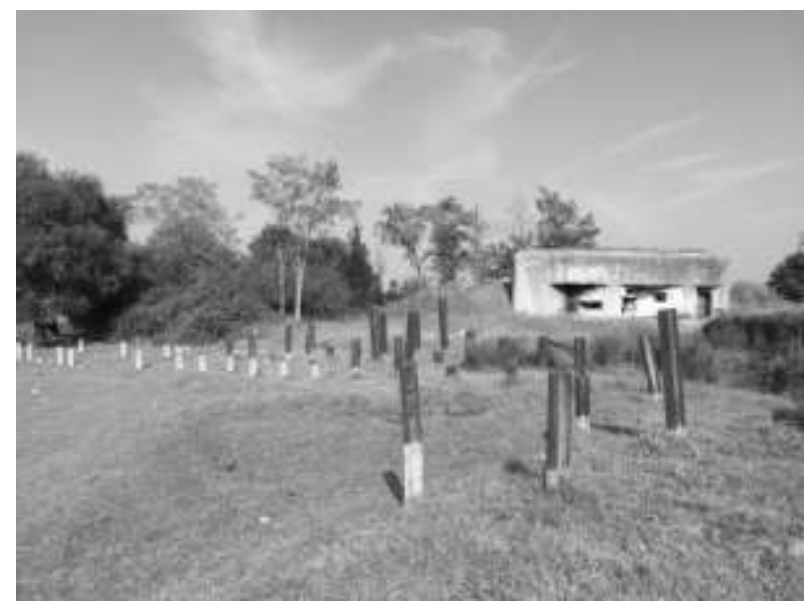

Ek 21. a. Çatalca Bahşiyiş Köyü Korugan önünde birçoğu kesilmiş ejderişleri. 


\section{Salim AYDIN}

\section{8}

Güvenlik

Stratejileri

Cilt: 16

Sayı: 34

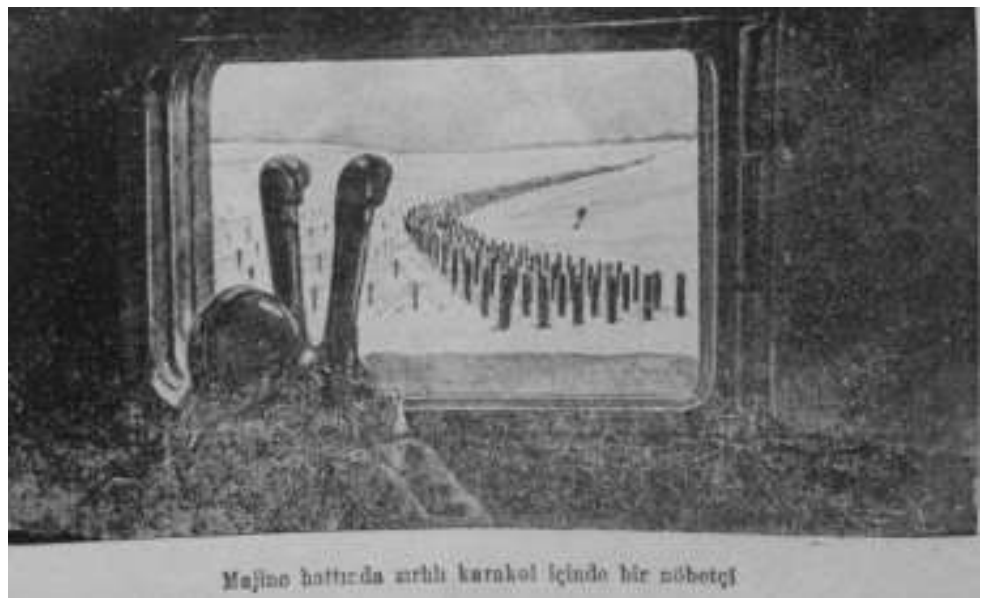

Ek 21. b. Kaynak Hamdi Turgay, a.g.m. s. 562. Majino Hatt1 korugan içerisinden ejderdişleri.

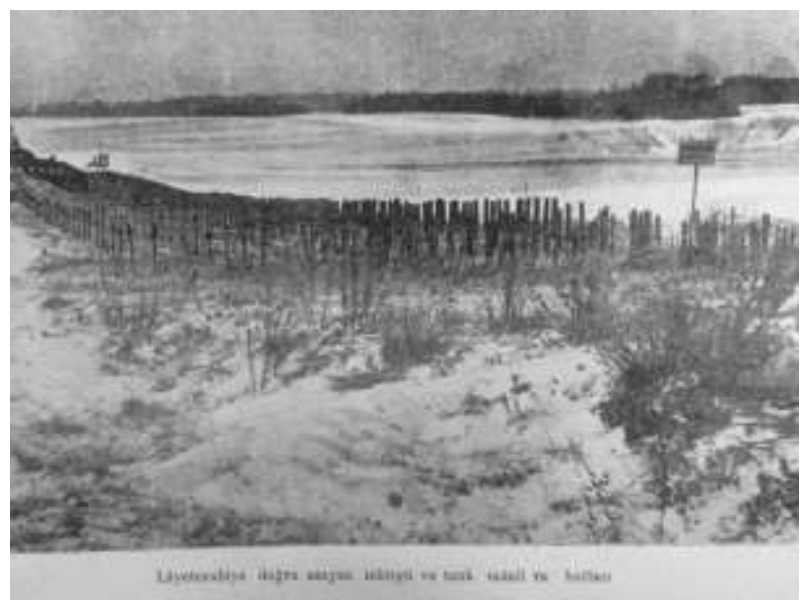

Ek 21. c. Majino Hattı ray demirlerinden yapılmış ejder dişleri. Kaynak Hamdi Turgay, a.g.m. s. 564. 
İkinci Dünya Savaşı'nda Kıyı ve İç Hat Savunması:

Çakmak Hattı (Büyükçekmece-Çatalca) Koruganları

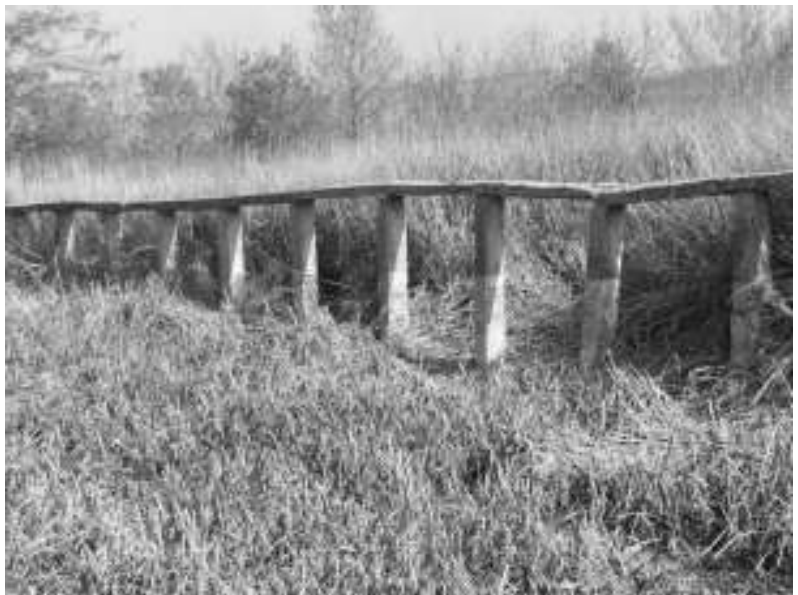

Güvenlik

Stratejileri

Cilt: 16

Say1: 34

Ek 21. d. Bahşiyiş Köyü tankların geçişini engellemek için içinde demir bulunan birbirlerine bağlı ejderdişleri. Daha önce bu ejderdişlerinin önünde derin kazılmış bir hendek vardı. Ancak zamanla bu hendek dolduruldu.

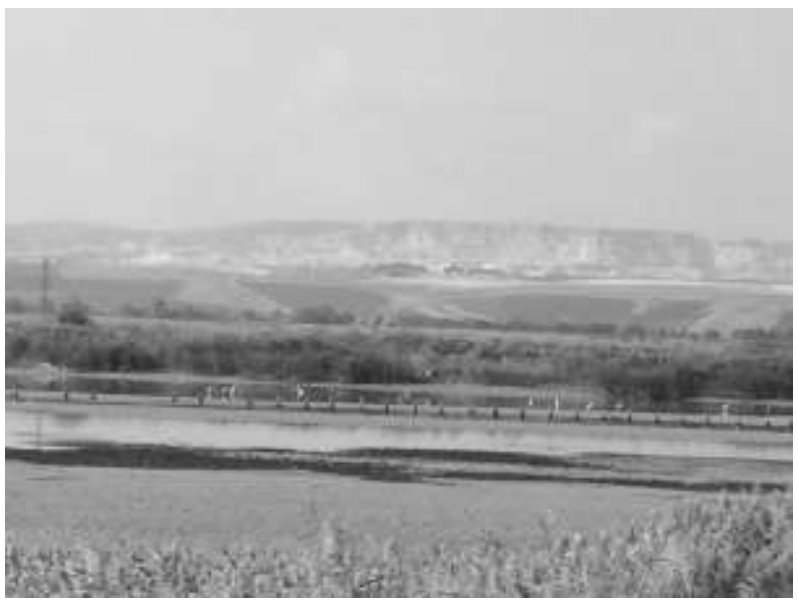

Ek 21. e. Bahşiyiş Köyü, Göl 1989 yılında baraj yapılmadan önce fotoğrafta görülen kısımlar tarla konumundaydı. Baraj yapıldıktan sonra ejderdişlerinin bir kısmı baraj içerisinde kalmış, bir kısmı da göl ıslah çalışmaları yapılırken sökülüp atılmıştır. 


\section{Salim AYDIN}

\section{0}

Güvenlik

Stratejileri

Cilt: 16

Sayı: 34

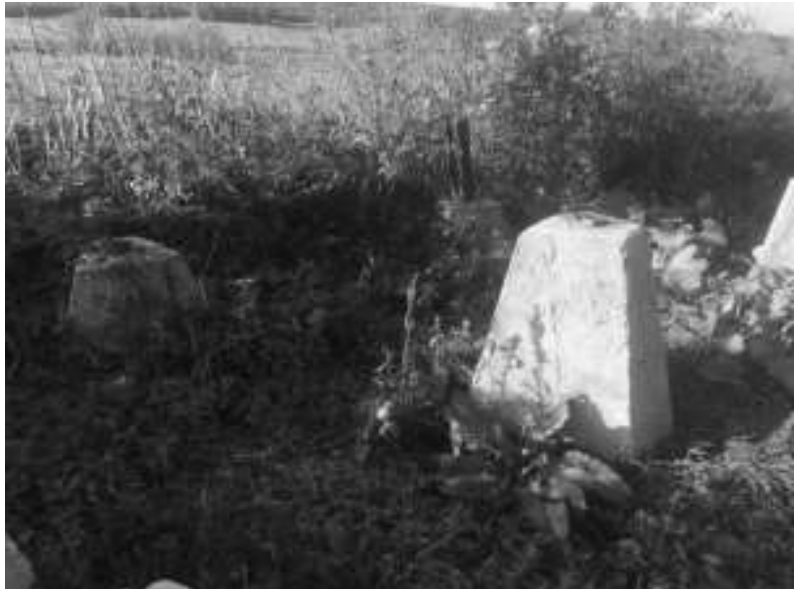

Ek 22. a. Korugan ve ejderdişlerinin yoğun olarak yapıldığı yerlerden birisi

Terkos (Durusu) Gölü’nün Çatalca'ya doğru sona erdiği nokta olan

Yazlık (Lazarköy) Köydür. Burada betondan yapılan ejderdişlerinin uzunluğu yaklaşık bir buçuk metre civarındadır. Bu yüksekliğin yarısı toprak altındadır.

Betondan yapılan ejderdişleri çapraz iki sıra halinde yapılmış, ayrıca üstünde yaklaşık bir metre yüksekliğinde ray demirleri konularak güçlü bir set oluşturulmaya çalışılmıştır.

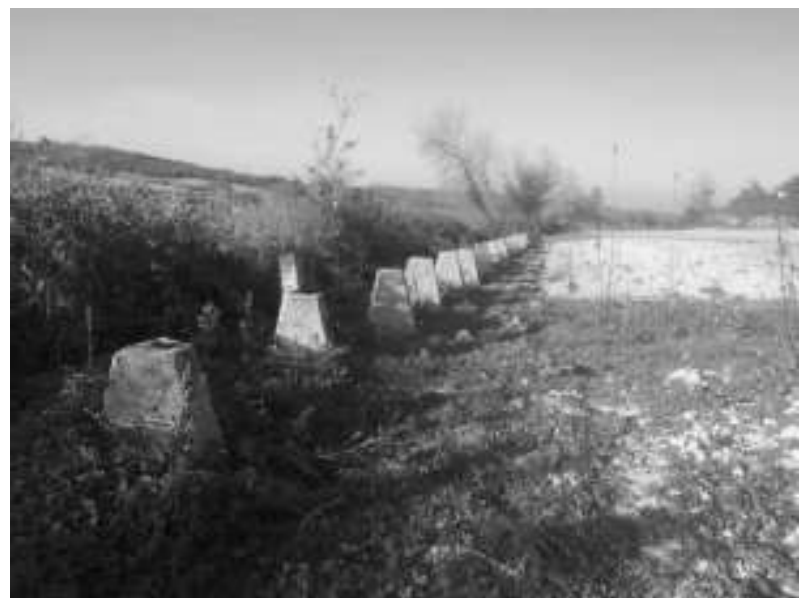

Ek 22. b. Çatalca Yazlık Köyü tek sıra halinde ejderdişleri. 
İkinci Dünya Savaşı'nda Kıyı ve İç Hat Savunması:

Çakmak Hattı (Büyükçekmece-Çatalca) Koruganları

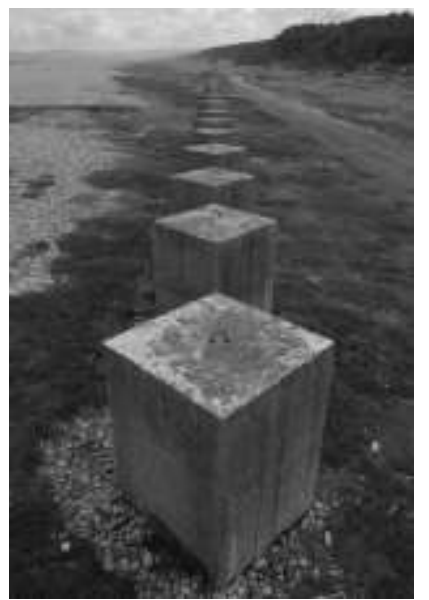

\section{1}

Güvenlik

Stratejileri

Cilt: 16

Say1: 34

Ek 23. a. Avrupa'da özellikle de Britanya'da denizlerden gelecek çıkarmalara karşı ejderdişleri çok sayıda yapılmıştır.

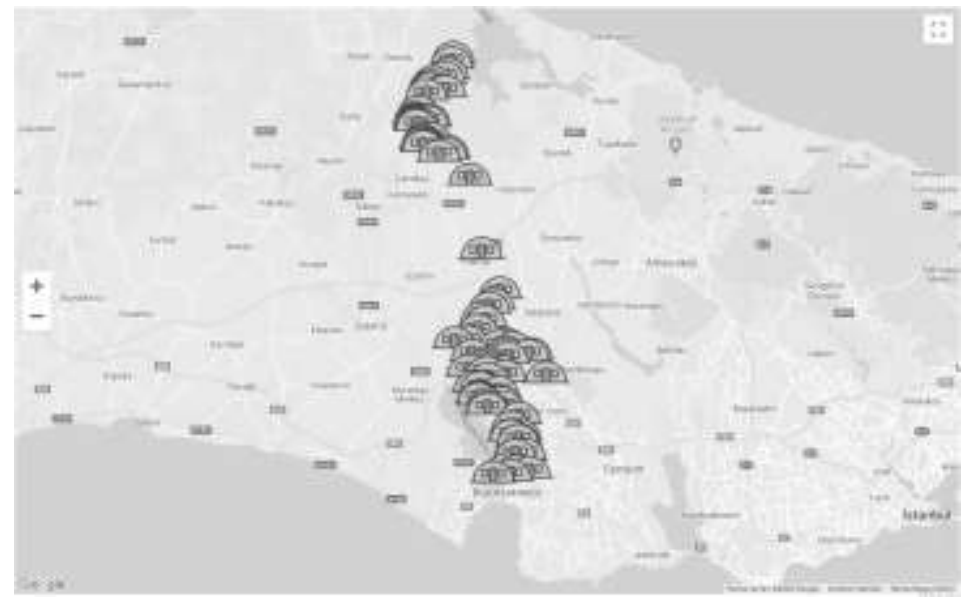

Ek 24. Çatalca-Büyükçekmece "Çakmak Hattı Koruganlarını gösterir harita" bu harita Milli Savunma Üniversitesi Fatih Harp Tarihi Araştırmaları Enstitüsü korugan araştırma ekibi tarafından koruganların yanına gidilerek konumları belirlenmiş sonra Google Haritalara işlenerek elde edilmiştir. 